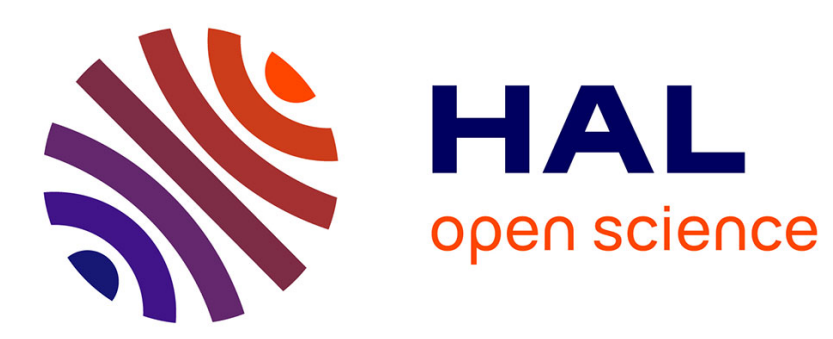

\title{
Constraints on deformation conditions and the origin of oceanic detachments: The Mid-Atlantic Ridge core complex at $15^{\circ} 45^{\prime} \mathrm{N}$
}

\author{
J. Escartin, C. Mevel, C. J. Macleod, A. M. Mccaig
}

\section{- To cite this version:}

J. Escartin, C. Mevel, C. J. Macleod, A. M. Mccaig. Constraints on deformation conditions and the origin of oceanic detachments: The Mid-Atlantic Ridge core complex at $15^{\circ} 45^{\prime} \mathrm{N}$. Geochemistry, Geophysics, Geosystems, 2003, 4 (8), 10.1029/2002gc000472 . insu-01874749

HAL Id: insu-01874749

https://hal-insu.archives-ouvertes.fr/insu-01874749

Submitted on 14 Sep 2018

HAL is a multi-disciplinary open access archive for the deposit and dissemination of scientific research documents, whether they are published or not. The documents may come from teaching and research institutions in France or abroad, or from public or private research centers.
L'archive ouverte pluridisciplinaire $\mathbf{H A L}$, est destinée au dépôt et à la diffusion de documents scientifiques de niveau recherche, publiés ou non, émanant des établissements d'enseignement et de recherche français ou étrangers, des laboratoires publics ou privés. 


\title{
Constraints on deformation conditions and the origin of oceanic detachments: The Mid-Atlantic Ridge core complex at $15^{\circ} 45^{\prime} \mathrm{N}$
}

\author{
J. Escartín and C. Mével \\ Laboratoire de Géosciences Marines (CNRS UMR7097), Institut de Physique du Globe, 75252 Paris, France \\ (escartin@ipgp.jussieu.fr; mevel@ipgp.jussieu.fr)
}

\author{
C. J. MacLeod \\ Cardiff School of Earth, Ocean and Planetary Sciences, Cardiff University, Cardiff CF10 3YE, UK (macleod@cf.ac.uk)
}

\author{
A. M. McCaig \\ School of Earth Sciences, University of Leeds, Leeds LS2 9JT, UK (andrew@earth.leeds.ac.uk)
}

[1] Deformed rocks sampled from a corrugated detachment fault surface near the Mid-Atlantic Ridge $\left(15^{\circ} 45^{\prime} \mathrm{N}\right)$ constrain the conditions of deformation and strain localization. Samples recovered in situ record deformation restricted to the cold (shallow) lithosphere (greenschist facies), with no evidence for significant high-temperature deformation either at the fault zone or in the footwall near it. High-temperature deformation $\left(\sim 720-750^{\circ} \mathrm{C}\right)$ is observed only at two sites, and cannot be directly linked to the detachment. Detachment faulting was coeval with dyke intrusions that cross cut it, as demonstrated by the presence of undeformed and highly deformed diabase found in shear zones, and by the presence of chill margins in diabase against fault rock. Basalts are very scarce and restricted to clasts in breccias, with no evidence of pillows or extrusive structures. Gabbros crop out along mass-wasted and fault scarps structurally below the detachment. Footwall rocks show little or no deformation, due to strain localization along a narrow shear zone $(<200 \mathrm{~m})$ with fluid flow, as required to form talc- and amphibole schists after an ultramafic protolith. We speculate that the alteration front in a heterogeneous lithosphere may be a rheological boundary that may localize deformation during long periods of time. Our observations and other geological evidence elsewhere suggest that this detachment model limited to the cold (shallow) lithosphere is applicable to other corrugated surfaces along slow- and intermediate-spreading ridges. These observations preclude detachment models rooting in melt-rich zones (i.e., Atlantis Bank, Southwest Indian Ridge) or recording high-temperature deformation. We infer that oceanic detachment faults (1) localize strain at $\mathrm{T}<500-300^{\circ} \mathrm{C}$, (2) persist during active magmatism, and (3) root at shallow rheological boundaries, such as a melt-rich zone or magma chamber ("hot" detachments) or an alteration front ("cold" detachments).

Components: 19,237 words, 16 figures, 7 tables.

Keywords: Faulting; mid-ocean ridge; detachment; rheology.

Index Terms: 8010 Structural Geology: Fractures and faults; 8159 Tectonophysics: Rheology—crust and lithosphere; 3035 Marine Geology and Geophysics: Midocean ridge processes.

Received 6 November 2002; Revised 12 April 2003; Accepted 17 April 2003; Published 7 August 2003.

Escartín, J., C. Mével, C. J. MacLeod, and A. M. McCaig, Constraints on deformation conditions and the origin of oceanic detachments: The Mid-Atlantic Ridge core complex at $15^{\circ} 45^{\prime} \mathrm{N}$, Geochem. Geophys. Geosyst., 4(8), 1067, doi:10.1029/ 2002GC000472, 2003. 


\section{Introduction and Background}

[2] Numerous structures interpreted as oceanic low-angle normal faults (detachments) have been identified along slow- and intermediate spreading mid-oceanic ridges in recent years. Morphologically, these structures are characterized by continuous surfaces on which prominent striations parallel to the spreading direction are observed at wavelengths of $>1 \mathrm{~km}$ to $<100 \mathrm{~m}$ [e.g., Cann et al., 1997; Christie et al., 1997; Casey et al., 1998; Deplus et al., 1998; Martinez et al., 1998; Mitchell et al., 1998; Tamaki et al., 1998; Tucholke et al., 1998, 2001; Searle et al., 1999; Escartín and Cannat, 1999; Ranero and Reston, 1999; MacLeod et al., 2002; Reston et al., 2002]. They are often domal in form, dipping shallowly $\left(<20^{\circ}\right)$ toward the axis near the ridge, curving to become sub-horizontal or dipping gently away from the axis. Samples recovered from the striated surfaces include serpentinized peridotite and gabbro, in addition to basalt and diabase [e.g., Cann et al., 1997; Escartín et al., 1999; Tucholke et al., 2001], suggesting that the structures can be responsible for denuding deep lithospheric levels. Recovery of highly deformed in situ rocks from the striated surfaces confirms the supposition that they represent low-angle faults [MacLeod et al., 2002]. Positive gravity anomalies [Blackman et al., 1998] and high seismic velocities at $<1 \mathrm{~km}$ below the seafloor [Collins and Detrick, 1998] suggest that, in some cases at least, the geophysically defined crust is very thin due to tectonic unroofing along detachments.

[3] Models of continental detachment faults [e.g., Wernicke, 1981; Davis, 1983] have been used as a base to interpret these oceanic "core complexes" [Tucholke et al., 1998]. The size of the structures, the inferred geometry of the detachment surface, the length (longevity) of the faults, or the exposures of rocks from deep lithospheric levels are common to both oceanic and continental core complexes. The root of continental detachments is commonly placed within or near the top of a ductile layer [e.g., Wernicke, 1981; Lister et al., 1984; Anderson et al., 1988; Lister and Baldwin, 1993]. Similarly, it has been proposed that oceanic detachments root either at the brittle-ductile tran- sition immediately below the surface expression of the ridge axis [e.g., Tucholke et al., 1998, 2001], or in a melt-rich zone near the dyke-gabbro transition [Dick et al., 1991, 2000]. Seismic profiles over detachment faults in old oceanic crust image reflectors reaching maximum depths of $<3 \mathrm{~km}$ below basement [Ranero and Reston, 1999], but their continuity or geometry at deeper levels is unknown. The presence of rubble and/or sediments over most of these detachments [e.g., Searle et al., 1999; Kelley et al., 2001; Tucholke et al., 2001; Schroeder et al., 2002] has prevented detailed in situ sampling of the associated fault rocks, except in the case of Atlantis Bank at the Southwest Indian Ridge [e.g., Robinson et al., 1989; MacLeod et al., 1998; Dick et al., 1999, 2002].

[4] In this paper we present geological, petrological and microstructural observations, together with geochemical analyses of fault rocks sampled along an off-axis striated surface north of the FifteenTwenty Fracture zone $\left(15^{\circ} 45^{\prime} \mathrm{N}\right.$ and $\left.46^{\circ} 55^{\prime} \mathrm{W}\right)$ along the Mid-Atlantic Ridge [Escartin and Cannat, 1999; MacLeod et al., 2002; Fujiwara et al., 2003] (Figure 1). RRS James Clark Ross cruise JR63 (April-May 2001). In an earlier paper [MacLeod et al., 2002] we presented the initial results of the cruise JR63 (April-May 2001) on board RRS James Clark Ross [MacLeod et al., 2001], during which we collected bathymetry and high-resolution acoustic backscatter imagery to constrain the tectonic structure of the area (Figure 2). The results from the study of these samples, together with other geological and tectonic observations, are contrasted with predictions inferred from existing oceanic detachment models, and with results from other oceanic detachment faults elsewhere.

\section{Experiment, Sampling, and Methods}

[5] The first part of cruise JR63 was dedicated to a complete deep-towed TOBI side-scan sonar survey of the $15^{\circ} 45^{\prime} \mathrm{N}$ detachment [MacLeod et al., 2002]. The second part of the cruise was dedicated to rock sampling using oriented wire line drill coring and dredging [MacLeod et al., 2001]. Multibeam bathymetry (Figure 2a) was collected throughout the cruise, and used in combination with the acoustic 


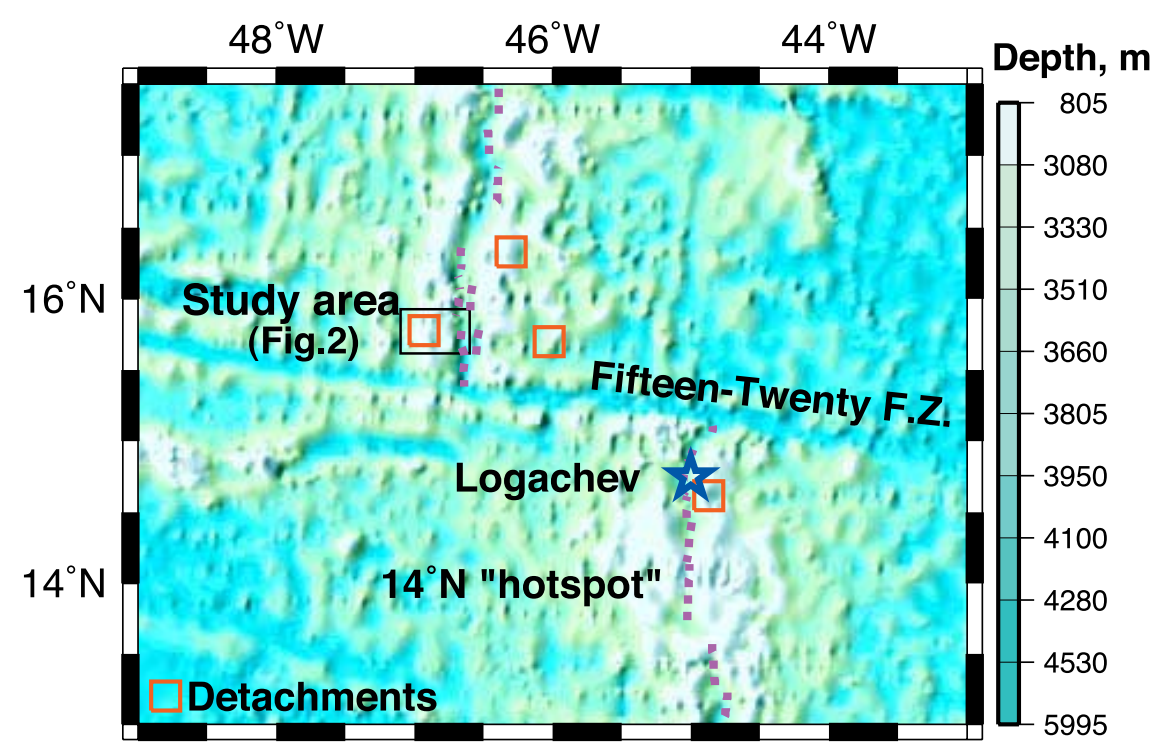

Figure 1. Location map of the study area. The Fifteen-Twenty area is characterized by the presence of several detachments (red squares), identified on the bathymetry data as continuous surfaces with corrugations parallel to the spreading direction. Peridotite outcrops are common along the ridge axis and in the proximity of the Fifteen-Twenty Fracture Zone, where the crust is thinnest. The shallow segment to the south coincides with the $14^{\circ} \mathrm{N}$ "hot spot" as identified geochemically [e.g., Dosso et al., 1991, 1993]. The location of the Logachev hydrothermal site is indicated. Bathymetry data from Smith and Sandwell [1997]. The dashed purple line corresponds to the ridge axis location.

backscatter data to select sampling targets. Dredged and cored rocks were described and curated onboard, and a subset of representative samples were cut and prepared for thin sectioning. Microstructural studies, electron microprobe analyses and Scanning Electron Microcopy (SEM) were conducted on selected thin sections, as described below.

\subsection{Bathymetry and Deep-Tow Acoustic Backscatter}

[6] Multibeam bathymetry was acquired with the SIMRAD EM12 system, and using a continuous Global Positioning (GPS). Data was cleaned manually to remove spurious points, and gridded at $100 \mathrm{~m}$ grid spacing (Figure 2a). Deeptow side-scan sonar (TOBI) was acquired and processed to obtain high-resolution backscatter maps of the area (see MacLeod et al. [2001, 2002] for details and Figure 1c therein) and to identify tectonic features (e.g., scarps and lineations, Figure 2b).

\subsection{Sampling}

[7] Rock samples were obtained using both dredges and the BGS BRIDGE wire line, oriented seabed rock drill [MacLeod et al., 1998; Allerton et al., 1999]. On-bottom dredge positions reported in Table 1 are estimated from the position of the ship, wire out, and local topography. Drill sites were selected using the seafloor images from the digital camera mounted on the BRIDGE drill frame. Positions of some of the drill sites and the dredges at the seafloor were determined using acoustic navigation. These differed by $<20 \mathrm{~m}$ from those of the ship's GPS position. Positions reported in Tables 1 and 2 correspond to the GPS position of the ship during drilling operations for consistency. Owing to the precise location of the BRIDGE drill, rock cores provide more accurate information on the spatial distribution of lithologies than that obtained from the less precisely located dredge samples.

\subsection{Optical and Scanning Electron Microscopy (SEM)}

[8] Thin sections of selected samples were prepared for both conventional optical and electronic microscopy. Both back-scattered electron (BSE) and element images were acquired with a JEOL JSM840A from Université Pierre et Marie Curie at 

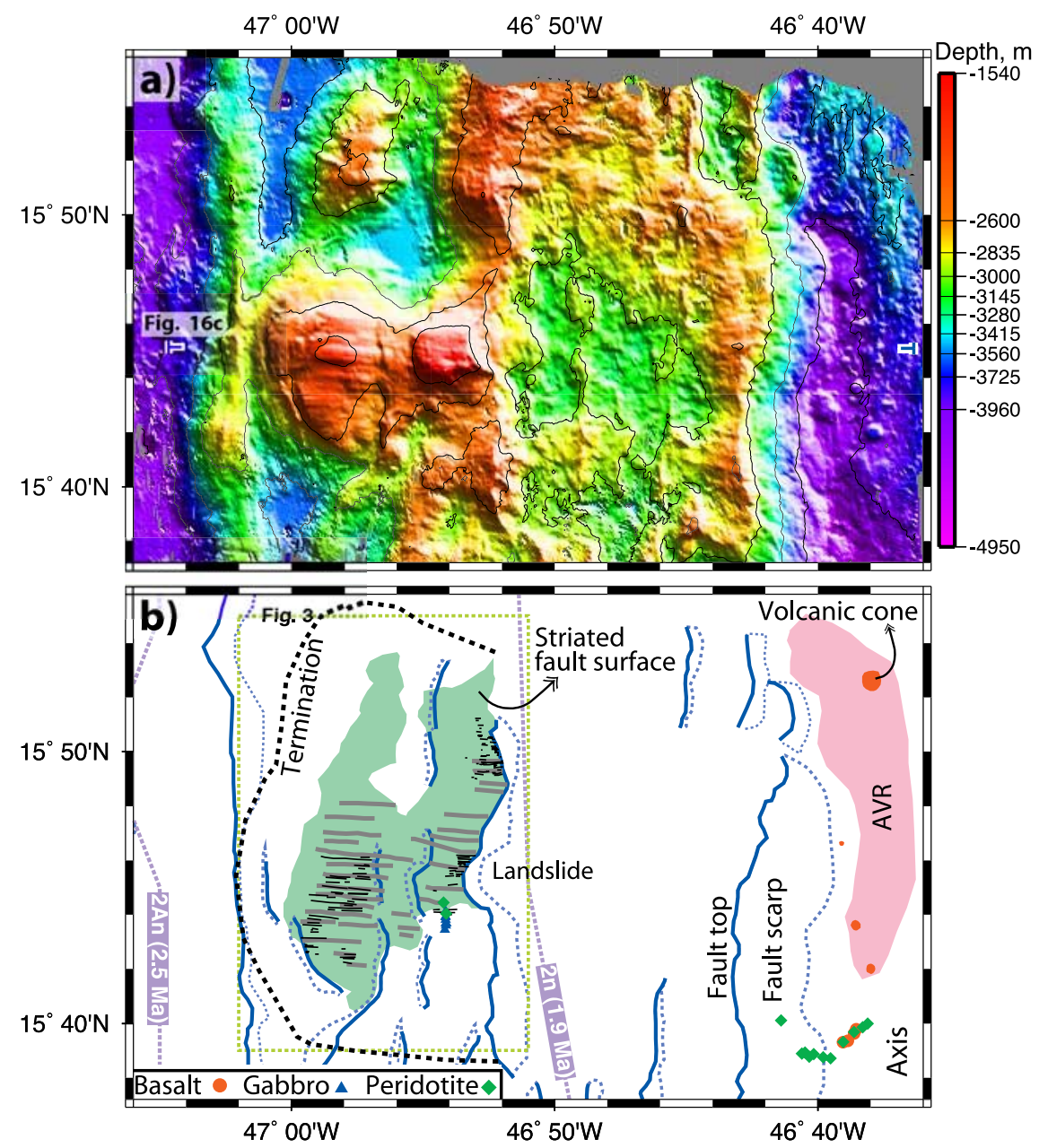

Figure 2. (a) Multibeam bathymetry and (b) geological interpretation of the study area. The detachment is located between anomalies $2 \mathrm{n}$ and 2An [Fujiwara et al., 2003], and cut by several fault scarps (blue lines). The detachment fault surface (light green) shows both bathymetric corrugations (thick grey lines) and acoustic backscatter striations (thin black lines) as identified in TOBI imagery (see backscatter images in MacLeod et al. [2002]). Gabbros and peridotites shown have been previously sampled at the south flank of the detachment and along the rift-bounding fault. The axial volcanic ridge (AVR, pink area) and the volcanic cones are also indicated (data from FARANAUT [Cannat et al., 1997] and MODE'98 cruises [Fujiwara et al., 2003]). The contour interval in a) is $500 \mathrm{~m}$, and the location of the bathymetric profile across the detachment in Figure 16c is also indicated.

a voltage of $25 \mathrm{kV}$, and a CamScan Series 4 from the University of Leeds at a voltage of $20 \mathrm{kV}$.

\subsection{Electron Microprobe Analyses}

[9] Mineral compositions were determined with a CAMECA SX50 microprobe at CAMPARIS, Université Pierre et Marie Curie. A combination of oxides and silicates were used as standards. The accelerating voltage was $15 \mathrm{kV}$, and the beam current $10 \nu \mathrm{A}$. Because minerals grain sizes in fault schists are very small (see description of microstructures), it was impossible to analyze single crystals of talc, amphibole or serpentine in the matrix. Spinel, amphibole and chlorite analyses are given in the Appendix (Tables A1-A3, respectively).

\subsection{X-Ray Diffraction (XRD) Analyses}

[10] Small amounts of powder $(\sim 1 \mathrm{~g})$ from selected samples was analyzed with a Phillips Automated Powder Diffractometer at Cardiff 
Table 1. Dredge Locations and Water Depth, Recovered Lithologies and Their Abundance

\begin{tabular}{|c|c|c|c|c|c|c|c|c|}
\hline \multirow[b]{2}{*}{$\begin{array}{l}\text { Dredge }^{\mathrm{a}} \\
\text { DR }\end{array}$} & \multicolumn{3}{|c|}{ Start $^{\mathrm{b}}$} & \multicolumn{3}{|c|}{ End $^{b}$} & \multirow[b]{2}{*}{ Lithologies } & \multirow[b]{2}{*}{ Abundance $^{c}$} \\
\hline & Lat. (N) & Lon. (W) & $\begin{array}{l}\text { Depth, } \\
\text { m }\end{array}$ & Lat. (N) & Lon. (W) & $\begin{array}{l}\text { Depth, } \\
\mathrm{m}\end{array}$ & & \\
\hline 01 & $13^{\circ} 47.050^{\prime}$ & $44^{\circ} 59.000^{\prime}$ & 3477 & $13^{\circ} 47.300^{\prime}$ & $44^{\circ} 59.320^{\prime}$ & 3373 & $\begin{array}{l}\text { Glassy basalt pillow, } \\
\text { MnO coating }\end{array}$ & B (4) \\
\hline 02 & $15^{\circ} 39.620^{\prime}$ & $46^{\circ} 04.280^{\prime}$ & 3506 & $15^{\circ} 39.910^{\prime}$ & $46^{\circ} 03.270^{\prime}$ & 3107 & $\begin{array}{l}\text { Serpentinized peridotite, } \\
\text { basalt pillows, } \\
\text { gabbro boulder }\end{array}$ & $\begin{array}{l}P(25), B \\
(14.5), G(5)\end{array}$ \\
\hline 03 & $15^{\circ} 44.510^{\prime}$ & $45^{\circ} 58.470^{\prime}$ & 2674 & $15^{\circ} 45.160^{\prime}$ & $45^{\circ} 57.800^{\prime}$ & 2381 & $\begin{array}{l}\text { Weathered basalt, } \\
\text { peridotite and } \\
\text { gabbro fragments }\end{array}$ & B (6), P (1), G \\
\hline 04 & $15^{\circ} 41.810^{\prime}$ & $45^{\circ} 03.470^{\prime}$ & 3409 & $15^{\circ} 41.840^{\prime}$ & $45^{\circ} 03.310^{\prime}$ & 3143 & $\begin{array}{l}\text { Serpentinized } \\
\text { peridotite pebbles }\end{array}$ & $\mathrm{P}$ \\
\hline 07 & $15^{\circ} 53.124^{\prime}$ & $46^{\circ} 51.822^{\prime}$ & 2282 & $15^{\circ} 53.720^{\prime}$ & $46^{\circ} 52.150^{\prime}$ & 2094 & $\begin{array}{l}\text { Serpentinized harzburgite, } \\
\text { Ol gabbro }\end{array}$ & $P(300), G$ \\
\hline 08 & $15^{\circ} 50.612^{\prime}$ & $46^{\circ} 56.988^{\prime}$ & 2885 & $15^{\circ} 51.213^{\prime}$ & $46^{\circ} 57.287^{\prime}$ & 2460 & $\begin{array}{l}\text { Serpentinized harzburgite, } \\
\text { gabbro pebbles }\end{array}$ & $P(16), G$ \\
\hline 09 & $15^{\circ} 52.801^{\prime}$ & $46^{\circ} 58.497^{\prime}$ & 2936 & $15^{\circ} 52.709^{\prime}$ & $46^{\circ} 57.961^{\prime}$ & 2597 & $\begin{array}{l}\text { Serpentinized harzburgite, } \\
\text { sedimentary breccia }\end{array}$ & P (48) \\
\hline 10 & $15^{\circ} 50.008^{\prime}$ & $46^{\circ} 53.963^{\prime}$ & 2765 & $15^{\circ} 50.199^{\prime}$ & $46^{\circ} 53.589^{\prime}$ & 2514 & $\begin{array}{l}\text { Fresh pillow basalt, } \\
\text { serpentinized peridotite }\end{array}$ & $\mathrm{B}(13), \mathrm{P}(7), \mathrm{F}$ \\
\hline 11 & $15^{\circ} 54.462^{\prime}$ & $46^{\circ} 48.248^{\prime}$ & 2680 & $15^{\circ} 54.933^{\prime}$ & $46^{\circ} 48.516^{\prime}$ & 2355 & $\begin{array}{l}\text { Pillow basalts with glass, } \\
\text { serpentinized peridotite } \\
\text { boulder }\end{array}$ & B (13), P (1) \\
\hline 12 & $15^{\circ} 43.503^{\prime}$ & $46^{\circ} 57.173^{\prime}$ & 2523 & $15^{\circ} 43.749^{\prime}$ & $46^{\circ} 57.358^{\prime}$ & 2308 & $\begin{array}{l}\text { Fragments of peridotite, } \\
\text { diabase, and basalt }\end{array}$ & $\mathrm{P}, \mathrm{B}, \mathrm{D}, \mathrm{F}, *$ \\
\hline 13 & $15^{\circ} 44.037^{\prime}$ & $46^{\circ} 56.786^{\prime}$ & 2426 & $15^{\circ} 44.815^{\prime}$ & $46^{\circ} 56.591^{\prime}$ & 2235 & $\begin{array}{l}\text { Serpentinized harzburgite } \\
\text { and dunite, pillow } \\
\text { fragments and diabase. } \\
\text { Serpentinite and } \\
\text { talc schists. }\end{array}$ & $\begin{array}{l}\mathrm{P}(42), \mathrm{B}(21), \\
\mathrm{D}(4), \mathrm{F}, *\end{array}$ \\
\hline 14 & $15^{\circ} 43.014^{\prime}$ & $46^{\circ} 56.666^{\prime}$ & 2622 & $15^{\circ} 43.418^{\prime}$ & $46^{\circ} 56.164^{\prime}$ & 2344 & $\begin{array}{l}\text { Weathered serpentinized } \\
\text { peridotite, } \\
\text { basalt pebbles }\end{array}$ & $\begin{array}{l}\mathrm{P}(4), \mathrm{B}(2.5), \\
\mathrm{F}, *\end{array}$ \\
\hline 15 & $15^{\circ} 43.010^{\prime}$ & $47^{\circ} 00.465^{\prime}$ & 2759 & $15^{\circ} 43.291^{\prime}$ & $46^{\circ} 59.912^{\prime}$ & 2471 & Serpentinized peridotite & $\mathrm{P}(102), \mathrm{F}$ \\
\hline 16 & $15^{\circ} 42.368^{\prime}$ & $46^{\circ} 54.971^{\prime}$ & 2857 & $15^{\circ} 42.541^{\prime}$ & $46^{\circ} 54.811^{\prime}$ & 2661 & Fine-grain gabbro & $\mathrm{G}(1.5)$ \\
\hline 17 & $15^{\circ} 43.443^{\prime}$ & $46^{\circ} 54.774^{\prime}$ & 2339 & $15^{\circ} 43.671^{\prime}$ & $46^{\circ} 54.770^{\prime}$ & 2119 & $\begin{array}{l}\text { Medium/coarse-grain } \\
\text { gabbro, dolerite }\end{array}$ & $\mathrm{G}(24), \mathrm{D}(8)$ \\
\hline 18 & $15^{\circ} 43.641^{\prime}$ & $46^{\circ} 54.489^{\prime}$ & 2216 & $15^{\circ} 43.886^{\prime}$ & $46^{\circ} 54.490^{\prime}$ & 1325 & $\begin{array}{l}\text { Medium/coarse-grain } \\
\text { gabbro, dolerite, } \\
\text { serpentinized peridotite }\end{array}$ & $\mathrm{G}, \mathrm{D}, \mathrm{P}$ \\
\hline 19 & $15^{\circ} 43.261^{\prime}$ & $46^{\circ} 53.593^{\prime}$ & 2414 & $15^{\circ} 43.234^{\prime}$ & $46^{\circ} 53.594^{\prime}$ & 2433 & $\begin{array}{l}\text { Clasts of serpentinized } \\
\text { peridotite }\end{array}$ & $\mathrm{P}$ \\
\hline 20 & $15^{\circ} 43.760^{\prime}$ & $46^{\circ} 53.348^{\prime}$ & 2215 & $15^{\circ} 44.106^{\prime}$ & $46^{\circ} 53.596^{\prime}$ & 1917 & $\begin{array}{l}\text { Medium- and coarse-grained } \\
\text { oxide gabbro }\end{array}$ & $\mathrm{G}(2)$ \\
\hline 21 & $15^{\circ} 44.603^{\prime}$ & $46^{\circ} 52.544^{\prime}$ & 2321 & $15^{\circ} 44.527^{\prime}$ & $46^{\circ} 52.722^{\prime}$ & 2246 & $\begin{array}{l}\text { Medium- and coarse-grained } \\
\text { gabbro }\end{array}$ & $\mathrm{G}(7)$ \\
\hline 22 & $15^{\circ} 46.032^{\prime}$ & $46^{\circ} 53.896^{\prime}$ & 2156 & $15^{\circ} 45.880^{\prime}$ & $46^{\circ} 53.891^{\prime}$ & 1972 & $\begin{array}{l}\text { Basalt fragments, } \\
\text { erpentinized peridotite, } \\
\text { gabbro pebbles }\end{array}$ & B (2), P (1.5), G \\
\hline 23 & $15^{\circ} 46.192^{\prime}$ & $46^{\circ} 52.535^{\prime}$ & 2601 & $15^{\circ} 46.293^{\prime}$ & $46^{\circ} 52.804^{\prime}$ & 2337 & $\begin{array}{l}\text { Cataclastic and mylonitic } \\
\text { foliated gabbro, } \\
\text { fine-grain dolerite }\end{array}$ & $\mathrm{G}(8), \mathrm{D}(4), F^{\mathrm{d}}$ \\
\hline 24 & $15^{\circ} 45.280^{\prime}$ & $46^{\circ} 52.891^{\prime}$ & 2296 & $15^{\circ} 45.287^{\prime}$ & $46^{\circ} 52.932^{\prime}$ & 2263 & Dolerite & $\mathrm{D}(0.5)$ \\
\hline 26 & $15^{\circ} 43.700^{\prime}$ & $46^{\circ} 52.176^{\prime}$ & 2770 & $15^{\circ} 43.831^{\prime}$ & $46^{\circ} 52.424^{\prime}$ & 2374 & $\begin{array}{l}\text { Serpentinized peridotite, } \\
\text { fine-grain dolerite, gabbro }\end{array}$ & $\begin{array}{l}P(4), D(2), \\
G(0.5), F\end{array}$ \\
\hline 27 & $15^{\circ} 43.596^{\prime}$ & $46^{\circ} 52.792^{\prime}$ & 2399 & $16^{\circ} 44.029^{\prime}$ & $46^{\circ} 52.834^{\prime}$ & 2289 & $\begin{array}{l}\text { Serpentinized peridotite } \\
\text { and gabbro pebbles }\end{array}$ & $\mathrm{P}, \mathrm{G}$ \\
\hline 28 & $15^{\circ} 44.110^{\prime}$ & $46^{\circ} 52.721^{\prime}$ & 2329 & $16^{\circ} 44.239^{\prime}$ & $46^{\circ} 52.820^{\prime}$ & 2077 & Gabbro and dolerite & G (14), D (2.5) \\
\hline 29 & $15^{\circ} 45.681^{\prime}$ & $46^{\circ} 52.901^{\prime}$ & 2354 & $15^{\circ} 45.651^{\prime}$ & $46^{\circ} 53.191^{\prime}$ & 2050 & Dolerite & $\mathrm{D}(2)$ \\
\hline
\end{tabular}


Table 1. (continued)

\begin{tabular}{|c|c|c|c|c|c|c|c|c|}
\hline \multirow[b]{2}{*}{$\begin{array}{l}\text { Dredge }^{\mathrm{a}} \\
\text { DR }\end{array}$} & \multicolumn{3}{|c|}{$\operatorname{Start}^{\mathrm{b}}$} & \multicolumn{3}{|c|}{ End $^{\mathrm{b}}$} & \multirow[b]{2}{*}{ Lithologies } & \multirow[b]{2}{*}{ Abundance $^{c}$} \\
\hline & Lat. (N) & Lon. (W) & $\begin{array}{l}\text { Depth, } \\
\text { m }\end{array}$ & Lat. (N) & Lon. (W) & $\begin{array}{l}\text { Depth, } \\
\text { m }\end{array}$ & & \\
\hline 30 & $15^{\circ} 43.013^{\prime}$ & $46^{\circ} 52.820^{\prime}$ & 2471 & $15^{\circ} 43.210^{\prime}$ & $46^{\circ} 52.949^{\prime}$ & 2300 & $\begin{array}{l}\text { Fine-grain dolerite, } \\
\text { altered gabbro }\end{array}$ & D (4), G (1) \\
\hline 31 & $15^{\circ} 42.231^{\prime}$ & $46^{\circ} 55.353^{\prime}$ & 2898 & $15^{\circ} 42.549^{\prime}$ & $46^{\circ} 55.705^{\prime}$ & 2532 & $\begin{array}{l}\text { Deformed gabbro, } \\
\text { vesicular basalt, } \\
\text { coarse-grain dolerite }\end{array}$ & $\begin{array}{l}\text { G (17), B (5.5) } \\
D(3)\end{array}$ \\
\hline 32 & $15^{\circ} 48.813^{\prime}$ & $46^{\circ} 45.340^{\prime}$ & 2745 & $15^{\circ} 49.512^{\prime}$ & $46^{\circ} 45.143^{\prime}$ & 2532 & $\begin{array}{l}\text { Pillow basalt fragments } \\
\text { with glass }\end{array}$ & B (11) \\
\hline
\end{tabular}

${ }^{a}$ Bold numbers indicate dredges that have been sampled and analyzed under optical microscope.

${ }^{\mathrm{b}}$ Start and end positions correspond to the estimated run of the dredge over the bottom.

${ }^{\mathrm{c}}$ Abundance is reported for the different lithologies, with the number of kilos recovered in parenthesis. B, Basalt; D, Diabase; G, Gabbro; P, Serpentinized peridotite; F, Fault rocks, mainly amphibole, talc and/or serpentinite schists; sediment content and dredges with sediment only have been omitted; asterisks: See Table 3 for XRD mineral identifications.

${ }^{\mathrm{d}}$ High-T gabbro mylonite.

University using standard analysis and identification techniques.

\subsection{Whole Rock Analyses}

[11] Whole rocks analyses have been performed at the SARM, CRPG-CNRS (Nancy, France). Major elements were analyzed with an ICP-AES JobinYvon JY70. REE were analyzed with an ICP-MS Perkin-Elmer ELAN 5000. Analytical results are given in the Appendix (Table A4).

\section{The $15^{\circ} 45^{\prime} \mathrm{N}$ Detachment: Setting, Structure, and Prior Results}

[12] The detachment at $15^{\circ} 45^{\prime} \mathrm{N}$ is located $35 \mathrm{~km}$ north of the Fifteen-Twenty Fracture Zone and $\sim 27 \mathrm{~km}$ west of the Mid-Atlantic Ridge axis, and is bounded by the anomalies $2 \mathrm{An}$ and $2 \mathrm{r}$ ( $\sim 2.5$ and $2.1 \mathrm{Ma}$, respectively), according to the interpretation of Fujiwara et al. [2003] (Figure 2b). The corrugated surface covers $>350 \mathrm{~km}^{2}$, extending $\sim 25 \mathrm{~km}$ along the axis and $\sim 15 \mathrm{~km}$ along-flowline, and, unlike most oceanic core complexes, is not directly associated with any clear transform or non-transform discontinuity of the ridge. The fault is inferred to have been active between $\sim 1$ M.y. [MacLeod et al., 2002] and 0.5 M.y., as indicated by the spreading rates and size of the fault surface, and by the interpreted magnetic anomalies, respectively. Magma supply to the present-day axis appears to be low within $50 \mathrm{~km}$ of the fracture zone, as indicated by extensive peridotite outcrops along the rift valley walls [Cannat and Casey, 1995; Escartín and Cannat, 1999] (Figure 2b), and by the thin $(<3 \mathrm{~km})$ seismic crust [Detrick et al., 1999]. Off axis gravity data also indicates an anomalously thin crust on both sides of the fracture zone, suggesting that reduced melt supply to the ridge axis has persisted over periods of $\sim 3 \mathrm{Ma}$ or more [Escartín and Cannat, 1999]. This area of thin crust is associated with irregular abyssal hill terrain where several detachments can be identified from the multibeam bathymetry data available [Escartín et al., 1999; Fujiwara et al., 2003] (Figure 1). Normal or anomalously high melt supply to the axis both to the north and south of this area can be inferred from bathymetry and gravity data [Escartín and Cannat, 1999; Fujiwara et al., 2003]. The southern gravity low coincides with a geochemical anomaly centered on the $14^{\circ} \mathrm{N}$ "hot spot" [Dosso et al., 1991, 1993] (Figure 1).

[13] The detachment surface shows a very clear bathymetric corrugations and acoustic backscatter lineations parallel to the spreading direction, which are associated with striated outcrops. The structural continuity of this surface, and the presence of striations and corrugation, allow us to define the extension of the exposed detachment fault surface, as shown in Figures 2 and 3. The bathymetry shows a long-wavelength undulation of $\sim 10 \mathrm{~km}$ in wavelength and $\sim 1 \mathrm{~km}$ in amplitude, with smaller-scale corrugations and slope breaks of 
Table 2. Location of BGS-Drill Sites and Recovered Lithologies

\begin{tabular}{|c|c|c|c|c|c|c|c|}
\hline $\mathrm{BR}$ & Lat. $(\mathrm{N})$ & Lon. (W) & $\begin{array}{l}\text { Depth, } \\
\text { m }\end{array}$ & $\begin{array}{c}\text { Core Length } \\
\text { Recovered }^{\mathrm{a}}, \mathrm{cm}\end{array}$ & Description $^{\mathrm{b}}$ & Lithologies $^{\mathrm{c}}$ & $\mathrm{XRD}^{\mathrm{d}}$ \\
\hline 21 & $15^{\circ} 44.640^{\prime}$ & $46^{\circ} 54.240^{\prime}$ & 1620 & & $\begin{array}{l}\text { Serpentinized harzburgite, } \\
\text { amph/talc schist }\end{array}$ & $\mathrm{P}, \mathrm{F}$ & \\
\hline 22 & $15^{\circ} 44.636^{\prime}$ & $46^{\circ} 54.247^{\prime}$ & 1614 & 20 & $\begin{array}{l}\text { Serpentinite/amphibolite from } \\
\text { striated outcrop, with sub-horizontal } \\
\text { shear zone on top. }\end{array}$ & $\mathrm{P}, \mathrm{F}$ & $*$ \\
\hline 23 & $15^{\circ} 44.626^{\prime}$ & $46^{\circ} 54.238^{\prime}$ & 1612 & 3.5 & Fault schist from striated outcrop & $\mathrm{P}, \mathrm{F}$ & $*$ \\
\hline 24 & $15^{\circ} 44.640^{\prime}$ & $46^{\circ} 54.241^{\prime}$ & 1626 & 7 & Gravel of sheared amphibole/serpentinite & $\mathrm{F}$ & $*$ \\
\hline 25 & $15^{\circ} 44.631^{\prime}$ & $46^{\circ} 54.238^{\prime}$ & 1611 & 33 & $\begin{array}{l}\text { Lithified breccia with serpentinite, } \\
\text { fault schists, and dolerite }\end{array}$ & $\mathrm{P}, \mathrm{D}, \mathrm{F}$ & $*$ \\
\hline 26 & $15^{\circ} 44.634^{\prime}$ & $46^{\circ} 54.243^{\prime}$ & 1616 & 3 & Fault schist, dolerite & F, D & \\
\hline 27 & $15^{\circ} 44.635^{\prime}$ & $46^{\circ} 54.248^{\prime}$ & 1608 & 9 & Fault schist, serpentinite, dolerite & $\mathrm{F}, \mathrm{P}, \mathrm{D}$ & $*$ \\
\hline 28 & $15^{\circ} 44.638^{\prime}$ & $46^{\circ} 54.234^{\prime}$ & 1616 & 14 & Amphibolite fault schist & $\mathrm{F}$ & $*$ \\
\hline 29 & $15^{\circ} 44.458^{\prime}$ & $46^{\circ} 53.618^{\prime}$ & 1586 & 30.5 & $\begin{array}{l}\text { Lithified breccia with gabbro, } \\
\text { serpentinite/amphibolite schists, } \\
\text { serpentinite, and dolerite }\end{array}$ & G, F, P, D & $*$ \\
\hline 30 & $15^{\circ} 44.463^{\prime}$ & $46^{\circ} 53.708^{\prime}$ & 1575 & 11 & Dolerite & D & \\
\hline 31 & $15^{\circ} 44.146^{\prime}$ & $46^{\circ} 54.133^{\prime}$ & 1610 & 46 & $\begin{array}{l}\text { Dolerite with possible chilled margin } \\
\text { and brecciated; serpentinite/amphibolite } \\
\text { shear zones }\end{array}$ & $\mathrm{D}, \mathrm{F}$ & \\
\hline 32 & $15^{\circ} 44.106^{\prime}$ & $46^{\circ} 54.135^{\prime}$ & 1644 & 3.5 & $\begin{array}{l}\text { Dolerite and serpentinite/amphibolite } \\
\text { schist pebbles }\end{array}$ & $\mathrm{F}, \mathrm{D}$ & \\
\hline 33 & $15^{\circ} 44.206^{\prime}$ & $46^{\circ} 54.135^{\prime}$ & 1581 & 67.5 & Dolerite, serpentinite/amphibolite schist & $\mathrm{D}, \mathrm{F}$ & $*$ \\
\hline 34 & $15^{\circ} 44.540^{\prime}$ & $46^{\circ} 53.113^{\prime}$ & 1756 & 13 & Dolerite and serpentinite/amphibolite schist & $\mathrm{D}, \mathrm{F}$ & $*$ \\
\hline 35 & $15^{\circ} 44.513^{\prime}$ & $46^{\circ} 53.030^{\prime}$ & 1813 & 9.5 & Dolerite & $\mathrm{D}$ & \\
\hline 36 & $15^{\circ} 45.380^{\prime}$ & $46^{\circ} 53.505^{\prime}$ & 1719 & 52 & Dolerite & $\mathrm{D}$ & $*$ \\
\hline 37 & $15^{\circ} 45.102^{\prime}$ & $46^{\circ} 54.972^{\prime}$ & 1755 & 60.5 & $\begin{array}{l}\text { Lithified breccia with vesicular basalt } \\
\text { clasts and serpentinite/amphibilite schist, } \\
\text { serpentinized peridotite }\end{array}$ & $\mathrm{B}, \mathrm{P}, \mathrm{F}$ & $*$ \\
\hline 39 & $15^{\circ} 44.153^{\prime}$ & $46^{\circ} 54.628^{\prime}$ & 1661 & 44 & $\begin{array}{l}\text { Lithified breccia with dolerite, } \\
\text { some clasts of serpentinite/amphibolite } \\
\text { schist and basalt }\end{array}$ & $\mathrm{D}, \mathrm{F}, \mathrm{B}$ & $*$ \\
\hline 40 & $15^{\circ} 44.326^{\prime}$ & $46^{\circ} 54.522^{\prime}$ & 1557 & 53 & Dolerite and amphibole/talc schist & F, D & $*$ \\
\hline 41 & $15^{\circ} 44.477^{\prime}$ & $46^{\circ} 54.440^{\prime}$ & 1560 & 5 & $\begin{array}{l}\text { Serpentinite/amphibolite schist, } \\
\text { and dolerite pebbles }\end{array}$ & $\mathrm{F}, \mathrm{D}$ & $*$ \\
\hline 43 & $15^{\circ} 44.934^{\prime}$ & $46^{\circ} 53.341^{\prime}$ & 1670 & 30 & $\begin{array}{l}\text { Lithified breccia with serpentinized } \\
\text { peridotite and dolerite, and core of } \\
\text { dolerite and serpentinite/amphibole schist }\end{array}$ & $\mathrm{P}, \mathrm{D}, \mathrm{F}$ & $*$ \\
\hline 45 & $15^{\circ} 44.330^{\prime}$ & $46^{\circ} 54.224^{\prime}$ & 1544 & 65 & $\begin{array}{l}\text { Dolerite cross-cut by talc-bearing } \\
\text { shear zones; serpentinized peridotites }\end{array}$ & $\mathrm{D}, \mathrm{P}, \mathrm{F}$ & $*$ \\
\hline 46 & $15^{\circ} 44.053^{\prime}$ & $46^{\circ} 54.284^{\prime}$ & 1620 & 11.5 & Dolerite, fault schist gravel & $\mathrm{D}, \mathrm{F}$ & $*$ \\
\hline 47 & $15^{\circ} 44.315^{\prime}$ & $46^{\circ} 53.919^{\prime}$ & 1606 & 43 & Serpentinized peridotite pebbles & $\mathrm{P}$ & * \\
\hline 49 & $15^{\circ} 44.578^{\prime}$ & $46^{\circ} 55.145^{\prime}$ & 1750 & 53.5 & Dolerite & $\mathrm{D}$ & \\
\hline 50 & $15^{\circ} 45.867^{\prime}$ & $46^{\circ} 54.816^{\prime}$ & 2044 & 49.5 & serpentinized harzburgite and dunite & $\mathrm{P}$ & * \\
\hline 52 & $15^{\circ} 43.719^{\prime}$ & $46^{\circ} 53.868^{\prime}$ & 2064 & 14 & Dolerite & $\mathrm{D}$ & \\
\hline 53 & $15^{\circ} 44.176^{\prime}$ & $46^{\circ} 53.010^{\prime}$ & 1681 & 19 & Dolerite & $\mathrm{D}$ & \\
\hline 54 & $15^{\circ} 44.227^{\prime}$ & $46^{\circ} 54.026^{\prime}$ & 1614 & 2 & Dolerite and fault schist & $\mathrm{D}, \mathrm{F}$ & $*$ \\
\hline 55 & $15^{\circ} 44.227^{\prime}$ & $46^{\circ} 54.016^{\prime}$ & 1617 & 22.5 & Altered serpentinized harzburgite and dunite & $\mathrm{P}$ & * \\
\hline 56 & $15^{\circ} 44.265^{\prime}$ & $46^{\circ} 52.477^{\prime}$ & 2272 & 14 & Dolerite & $\mathrm{D}$ & \\
\hline 57 & $15^{\circ} 45.908^{\prime}$ & $46^{\circ} 53.265^{\prime}$ & 2013 & 54 & $\begin{array}{l}\text { Dolerite, serpentinized peridotite, } \\
\text { fault schist pebbles }\end{array}$ & $\mathrm{D}, \mathrm{P}, \mathrm{F}$ & \\
\hline 58 & $15^{\circ} 44.715^{\prime}$ & $46^{\circ} 58.261^{\prime}$ & 1887 & 2 & Dolerite pebbles & $\mathrm{D}$ & \\
\hline 60 & $15^{\circ} 44.597^{\prime}$ & $46^{\circ} 58.252^{\prime}$ & 1942 & 25 & $\begin{array}{l}\text { Highly weathered serpentinized } \\
\text { harzburgite }\end{array}$ & $\mathrm{P}$ & $*$ \\
\hline 61 & $15^{\circ} 45.490^{\prime}$ & $46^{\circ} 59.304^{\prime}$ & 2091 & 20 & Serpentinized harzburgite & $\mathrm{P}$ & $*$ \\
\hline 62 & $15^{\circ} 46.499^{\prime}$ & $46^{\circ} 58.251^{\prime}$ & 2305 & 48 & Serpentinized harzburgite, dolerite & $\mathrm{P}, \mathrm{D}$ & \\
\hline 63 & $15^{\circ} 50.676^{\prime}$ & $46^{\circ} 52.337^{\prime}$ & 2015 & 26 & Dolerite, serpentinite and fault schist pebbles & $\mathrm{D}, \mathrm{P}$ & $*$ \\
\hline 64 & $15^{\circ} 49.970^{\prime}$ & $46^{\circ} 52.041^{\prime}$ & 2242 & 2 & Fault schist pebbles & $\mathrm{F}$ & $*$ \\
\hline 65 & $15^{\circ} 51.111^{\prime}$ & $46^{\circ} 52.115^{\prime}$ & 2133 & 10 & Dolerite and fault schist pebbles & $\mathrm{D}, \mathrm{F}$ & $*$ \\
\hline 66 & $15^{\circ} 51.089^{\prime}$ & $46^{\circ} 51.592^{\prime}$ & 2324 & - & No core - serpentinite (?) fragments & $\mathrm{P}$ & \\
\hline
\end{tabular}


Table 2. (continued)

\begin{tabular}{|c|c|c|c|c|c|c|c|}
\hline $\mathrm{BR}$ & Lat. $(\mathrm{N})$ & Lon. (W) & $\begin{array}{l}\text { Depth, } \\
\text { m }\end{array}$ & $\begin{array}{l}\text { Core Length } \\
\text { Recovered }^{\mathrm{a}}, \mathrm{cm}\end{array}$ & Description $^{\mathrm{b}}$ & Lithologies $^{c}$ & $\mathrm{XRD}^{\mathrm{d}}$ \\
\hline 67 & $15^{\circ} 52.709^{\prime}$ & $46^{\circ} 52.191^{\prime}$ & 2204 & 11 & Dolerite and fault schist pebbles & $\mathrm{D}, \mathrm{F}$ & $*$ \\
\hline 70 & $15^{\circ} 45.386^{\prime}$ & $46^{\circ} 53.505^{\prime}$ & 1718 & 22 & Fault schist pebbles & $\mathrm{F}$ & $*$ \\
\hline 71 & $15^{\circ} 44.144^{\prime}$ & $46^{\circ} 54.242^{\prime}$ & 1586 & 52 & $\begin{array}{l}\text { Dolerite in contact with fault } \\
\text { schist and cataclasite }\end{array}$ & $\mathrm{D}, \mathrm{F}$ & $*$ \\
\hline 72 & $15^{\circ} 44.154^{\prime}$ & $46^{\circ} 54.422^{\prime}$ & 1589 & 27 & $\begin{array}{l}\text { Lithified breccia with serpentinized } \\
\text { harzburgite, gabbro and dolerite }\end{array}$ & $\mathrm{P}, \mathrm{G}, \mathrm{D}$ & \\
\hline 73 & $15^{\circ} 43.562^{\prime}$ & $46^{\circ} 54.366^{\prime}$ & 2295 & 36.5 & Gabbro cross-cut by dolerite & G, D & \\
\hline 74 & $15^{\circ} 43.846^{\prime}$ & $46^{\circ} 54.629^{\prime}$ & 1934 & 35 & Coarse-grain gabbro with cataclastic seams & $\mathrm{G}$ & \\
\hline 75 & $15^{\circ} 43.682^{\prime}$ & $46^{\circ} 55.041^{\prime}$ & 2186 & 34 & Dolerite with screens of fault schist & $\mathrm{D}, \mathrm{F}$ & \\
\hline 76 & $15^{\circ} 44.050^{\prime}$ & $46^{\circ} 55.294^{\prime}$ & 2066 & 33 & Dolerite with screens of fault schist & $\mathrm{D}, \mathrm{F}$ & $*$ \\
\hline 77 & $15^{\circ} 43.945^{\prime}$ & $46^{\circ} 53.715^{\prime}$ & 1992 & 16 & Medium to fine-grain gabbro & $\mathrm{G}$ & \\
\hline 78 & $15^{\circ} 44.087^{\prime}$ & $46^{\circ} 53.291^{\prime}$ & 2080 & 26 & Serpentinized dunite with melt impregnations & $\mathrm{P}$ & $*$ \\
\hline 79 & $15^{\circ} 44.048^{\prime}$ & $46^{\circ} 54.172^{\prime}$ & 1656 & 42 & Dolerite, dolerite and fault schist pebbles on top & $\mathrm{D}, \mathrm{F}$ & * \\
\hline 80 & $15^{\circ} 44.061^{\prime}$ & $46^{\circ} 53.992^{\prime}$ & 1792 & 8.5 & Dolerite pebbles, minor amounts of gabbro & $\mathrm{D}, \mathrm{G}$ & \\
\hline 81 & $15^{\circ} 44.066^{\prime}$ & $46^{\circ} 53.602^{\prime}$ & 1965 & 31 & Dolerite & $\mathrm{D}$ & \\
\hline 82 & $15^{\circ} 43.953^{\prime}$ & $46^{\circ} 53.990^{\prime}$ & 1854 & 41.5 & Gabbro and brecciated dolerite & $\mathrm{G}, \mathrm{D}$ & \\
\hline 84 & $15^{\circ} 43.654^{\prime}$ & $46^{\circ} 53.993^{\prime}$ & 2112 & - & No core; gabbro fragments on BGS Drill frame & $\mathrm{G}$ & \\
\hline 85 & $15^{\circ} 44.076^{\prime}$ & $46^{\circ} 54.429^{\prime}$ & 1674 & 58 & Gabbro & $\mathrm{G}$ & \\
\hline 86 & $15^{\circ} 44.634^{\prime}$ & $46^{\circ} 54.245^{\prime}$ & 1625 & 27.5 & Fault schist, serpentinized peridotite, dolerite & $\mathrm{P}, \mathrm{D}, \mathrm{F}$ & $*$ \\
\hline 87 & $15^{\circ} 44.480^{\prime}$ & $46^{\circ} 54.425^{\prime}$ & 1563 & 8.5 & Dolerite, serpentinized peridotite pebbles & $\mathrm{D}, \mathrm{P}$ & \\
\hline 89 & $15^{\circ} 44.036^{\prime}$ & $46^{\circ} 53.521^{\prime}$ & 2018 & 5.5 & Dolerite & $\mathrm{D}$ & \\
\hline 90 & $15^{\circ} 44.018^{\prime}$ & $46^{\circ} 54.068^{\prime}$ & 1745 & 39 & Dolerite, fault schist & $\mathrm{D}, \mathrm{F}$ & $*$ \\
\hline 91 & $15^{\circ} 44.159^{\prime}$ & $46^{\circ} 54.334^{\prime}$ & 1575 & 20 & Dolerite, fault schist & D, F & $*$ \\
\hline 92 & $15^{\circ} 43.542^{\prime}$ & $46^{\circ} 38.658^{\prime}$ & 3968 & 3968 & Pillow basalt & $\mathrm{B}$ & \\
\hline
\end{tabular}

${ }^{\mathrm{a}}$ Estimated actual length of sample cored, including sediments.

${ }^{\mathrm{b}}$ Description of lithologies present in the core.

${ }^{\mathrm{c}}$ Summary of lithologies present in the cores, ordered from most to least abundant; the presence of fault rocks is also indicated. B, Basalt; D, Dolerite; G, Gabbro; P, Peridotite; F, Fault rock.

${ }^{\mathrm{d}}$ See XRD analyses in Table 3.

wavelengths of $\sim 1 \mathrm{~km}$ and amplitudes of $<200 \mathrm{~m}$. Finer striations in the acoustic backscatter images (see Figure 1c in MacLeod et al. [2002]) have wavelengths of $100 \mathrm{~m}-1 \mathrm{~km}$, and are similar to those observed at detachments north of the Atlantis FZ [Cann et al., 1997] and along the South West Indian Ridge [Searle et al., 1999]. Striations at $\mathrm{cm}$-scale, and also parallel to the spreading direction, are observed at basement outcrops at the summit of the detachment [MacLeod et al., 2002, Figure 2]. A high-angle, ridge-parallel normal fault with a vertical displacement of $>1 \mathrm{~km}$ (Figure 2a) terminates the detachment toward the ridge, while smaller faults define a ridge-parallel graben at the centre of the detachment. The interference of this axisparallel graben with the large-scale, axis-perpendicular undulations define four shallow areas or knolls. The striated surface appears to be a continuous structure with a rapid transition into abyssal hill terrain toward the west, north and south, with no clear tectonic boundary to accommodate the change in tectonic structure (Figure 2). The slopes around the detachment and the ridge-facing fault are steep and show numerous mass-wasting scarps that dissect the striated surface and expose deeper structural levels of the footwall.

[14] Dredges and drill sites selected during cruise JR63 concentrated both on the detachment surface and on the fault-bounded and mass-wasted scarps beneath it. These scarps were targeted to sample rocks associated with or in structural proximity to the detachment fault, and lithologies of the footwall proper. Geological observations and rock samples available from a Shinkai dive (MODE'98 cruise Dive 422 [M. Braun, personal communication; Matsumoto et al., 1998]) along the southeast flank of the southeast knoll (Figure 2b) yielded gabbroic samples in the lower part of the slope. Gabbros, harzburgites and dunites were found near the summit of the knoll, where sub-horizontal striated fault surfaces were recognized during Dive 

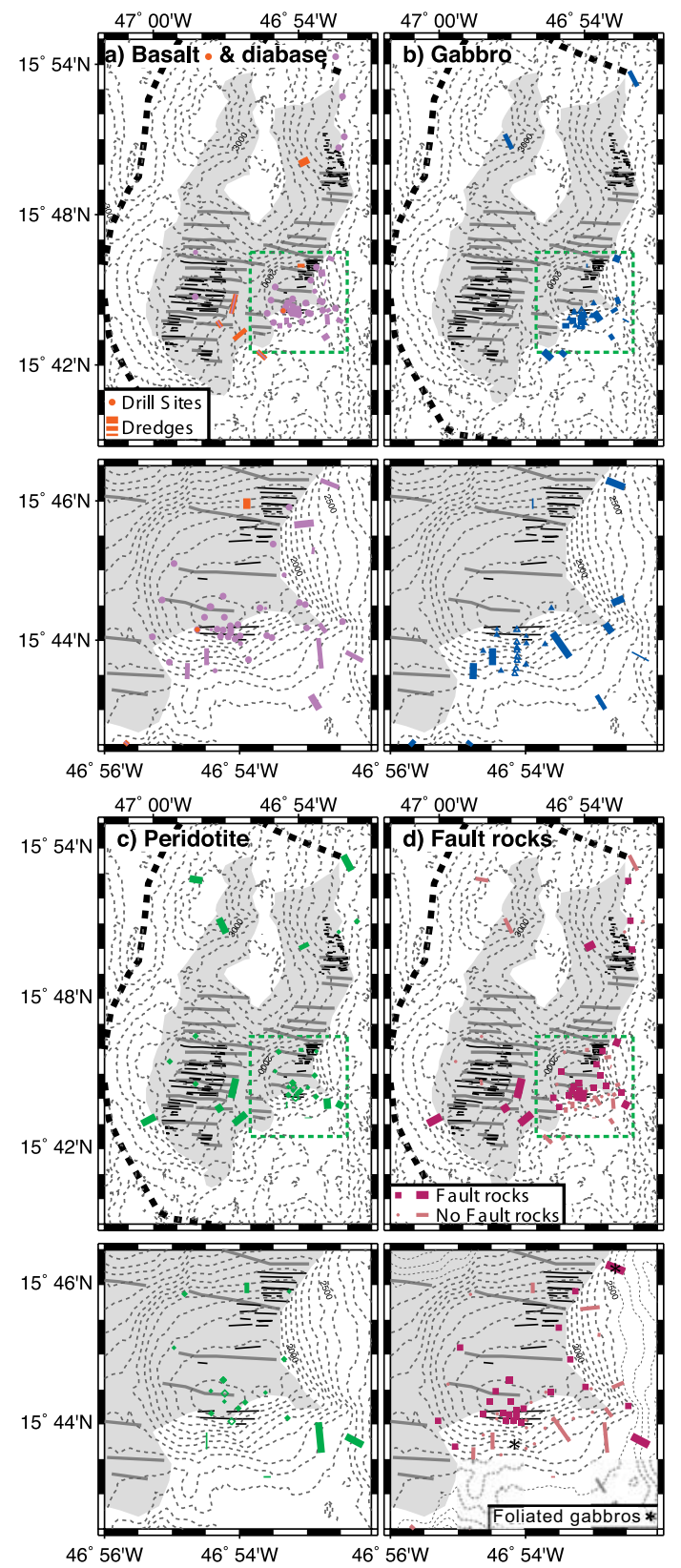

Figure 3. Distribution of (a) basalt and diabase, (b) gabbro, (c) peridotite and (d) fault rocks in the study area. The bottom panels are enlargements of the dashed rectangle on the top maps. Solid symbols are samples from JR63 (this study, Tables 1 and 2), and open symbols correspond to previous cruises (see Figure 2). The fault surface (light grey surface), the striations and lineations of the fault surface (black and dark grey lines), and the termination of the detachment (black dashed line) are also indicated as in Figure 2. Thickness of the dredge lines in Figures $3 a-3 c$ indicate relative abundance of lithologies within a dredge. The two sites where foliated gabbros have been found are also indicated in Figure 3d (see text).
422 [Matsumoto et al., 1998]. A near-bottom digital camera survey ( $R V$ Atlantis Cruise A4-4 [MacLeod et al., 2002, Figure 3]) also revealed several basement outcrops with striations sub-parallel to the spreading direction at the summit of the southeast knoll.

\section{Lithologies}

[15] Dredges and drilled cores recovered highly sheared fault rocks, in addition to peridotites, gabbros, diabases and minor basalt. The geographical occurrence of these rocks, as well as their textures and microstructures, provide constraints on the composition of the lithosphere, on the relationship between deformation and emplacement of lithologies, and on the conditions of deformation along the detachment fault.

[16] Because of the observed variability in lithologies at small spatial scales $(<5 \mathrm{~km})$, sampling was concentrated on the southeast knoll of the detachment, with sparser sampling throughout the fault surface and surrounding areas (Figure 3). Diabase and minor basalt are found primarily along the detachment surface or immediately below it (Figure 3a), while gabbro is exposed preferentially along mass-wasting scarps on the flanks of the detachment, with very rare occurrences on the detachment fault surface itself (Figure 3b). Peridotites are ubiquitous and overlay the gabbros (Figures $3 b-3 c$ ), demonstrating that the lithosphere is compositionally heterogeneous [e.g., Cannat, 1993]. Fault rocks sampled in situ are restricted to the detachment surface, and were also recovered in a few dredge hauls at its flanks (Figure 3d).

[17] The sedimentary cover is discontinuous and inferred to be thin where present. Fine carbonate sediments blanket areas between elevated, elongated outcrops parallel to spreading. Basement striations are clearly visible in the acoustic backscatter images [MacLeod et al., 2002, Figure 1], and basement rocks were successfully drilled in areas that appear sedimented in the BRIDGE-drill images, implying that no more than a few tens of $\mathrm{cm}$ in sediment thickness. Carbonate-cemented breccias are very localized in the immediate vicinity of small scarps ( $<10 \mathrm{~m}$ in vertical relief) along 
basement outcrops at the surface of the detachment, or along the flanks. Sediment-filled fractures are also present in cores, particularly in fault rocks. Coarser rubble derived from the basement is present over large areas of the detachment surface, and its thickness is unconstrained. The camera survey clearly shows that rubble is shed from the small scarps surrounding the elevated basement outcrops. Our sampling and seafloor images also showed large areas of the detachment fault summit covered with talc and amphibolite schist gravel derived from disaggregated fault rocks.

\subsection{Basalt and Diabase}

[18] We differentiate between rocks emplaced at the seafloor-water interface (basalt) and those emplaced below the seafloor (diabase), as indicated by the macroscopic texture of the samples (shape and presence or absence of glassy rims and vesicles, and intrusive contacts when present). Digital images from the drill frame also provide information on fracture patterns of outcrops and/or on the morphology of rock blocks, and allow the identification of extrusive basalt (e.g., pillow-like structures) when present.

[19] Basalts are scarce along the detachment surface, and are found in very few drill cores only as a minor proportion of the clasts in sedimentary breccias (Tables 1 and 2). None of the seafloor digital images show the lobate surfaces of pillow basalts, nor scarps with radial fractures characteristic of pillow sections found along other oceanic detachments [e.g., Cann et al., 1997; Tucholke et al., 2001]. Acoustic backscatter images revealed no volcanic features (e.g., hummocky terrain). By contrast, at several sites surrounding the detachment (Table 2) we recovered basalts from seafloor characterized by the typical abyssal hill morphology of crust formed at slow-spreading axes.

[20] Diabases are very common along the fault surface or at the shallowest levels of the escarpment surrounding the detachment (Figure 3a). These rocks were drilled either at striated rock outcrops or in areas with massive, polygonal rock blocks, where no pillow lavas or fragments were apparent. We have identified planar chilled margins within diabase cores (e.g., BR31, Figure 4), as well as chilled intrusive contacts between diabase and the fault rock (e.g., talc schist in BR71, Figures 4 and $5 \mathrm{a}$ ), which are direct evidence of an intrusive mode of emplacement of these samples, most probably as dykes, although fault-parallel sills may also be present. These magmatic contacts are very sharp and tortuous, even at the microscopic scale. In Figure 5a, a diabase in contact with fault rock shows no penetrative deformation, and no evidence of a substantial alteration gradient associated with the shear zone.

[21] Tectonic contacts between diabase and dolerite are more complex, as the alternation of diabase and fault rocks at scales of $<10 \mathrm{~cm}$ demonstrate (e.g., BR40, Figure 4). Optical microscope observations show that diabase fragments within fault rocks are composed of large clasts $(>1 \mathrm{~cm})$ with varying textures juxtaposed by narrow brittle faults. All diabase clasts are variably chloritized and none show penetrative deformation. In the immediate vicinity of the tectonic contacts small clasts of chloritized diabase $(<0.2 \mathrm{~mm})$ are incorporated in the fault zone (Figure 5b). SEM images (Figure 5c) show small amounts of brittle deformation within the diabase in immediate contact with fault rocks, but limited to a very narrow zone $(<0.5 \mathrm{~mm})$, with reworking of small clasts. None of the diabases examined showed evidence of plastic deformation microstructures.

\subsection{Gabbro}

[22] Gabbros crop out preferentially along the scarps that flank the detachment, with very rare occurrences over the detachment fault itself, mostly limited to small fragments in breccias, or embedded in the fault rocks (e.g., sample BR40; see Table 2). Most of the gabbros have been recovered from the southern flank of the southeast knoll, immediately below the surface of the detachment, drilled from outcrops of massive rock or large blocks with polygonal joints.

[23] Gabbros are massive and relatively little altered, with variations both in composition and grain size at the scale of individual cores (e.g., BR85, Figure 4). Preliminary microstructural 
BR31

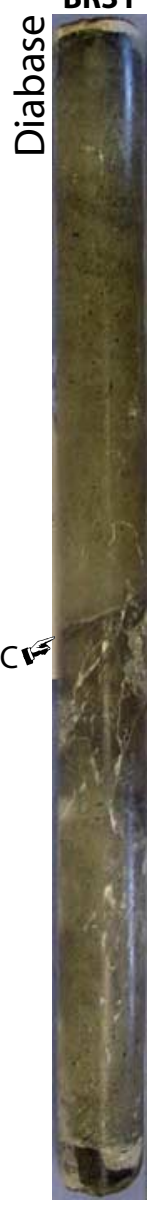

BR85

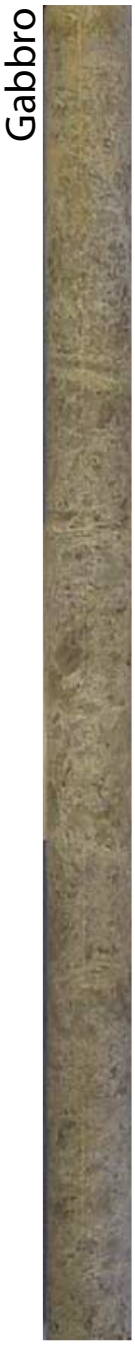

$5 \mathrm{~cm}$

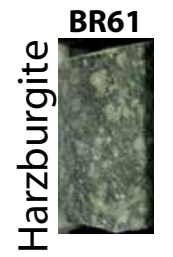

BR50

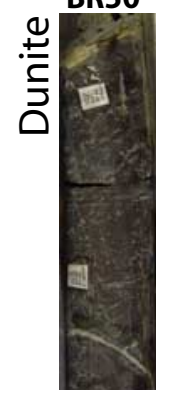

BR22
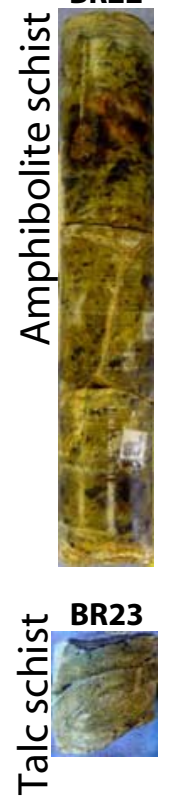

BR40
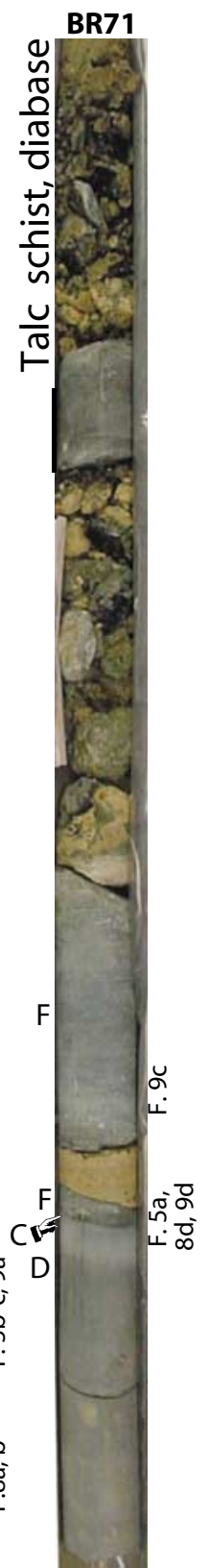

Figure 4. Images of selected rock cores. BR31: Undeformed diabase with chilled margin (C) recovered along the detachment surface. BR85: Continuous gabbro core with no evidence of widespread, high-temperature deformation. BR61: Undeformed, serpentinized harzburgite with late-stage veining. BR50: Altered, undeformed dunite. BR22: Amphibolite schist drilled in the immediate vicinity of a striated basement outcrop [MacLeod et al., 2002, Figure 2]. BR23: Talc schist sampled from the striated basement (BR22), with sub-horizontal foliation. BR40: Core recovered at the detachment surface showing an alternance of amphibolite and talc schists (F) with clasts of diabase brittlely deformed (D). BR71: Core with talc mylonites (F) and cataclasites and chill margin (C) at the contact with diabase (D). The position of micrographs in Figures 5, 8, and 9 are also indicated.

observations show magmatic textures, usually with no or very minor plastic deformation (i.e., slight bending of plagioclase crystals, or very localized, mm-scale shear zones). Higher strain deformation in the form of $\mathrm{cm}$-scale protomylonitic to mylonitic shear zones in a few gabbro blocks was observed in samples from dredge DR23 at a mass-wasted scarp of the southeast knoll (Fault rocks section 

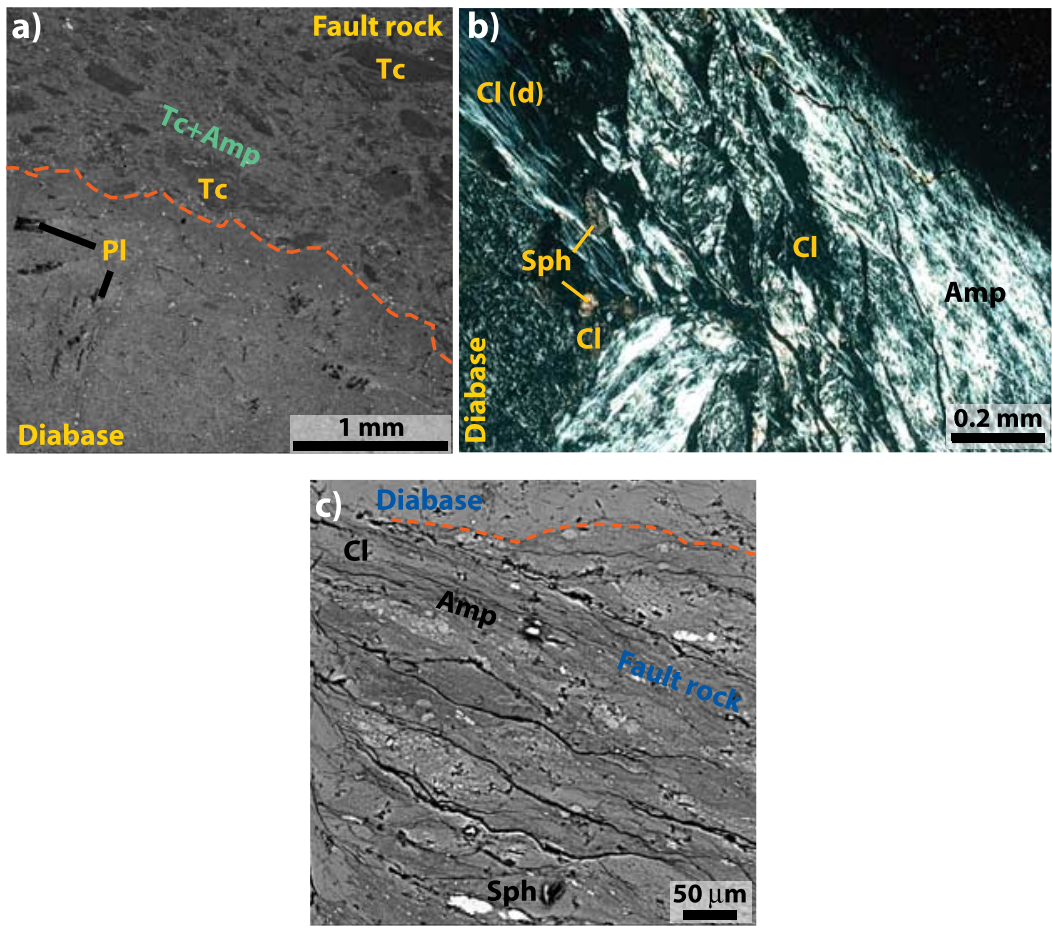

Figure 5. (a) SEM image of the sharp and irregular intrusive contact of diabase and the fault rock (red dashed line; BR71C, see Figure 4). No penetrative deformation nor alteration is observed near the diabase. The fault schist is composed mainly of talc (Tc) clasts embedded in a talc +amphibole (Amp) matrix. Pl: Plagioclase. (b) Optical and (c) SEM, tectonic contact of diabase with fault rocks (BR40A, see Figure 4). Clasts of fully chloritized diabase are incorporated in the shear zone (Figure 5b), composed mainly of amphibolite and chlorite (Cl). Sph: accessory sphene. Diabase in the immediate vicinity of the contact (Figure 5c) shows limited brittle cracking over a narrow band, with no penetrative deformation. Small diabase clasts $(<25 \mu \mathrm{m})$ are reworked into the fault rock.

below, Table 1, and Figures $2 \mathrm{~b}$ and $3 \mathrm{~b}$ ). These shear bands appear to be minor as they are very localized and are not penetrative even at the scale of hand specimens.

\subsection{Peridotites}

[24] Harzburgites and dunites are recovered both from the detachment fault surface itself, and along the flanking scarps beneath it (Figure 3c). Most of these peridotites have been statically serpentinized, and show the typical serpentine mesh texture replacing olivine crystals, and serpentine pyroxene pseudomorphs (bastites [see MacLeod et al., 2002, Figure 3]). Magnetite and other oxides are very abundant in some samples, and tend to concentrate along mesh rims and within serpentine veins. Unaltered spinels and relict fresh fragments of olivine crystals (Figure 6a) are found in some of the samples. In addition to static serpentinization, some samples display direct alteration of fresh olivine to talc (e.g., DR13-3, Figure 6a), or talc shear zones grading into halos of undeformed talc replacing the pre-existing serpentine (DR26-5, Figure 6b).

[25] There is no clear record of plastic deformation either prior to or after serpentinization. Brittle deformation is present, in the form of distributed fracturing, shear zones localized at the scale of a thin section, or veins of serpentine, talc, amphibolite or calcite. Brittle damage with no obvious associated strain is recognized from broken bastites whose fragments show no noticable relative translation or rotation, that are surrounded by serpentine or talc veins (e.g., Figure $6 \mathrm{a}$ ) or halos. This brittle deformation therefore accommodates minor amounts of strain; most samples, however, show no deformation. Localized shear zones are cataclastic and composed of serpentine and chlorite clasts, in addition to the talc shear zones described above (Figure 6b). Veins are common in most samples, 
Geochemistry
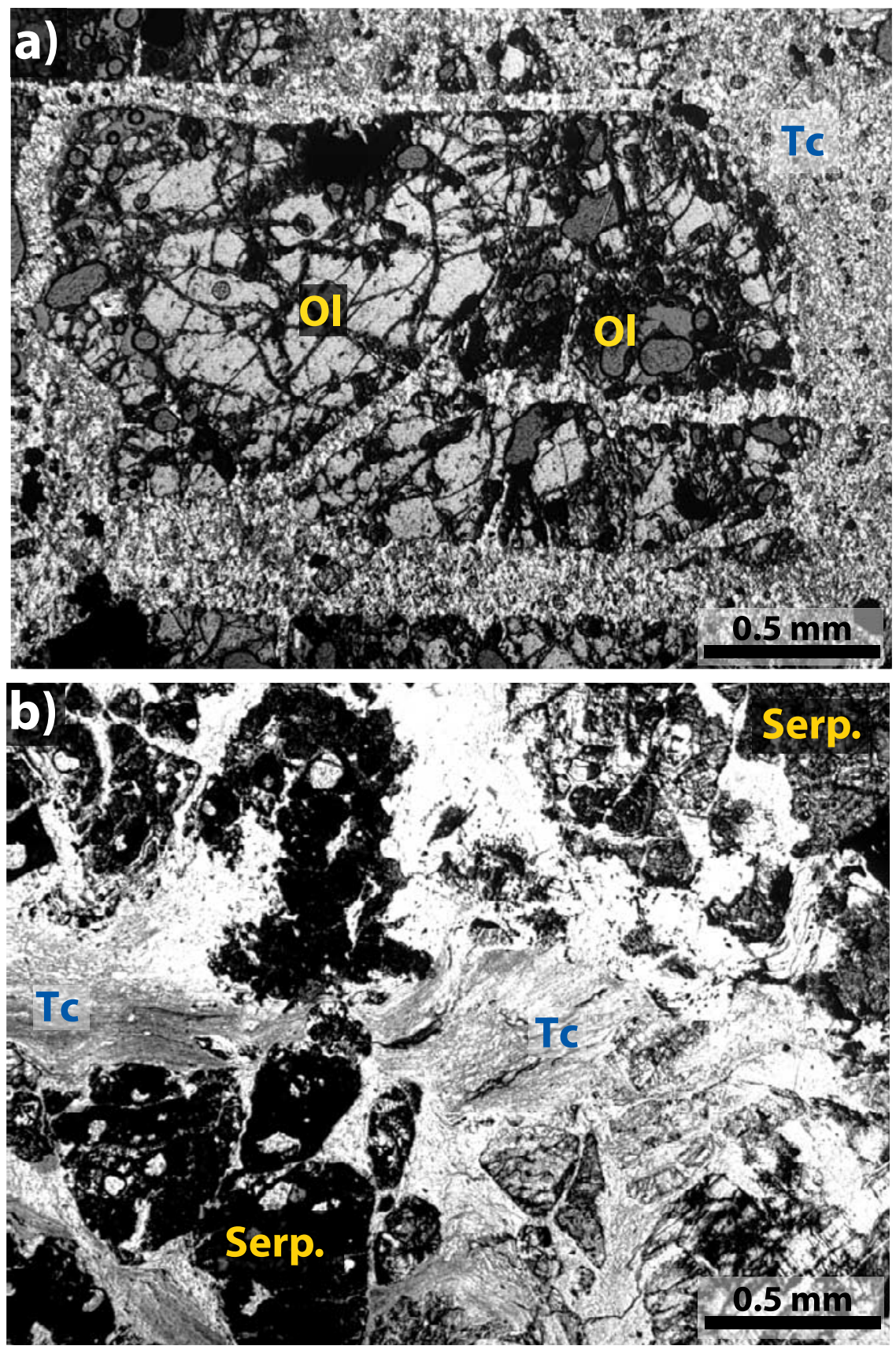

Figure 6. (a) Static talc (Tc) alteration after olivine (Ol) along pre-existing fractures (sample DR13-3). (b) Talc shear zones cross-cutting a serpentinized peridotite (serp.). The peridotite was serpentinized prior to talc alteration, as indicated by the gradual textural transition from the highly-deformed shear zones to undeformed talc halos which replace the undeformed, mesh-textured serpentinized peridotite (sample DR26-5).

recording late-stage, static crack dilation [e.g., O'Hanley, 1992].

\subsection{Fault Rocks}

[26] In this paper we differentiate between highly sheared rocks recovered mainly along the exposed detachment fault (fault schists), and mylonites (foliated gabbros below), following Passchier and Trouw [1998]. Fault schists may record brittle (cataclastic) deformation, plastic deformation (e.g., syntectonic growth of crystals), or semibrittle deformation (e.g., cataclastic porphyroclasts in a fine- 
Table 3. Summary of XRD Mineral Identifications

\begin{tabular}{|c|c|c|}
\hline Sample $^{\mathrm{a}}$ & Description & Phases Identified ${ }^{\mathrm{b}}$ \\
\hline $\mathrm{BR} 22$ (pc 1a, $0 \mathrm{~cm})$ & Fault schist core & Talc \\
\hline $\mathrm{BR} 22(\mathrm{pc} 1 \mathrm{c}, 13 \mathrm{~cm})$ & Undeformed altered peridotite & Talc \\
\hline $\mathrm{BR} 23(5 \mathrm{~cm})$ & Fault schist core & Actinolite \\
\hline BR24 (pc 1,0-20 cm) & Fault schist fragment & Chlorite, hydrotalcite \\
\hline BR24 $(0-23 \mathrm{~cm})$ & Fault schist core & Chlorite (quartz, hydrotalcite) \\
\hline BR24 $(23-30 \mathrm{~cm})$ & Fault schist fragment & Chlorite (hydrotalcite) \\
\hline BR25 (pc 3, 14-21 cm) & Fault schist fragment & Talc, chlorite \\
\hline BR25 $(14-21 \mathrm{~cm})$ & Fault schist fragment & Talc, chlorite \\
\hline BR26 $(9 \mathrm{~cm})$ & Fault schist fragment & Chlorite, talc, ferropargasite \\
\hline BR27 $(11-25 \mathrm{~cm})$ & Altered core (dolerite ?) & Chlorite \\
\hline BR27 $(15-17 \mathrm{~cm})$ & Alteration mud & Chlorite (quartz, calcite) \\
\hline BR28 $(0-8 \mathrm{~cm})$ & Fault schist fragment & Tremolite, actinolite \\
\hline $\operatorname{BR} 28(8-11 \mathrm{~cm})$ & Fault schist fragment (BR28A) & Actinolite, chlorite \\
\hline BR28 (pc 3b, 18-19 cm) & Fault schist core & Actinolite (crossite) \\
\hline BR29 (pc 2d, $54 \mathrm{~cm})$ & Fault schist fragment in sedimentary breccia & Tremolite (crossite, quartz) \\
\hline $\mathrm{BR} 32(3 \mathrm{~cm})$ & Fault schist fragment & Talc, chlorite, pargasite \\
\hline BR33 (0 cm) & Fault schist core & Talc, chlorite \\
\hline $\mathrm{BR} 34(\mathrm{pc} 3,15 \mathrm{~cm})$ & Undeformed gabbro & Anorthite, augite, saponite, talc \\
\hline BR36 (pc 2, 34-36 cm) & Breccia in contact between dolerite dykes (?) & Talc, chlorite, actinolite \\
\hline $\mathrm{BR} 37(\mathrm{pc} \mathrm{5d}, 51 \mathrm{~cm})$ & Fault schist fragment in sedimentary breccia & Talc, chlorite \\
\hline BR39 (pc 2b, 29) & Fault schist fragment in sedimentary breccia & Talc, actinolite \\
\hline $\mathrm{BR} 40(\mathrm{pc} 1 \mathrm{~b}, 8 \mathrm{~cm})$ & Fault schist core (BR40D) & Talc, chlorite, actinolite \\
\hline $\mathrm{BR} 40(\mathrm{pc} 1 \mathrm{~b}, 11 \mathrm{~cm})$ & Fault schist core & Amphibole, chlorite \\
\hline $\mathrm{BR} 40(\mathrm{pc} 2 \mathrm{~B}, 17 \mathrm{~cm})$ & Fault schist core & Chlorite, tremolite \\
\hline BR40 $(66-74 \mathrm{~cm})$ & Fault schist fragment (BR40E) & Chlorite, actinolite \\
\hline BR41 (pc 4, $13 \mathrm{~cm})$ & Fault schist fragment & Actinolite, chlorite \\
\hline $\mathrm{BR} 43$ (pc 3, $33 \mathrm{~cm})$ & Fault schist fragment & Actinolite, chlorite \\
\hline $\mathrm{BR} 45(\mathrm{pc} 1,3 \mathrm{~cm})$ & soft pale highly sheared serp & Chlorite, actinolite, talc \\
\hline $\mathrm{BR} 45(\mathrm{pc} 13,77-84 \mathrm{~cm})$ & Fault schist fragment & Talc, actinolite, chlorite \\
\hline $\operatorname{BR} 46(6-16 \mathrm{~cm})$ & Fault schist fragment & Chlorite, talc \\
\hline BR47 (pc 5, $29 \mathrm{~cm})$ & Fault schist fragment & Talc \\
\hline BR50 (pc 2a, $1 \mathrm{~cm})$ & Vein in serpentinized dunite & Chrysotile, talc, calcite/dolomite \\
\hline BR50 (pc 7a, $48 \mathrm{~cm})$ & Serpentinized dunite & Lizardite, diopside \\
\hline $\mathrm{BR} 54(\mathrm{pc} 1,5 \mathrm{~cm})$ & Fault schist in dolerite core & Actinolite, chlorite \\
\hline BR55 (pc 2, $5 \mathrm{~cm})$ & Vein in serpentinized peridotite & Talc, chrysotile \\
\hline BR60 $(23 \mathrm{~cm})$ & Mud from serpentinized harzburgite & Lizardite \\
\hline BR61 (pc 3c, $15 \mathrm{~cm})$ & Mesh-textured serpentinized peridotite & Lizardite \\
\hline BR63 $(0 \mathrm{~cm})$ & Fault schist core & Actinolite \\
\hline BR64 $(4 \mathrm{~cm})$ & Fault schist fragment & Actinolite, chlorite \\
\hline BR65 $(17 \mathrm{~cm})$ & Fault schist fragment & Talc \\
\hline BR67 $(7-18 \mathrm{~cm})$ & Fault schist fragment & Chlorite, talc \\
\hline BR70 $(0-27 \mathrm{~cm})$ & Fault schist fragment & Talc (chlorite) \\
\hline $\operatorname{BR} 71(3-12 \mathrm{~cm})$ & Fault schist fragment & Talc, actinolite \\
\hline BR76 (pc 1c, $23 \mathrm{~cm})$ & Fault schist in dolerite core & Chlorite, actinolite \\
\hline BR78 (pc 3, 28-30 cm) & Serpentinized dunite & Lizardite, talc, chlorite \\
\hline BR79 $(0-13 \mathrm{~cm})$ & Fault schist fragment & Actinolite, Chlorite \\
\hline BR86 (pc 4, 17-22 cm) & $\begin{array}{l}\text { Carbonate vein cutting serpentinized peridotite } \\
\text { core near contact with dolerite }\end{array}$ & Calcite, talc \\
\hline BR86 (pc 4, 17-22 cm) & Serpentinized peridotite core near contact with dolerite & Talc (chlorite, tremolite) \\
\hline BR86 $(23-32 \mathrm{~cm})$ & Fault schist fragment (BR86B) & Chlorite, talc, actinolite \\
\hline BR90 $(18 \mathrm{~cm})$ & Fault schist fragment & Actinolite, chlorite \\
\hline BR90 (pc 7a, $26 \mathrm{~cm})$ & Fault schist core (BR90-A) & Actinolite, chlorite \\
\hline BR91 (pc 1a, $0 \mathrm{~cm})$ & Fault schist core & Talc, chlorite \\
\hline DR12-1 & Fault schist & Actinolite, chlorite \\
\hline DR12-3 & Green alteration & Chlorite \\
\hline DR13-1 & Fault schist fragment & Talc, chlorite \\
\hline DR13-4 & Fault schist fragment & Talc, chlorite \\
\hline DR13-9 & Fault schist, fibrous & Chrysotile \\
\hline DR14-4 & Fault schist fragment & Talc, actinolite, chlorite \\
\hline DR14-Bag 4 & Fault schist fragment & Talc, actinolite, chlorite \\
\hline
\end{tabular}



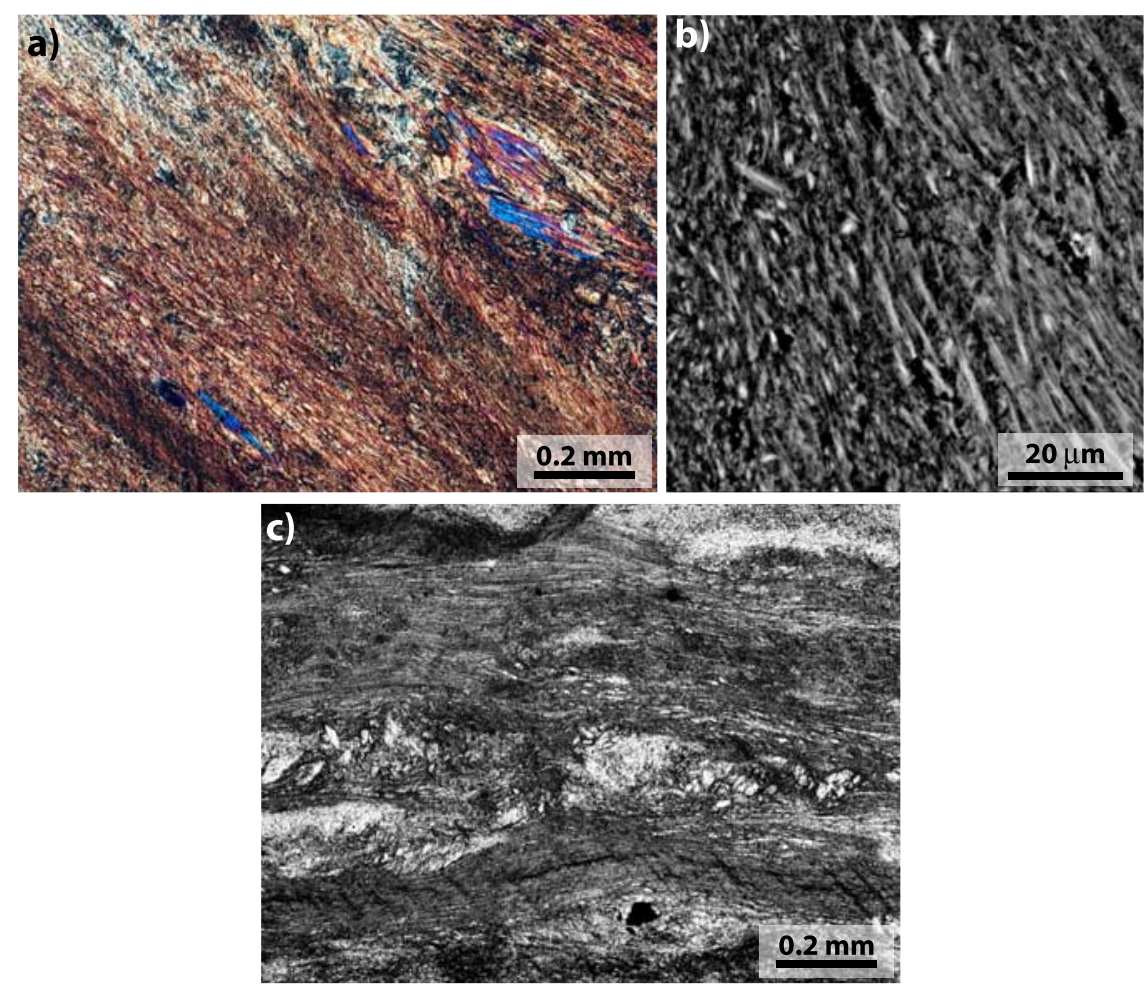

Figure 7. (a) Fine-grain amphibole mylonite with well-developed schistosity, and incorporating rotated amphibole crystals. (b) Detail of the fine-grain amphibole matrix, with well-oriented grains typically $<10 \mu \mathrm{m}$ in length. (c) Zones of pre-existing amphibolite reworked within the shear zone. All micrographs from BR28A (Table 2).

grain matrix of syntectonically grown minerals). Mylonites are characterized by strong grain-size reduction due to ductile deformation at high temperature, as observed in some mylonitic gabbro samples.

\subsubsection{Fault Schists}

[27] Schistose fault rocks were dredged and drilled primarily along the detachment fault itself, or at the higher levels of flanking scarps, in the immediate vicinity of the striated surface (Figure 3d). These rocks are most commonly associated with diabase, as described above (Figures 3-5). Some of the cores drilled on basement at the top of the south east knoll, and near striated outcrops identified in near-bottom images [MacLeod et al., 2002, Figure 2], show in an intense sub-horizontal schis- tosity sub-parallel to the detachment fault (e.g., BR22 and BR23, Figure 4), and record intense deformation, as seen both on the hand specimens and the optical and electron microscope images.

[28] Fault schists are composed mainly of amphibole (tremolite and/or actinolite), talc, or a mixture of both, although occasionally serpentinite schists are also found (e.g., DR13-17 or DR13-9 in XRD analyses in Table 3). Chlorite is present in most samples, as well as relict spinels, oxides and opaques (mineral identifications from XRD, optical microscope observations, electron microprobe and SEM compositional images, Figures 7-9). Two types of fault schists have been identified on the basis of optical and SEM microstructural observations.

[29] The first type of fault schist shows welldeveloped foliation, and has a very fine-grained

\footnotetext{
Notes to Table 3

${ }^{a}$ The sample number corresponds to those in Tables 1 or 2 . When applicable, the piece number and the position in the core (depth in cp) is also given in parenthesis.

${ }^{\mathrm{b}}$ The phases reported are in order of abundance as estimated from XRD analyses. Minor mineral phases are in parenthesis.
} 

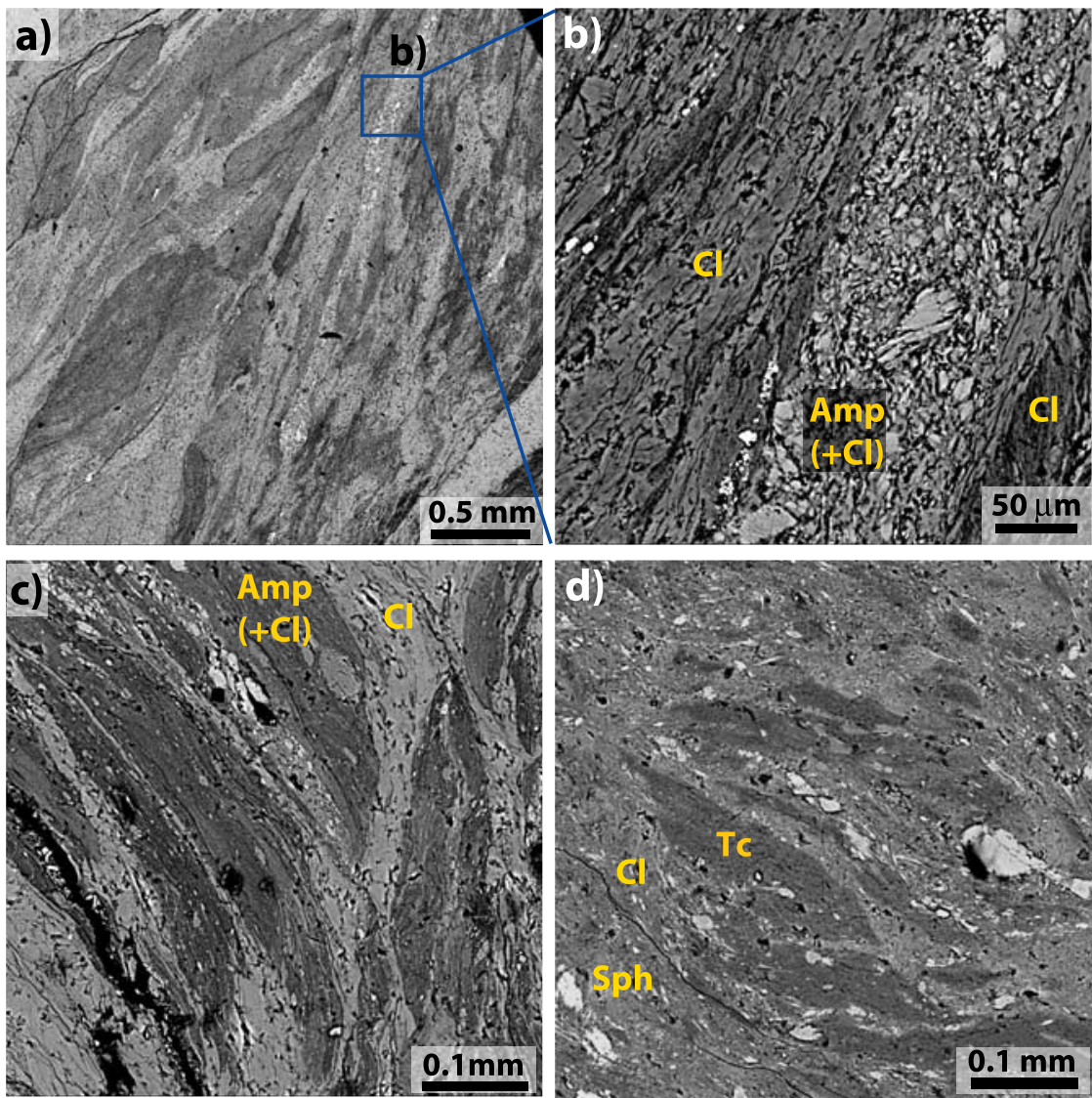

Figure 8. (a) Fault schist showing sigmoidal zones of amphibole + chlorite (dark lens-shaped areas) surrounded by chlorite-rich bands (light grey areas) and bands of cataclastic amphibole grains (lighter bands, detail in Figure 8b). (b) Band of fine-grain amphibolite clasts within foliated chlorite bands (sample BR40E, Figure 4). (c) Sigmoidal bands of amphibolite surrounded by chlorite and containing clasts of amphibole crystals and other accessory minerals (BR40A, Figure 4). (d) Sigmoidal bands of talc surrounded by chlorite and containing cataclastic porphyroclasts of sphene and other minerals (sample BR71C, Figure 4).

matrix $(<10-100 \mu \mathrm{m})$ of syntectonically-grown minerals (mainly amphibole, Figures $7 \mathrm{a}$ and $7 \mathrm{~b}$, or talc and chlorite). This matrix embeds brittlely reworked porphyroclasts of amphibole grains and of amphibole schist in the fault zone, defining elongated areas parallel to, and draped by the foliation of the matrix (Figure 7c). None of the amphibole porphyroclasts show kinking or bending, and show clear solid rotation of individual grains and cataclastic grain size reduction $(0.2 \mathrm{~mm}-10 \mu \mathrm{m}$, Figures $7 \mathrm{a}$ and $7 \mathrm{c}$ ). Fibrous veins crosscut the schistosity at high angles. These veins record vein opening that is coeval with the formation of the matrix schistosity, as shown by amphibole fibers that are sub-perpendicular to cracks at their core, and that curve toward the edges of the vein where they show continuity with the matrix schistosity.
[30] The second type is composed of amphibole, talc, or a combination of both, with less-developed schistosity, and is characterized by a complex microtexture with sigmoidal bands of syntectonically-grown amphibole and/or talc and cataclastic bands (Figure 8). These latter microstructures record a complex history of deformation, with both reworking of fault rock and syntectonic growth of talc or amphibole. The sigmoidal zones, which define a weak and irregular foliation, are composed of amphibole/talc and chlorite (Figures 8a and $8 \mathrm{c}-8 \mathrm{~d})$ and display homogenous optical extinction (Figure $5 \mathrm{~b}$ ). Thin $(<1 \mathrm{~mm})$ chlorite-rich zones with well-developed foliation drape the sigmoidal clasts. Clasts of amphibole and talc schist $(<1 \mathrm{~mm})$ show internal foliation that is at high angle to the overall schistosity, indicating solid rotation and reworking 

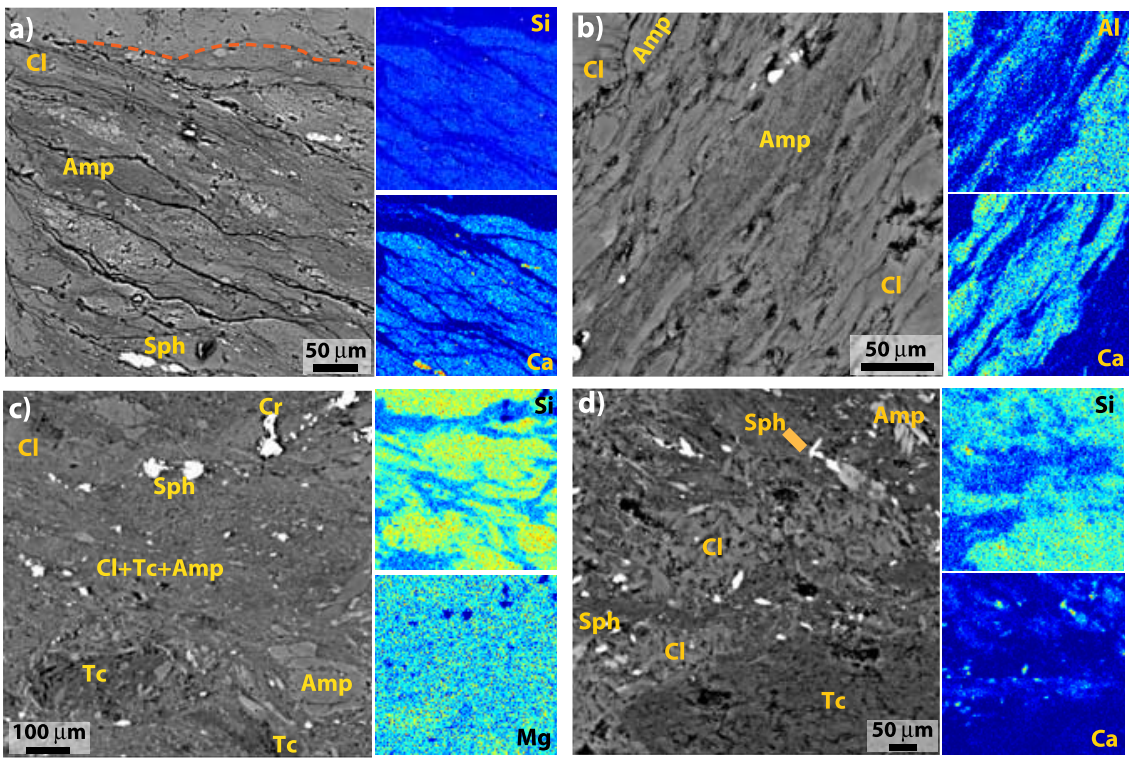

Figure 9. SEM micrographs and selected element distribution maps of fault schists. (a) Fault rock composed of amphibole (high Si and Ca concentrations) and chlorite in contact with diabase (BR40A, same micrograph as in Figure 5c). (b) Gradual compositional variations within the shear zone, with chlorite- and amphibole-rich zones (BR40E, Figure 4). Clorite- and amphibole-rich zones alternate at scales of $<25 \mu \mathrm{m}$. (c) Irregular patches of talc- and chlorite + amphibolite-rich zones in a talc schist (BR71B, Figure 4). (d) Late chlorite patches with radial habit overprinting talc schist (BR71C, Figure 4). These irregular patches are also found in amphibolite-rich schists (see brown patches in Figure 5b). All samples show minor amounts of Ca-rich sphene ( $\mathrm{Sph})$.

of previously existing fault schists (e.g., Figure 8). SEM images show porphyroclasts of variable sizes (down to $<50 \mu \mathrm{m}$ ) both distributed throughout the amphibole/talc-rich sigmoidal areas, and concentrated in narrow bands $(\sim 100 \mu \mathrm{m}$ or less, Figures $8 \mathrm{a}$ and $8 \mathrm{~b}$ ) of very finely crushed clasts. The porphyroclasts are composed, in order of abundance, of amphibole and amphibolite schists, sphene, chromite, oxides and spinel (Figure 9). These microstructures record a complex history of phases of ductile and brittle deformation.

[31] Optical microscope observations and SEM element analysis demonstrate the syntectonic intergrowth of amphibole and talc with chlorite. Anomalous blue chlorite (Figure 5b) is oriented parallel to the foliation draping around the sigmoidal clasts (light areas in Figures $8 \mathrm{a}-8 \mathrm{c}$ ), or alternate with amphibole- and chlorite-rich areas at scales of $0.1 \mathrm{~mm}$ to $<50 \mu \mathrm{m}$ (Figures $9 \mathrm{a}-9 \mathrm{c}$ ). Some fault schists are cross cut by late-stage brittle cracks accommodating small amounts of strain. Irregular patches $(<2 \mathrm{~mm})$ of brown chlorite (Figure 9d) with a radial habit demonstrate that these rocks underwent post-tectonic, static chloritization.

\subsubsection{Foliated Gabbro}

[32] One dredge with a few gabbro mylonite samples was recovered on the east flank of the southeast knoll (DR23-1, Figures 3d and 10). These gabbros show and alternation of highly deformed zones with well-developed foliation and compositional banding at $<1 \mathrm{~cm}$ scale. The foliation is defined by alternating bands of pyroxene, brown amphibole and plagioclase, indicating grain size reduction (pyroxene), dynamic recrystallization (plagioclase) and syntectonic crystal growth (amphibole; Figure 10). Zones with relict magmatic textures show large plagioclase and pyroxene crystals with recrystallization along their boundaries. Some of these foliated rocks have sharp boundaries and are in direct contact with highly fractured and altered gabbro (Figure 10b). These high-temperature amphibolite facies shear zones appear to overprint lower temperature pseudomorphic alteration, and are cross cut by undeformed ferrohornblende and plagioclase veins. Amphiboles both in shear zones and veins are chlorite-rich, suggesting involvement of seawater-derived brines in the deformation zone. Gabbro mylonites have also 

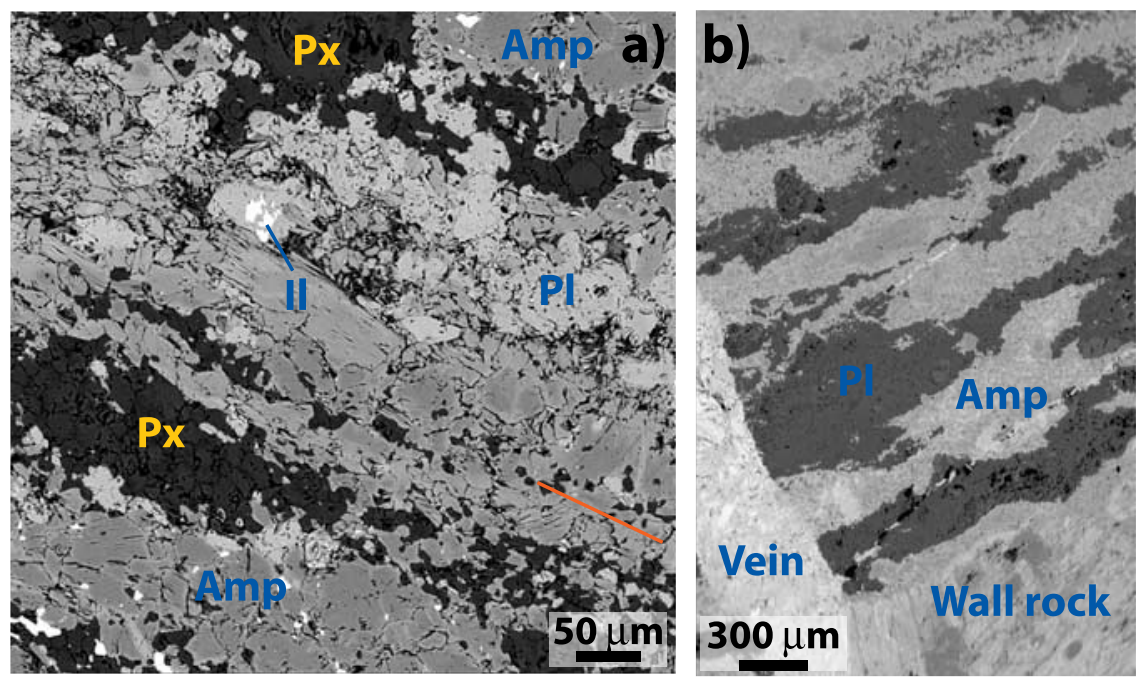

Figure 10. (a) SEM micrograph of foliated gabbro with alternating bands of amphibole (Amp), pyroxene (Px) and plagioclase $(\mathrm{Pl})$, indicating deformation at $\mathrm{T}>700^{\circ} \mathrm{C}$ (see text; DR23-1, Figure 3d and Table 1). Accessory ilmenite (Il) is also present. (b) Gabbro with plagioclase-amphibole foliation in contact with rock wall and crosscut by amphibole vein (DR23-4, Table 1).

been sampled during the MODE'98 Dive 422 from the base of the south flank of the southeast knoll [M. Braun, personal communication; Matsumoto et al., 1998]. Mylonitic gabbros are therefore a very rare occurrence volumetrically, are restricted solely to two sites, and we cannot establish any direct spatial association of these samples with the detachment fault.

\section{Results}

\subsection{Fault Schist Protolith}

[33] The bulk-rock compositions of the fault schists (talc, amphibole, serpentinite, and chlorite) are not consistent with those of any primary rock from the ocean lithosphere (basalt, gabbro, peridotite) and suggest important chemical remobilization during deformation and alteration. Despite the obliteration of primary textures and chemical composition by metamorphic crystallization, it is nevertheless possible to conclude that the fault rocks derive mainly from ultramafic rocks based on: (1) the composition of the small spinel grains that have been preserved during mylonitization, and (2) the bulk composition of serpentinized peridotites, gabbros, and fault schists. There is evidence for some contribution of gabbro or diabase/basalt in the fault zone, but this component appears to be very minor or negligible.

[34] Figure 11a clearly shows that the composition of small chromian spinel porphyroclasts found in both amphibole and talc fault schists have $\mathrm{Cr} \#$ and $\mathrm{Mg} \#$ consistent with those measured in spinels from serpentinized peridotites in this area, or with values reported for oceanic ultramafic peridotites [e.g., Dick and Bullen, 1984] (Table A1 in Appendix). Only an altered spinel grain shows $\mathrm{Cr} \#$ and $\mathrm{Mg} \#$ values well outside the ultramafic peridotite domain. These compositions demonstrate that spinel clasts in fault schists have an ultramafic origin.

[35] The bulk compositions of two fault rocks (talc and serpentine schists) have been compared with those of two undeformed serpentinized peridotites and of two diabases. Major element abundances (Table 4) show that the serpentinite fault rock has a bulk composition consistent with that of undeformed serpentinite, while the talc-schist is very enriched in silica. The rare earth elements (REE), however, yield very low concentrations for both fault rocks, similar to those of serpentinized peridotites recovered in the area (Figure 11b) and other ultramafic rocks. REE concentrations in the diabases are an order of magnitude or more higher. As REEs are not normally mobilized during alteration 

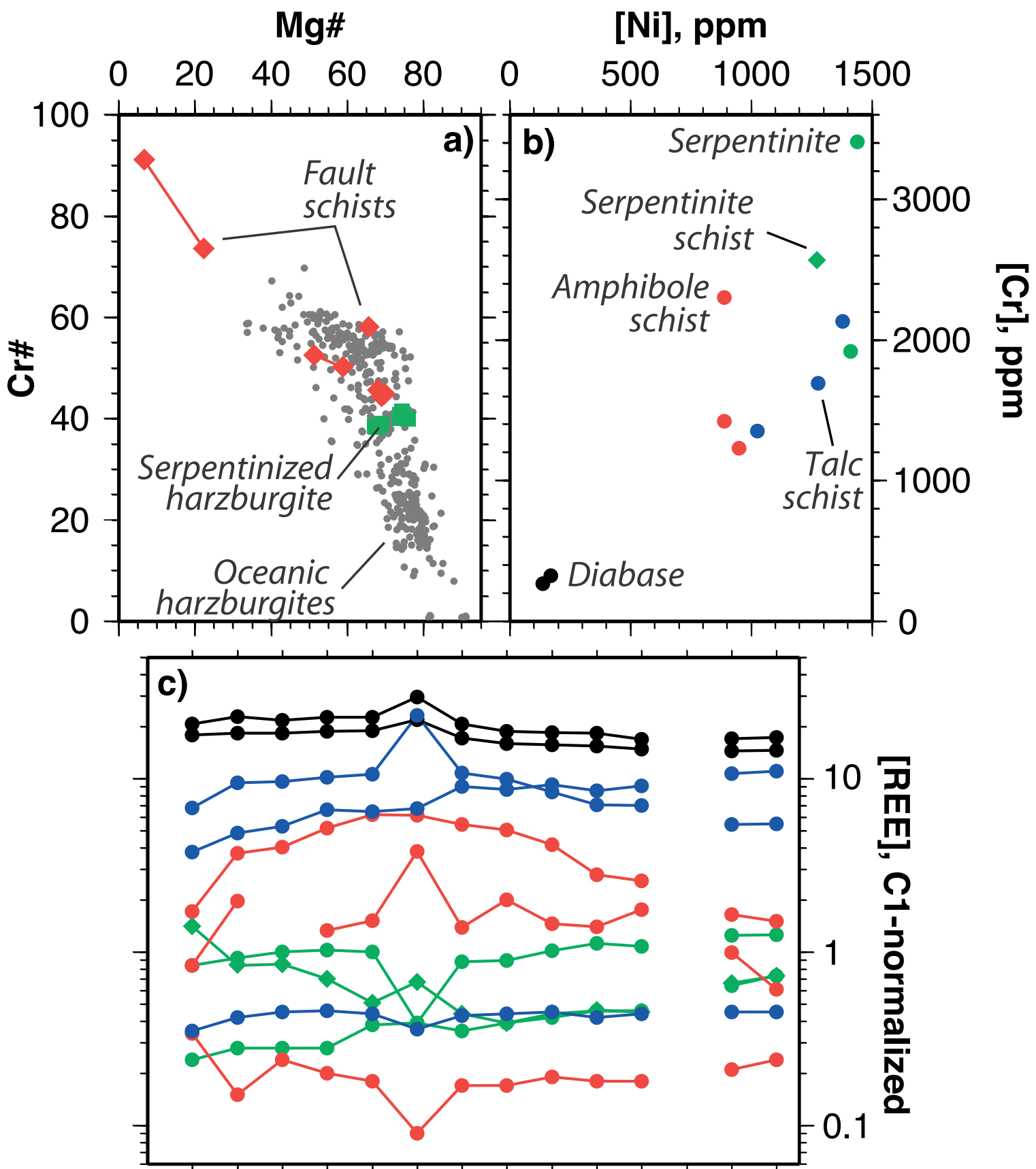

\section{La Ce Pr NdSmEu Gd Tb Dy H Er Tm Yb Lu}

Figure 11. (a) Spinel compositions. With the exception of an altered sample, spinel grains within the fault rocks (red) have compositions consistent with those of spinels from serpentinized harzburgites both from the same detachment (green) and from other oceanic peridotites (grey dots). Symbols joined by a line correspond to multiple measurements at the same grain. Data for oceanic peridotites from RidgePetroDB [Lehnert et al., 2000]. Spinel composition analyses are given in Table A2 of the appendix. (b) Bulk-rock concentration of Ni vs. Cr of selected samples. Talc and amphibolite schists show [Ni] and [Cr] concentrations between those of serpentinites and diabase. (c) Bulk-rock rare earth element (REE) normalized concentrations for amphibolite and talc schists, serpentinized peridotites, and diabase (same color convention as in Figure 11b). Both the $[\mathrm{Ni}] /[\mathrm{Cr}]$ and REE data indicate that the amphibolite and talc schists have an ultramaphic protolith, with varying amounts of diabase/gabbro component. Whole rock analyses are given in Table A4 of the appendix. 
processes, the REE patterns further support the conclusion from the spinel compositions that the protolith is ultramafic. Microstructural observations demonstrate that diabase both intrudes into, and is deformed by the shear zone and incorporated into it (Figure 6). In the samples studied so far the volume of magmatic rocks incorporated into the protolith must be negligible so as not to increase the REE concentrations significantly above those typical of ultramafics. The presence of sphene in some samples may indicate that gabbro or diabase dykelets cross cutting the ultramafic protolith, as commonly observed in abyssal peridotites from the Mid Atlantic Ridge [e.g., Mével et al., 1991; Cannat et al., 1992], were deformed and recrystallized together with the enclosing peridotite. Alternatively, diabase dykes emplaced in the detachment may have been deformed and recrystallized.

\subsection{Composition of the Footwall}

[36] Detachments expose sub-surface levels of the oceanic lithosphere, and their detailed sampling provides constraints on the composition and distribution of lithologies within the footwall, in addition to information on deformation processes along the fault. Sampling is uneven and irregular along the detachment fault, but shows that gabbros are mostly found at the southeast knoll, where sampling was concentrated (elsewhere, the only occurrences are two dredges at the north edge of the detachment, Figure 3b). Peridotite, diabase and basalt, on the other hand, are found throughout the detachment surface (Figure 3).

[37] Close examination of the well-sampled southeast knoll indicates that gabbros are not directly exposed along the fault surface, but crop out structurally below the detachment itself. To study the vertical distribution of lithologies relative to the irregular detachment surface, we have estimated the relative position of each drill and dredge with respect to the fault surface as identified in the bathymetry and side-scan sonar images (shaded area in Figures 2 and 3). We have restricted our analysis to the rectangular area shown in the detailed maps in Figure 3 (bottom), because of the higher sampling density there, but the more limited sampling of other parts of the detachment indicate similar relationships. An indicative relative maximum depth of a sample below the detachment surface is calculated from the difference between the depth of the detachment surface at the closest point and the actual depth at which the sample was recovered (Figure 3, bottom). Dredge data are not located as precisely as the drill sites, but we have included them in our analysis assuming that lithologies dredged occur along the whole length of the dredge path. These samples may correspond to rubble shed from outcrops at higher levels, and therefore the calculated depths below the detachment are also a maximum estimate. The data were binned at 50-m intervals, as shown in the histograms in Figure 12. These data clearly show that most of the gabbro outcrops occur at depths of $\sim 500 \mathrm{~m}$ below the detachment surface, with scarce occurrences in the immediate vicinity of the detachment fault. Diabase, peridotite and fault rocks outcrop preferentially along the detachment surface, and are present but scarce at deeper levels. These data indicate that the fault zone associated with the detachment is very thin, as fault rocks are found mainly within $<100 \mathrm{~m}$ of the striated surface. The two hightemperature mylonitic gabbro occurrences reported in this study (see section 5.4 Fault rocks) and in Matsumoto et al. [1998] are well below the detachment fault surface ( $>100$ and $\sim 500 \mathrm{~m}$, respectively).

\subsection{Deformation Along the Detachment, Magmatism, and Fluid Circulation}

[38] The macro- and microstructural observations of the fault rocks, the relationships between the different lithologies at individual cores or throughout the detachment, and their composition, provide constraints on: (1) the conditions of deformation along the detachment fault; (2) the relationship between deformation and magmatism associated with the emplacement of the diabases; and (3) the required fluid-rock interactions that result in the alteration of the ultramafic protolith into talc and/or amphibole schists.

\subsubsection{Conditions of Deformation Along the Detachment Faults}

[39] Because of the nature of the mineral assemblages of the fault schists, it is not possible to 


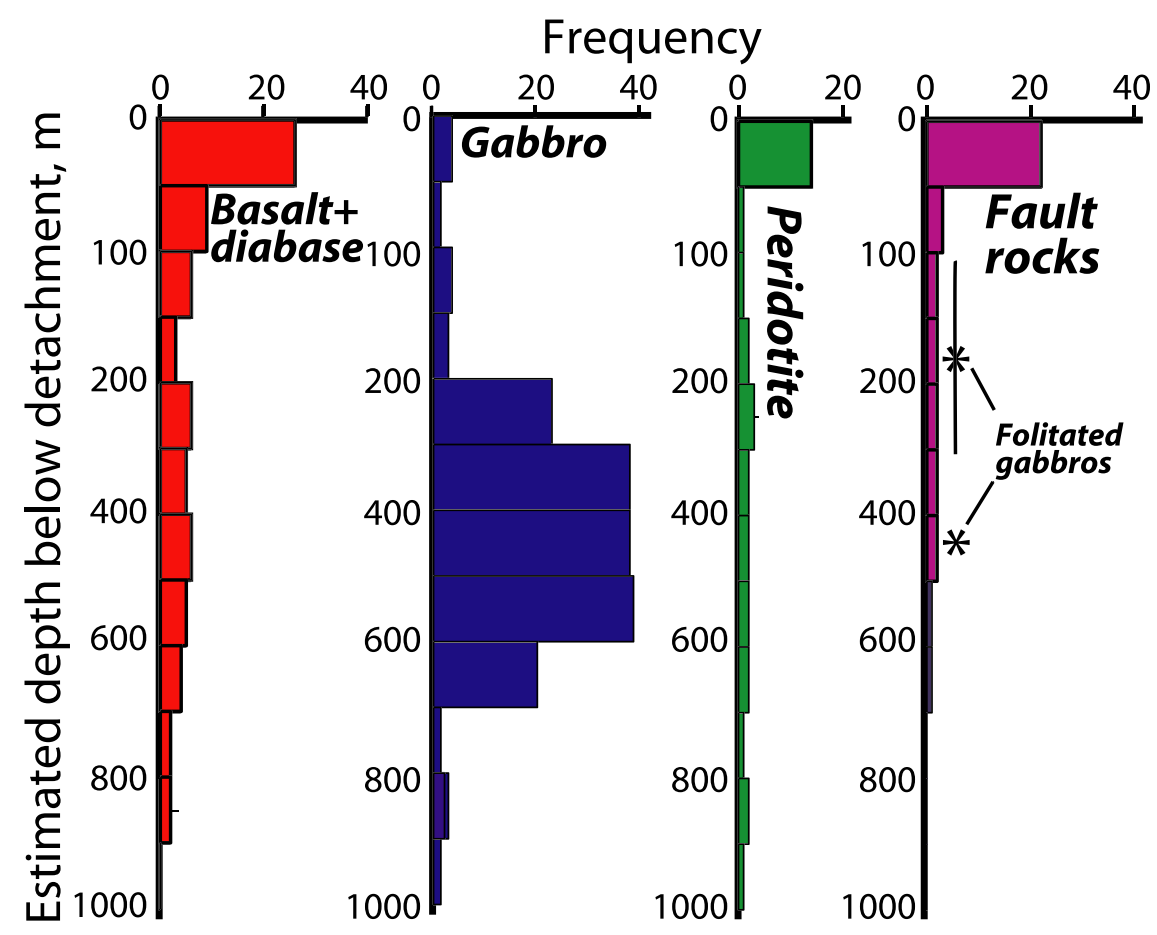

Figure 12. Vertical distribution of lithologies relative to the fault surface from the detailed maps at bottom of Figure 3. Depth below the detachment is the difference between the actual depth of the sample and that of the preserved detachment surface at the closest point. Despite the sampling bias of the detachment surface, it is clear that gabbros outcrop well below the detachment surface $(\sim 500 \mathrm{~m})$, and the detachment fault zone as defined by the occurrence of schists is thin $(<100 \mathrm{~m})$. Data include both drills and dredges, for which we assume that litholigies outcrop all along the dredge track and for each $50 \mathrm{~m}$ depth bin. Totals for each rock type are thus larger than the combined number of drills and dredges shown in the maps.

determine the temperature of formation of the fault rocks precisely. The presence of tremolite-actinolite (Figure 13), and the intergrowth of chlorite with amphibole and talc (Figure 9) suggest that these rocks formed under greenschist facies conditions, at temperatures $<500^{\circ} \mathrm{C}$ and possibly lower than $300^{\circ} \mathrm{C}$ [e.g., Miyashiro, 1973]. Furthermore, amphiboles have $\mathrm{Ti}$ and $\mathrm{Al}$ contents consistent with temperatures of formation $<500^{\circ} \mathrm{C}$ [Ernst and Liu, 1998]. These minerals grew syntectonically, defining the schistosity described above. Both the brittle reworking of pre-existing amphibole/talc schists into the shear zone and the similar chemical composition of reworked clasts and matrix minerals indicate a single deformation event and stable chemical composition of fluids within the fault zone during deformation.

[40] Evidence of plastic deformation in the fault rocks is scarce. High-temperature plastic deforma- tion is only recorded by mylonitic gabbro recovered in a single dredge (DR23-1), in addition to one reported occurrence at the southeast flank of the detachment (Figures 2, 3d, and 10). The syntectonic recrystallization of plagioclase and amphiboles (hornblende to pargasitic and edenitic hornblendes) in the mylonitic gabbros appears to be in equilibrium. Using the composition of plagioclase-amphibole pairs on the two samples shown in Figure 10, the geothermometer of Holland and Blundy [1994] yields temperatures of $\sim 720-750^{\circ} \mathrm{C} \pm 40^{\circ} \mathrm{C}$ at low pressures. We have no field or microstructural evidence to link the greenschist facies deformation along the detachment fault, and the high-temperature deformation of the foliated gabbros. None of the microstructural observations suggest overprinting of high-temperature deformation structures by low-temperature ones other than veins. Moreover, the scarcity of mylonitic gabbro samples suggests that they may form very localized shear zones (i.e., 


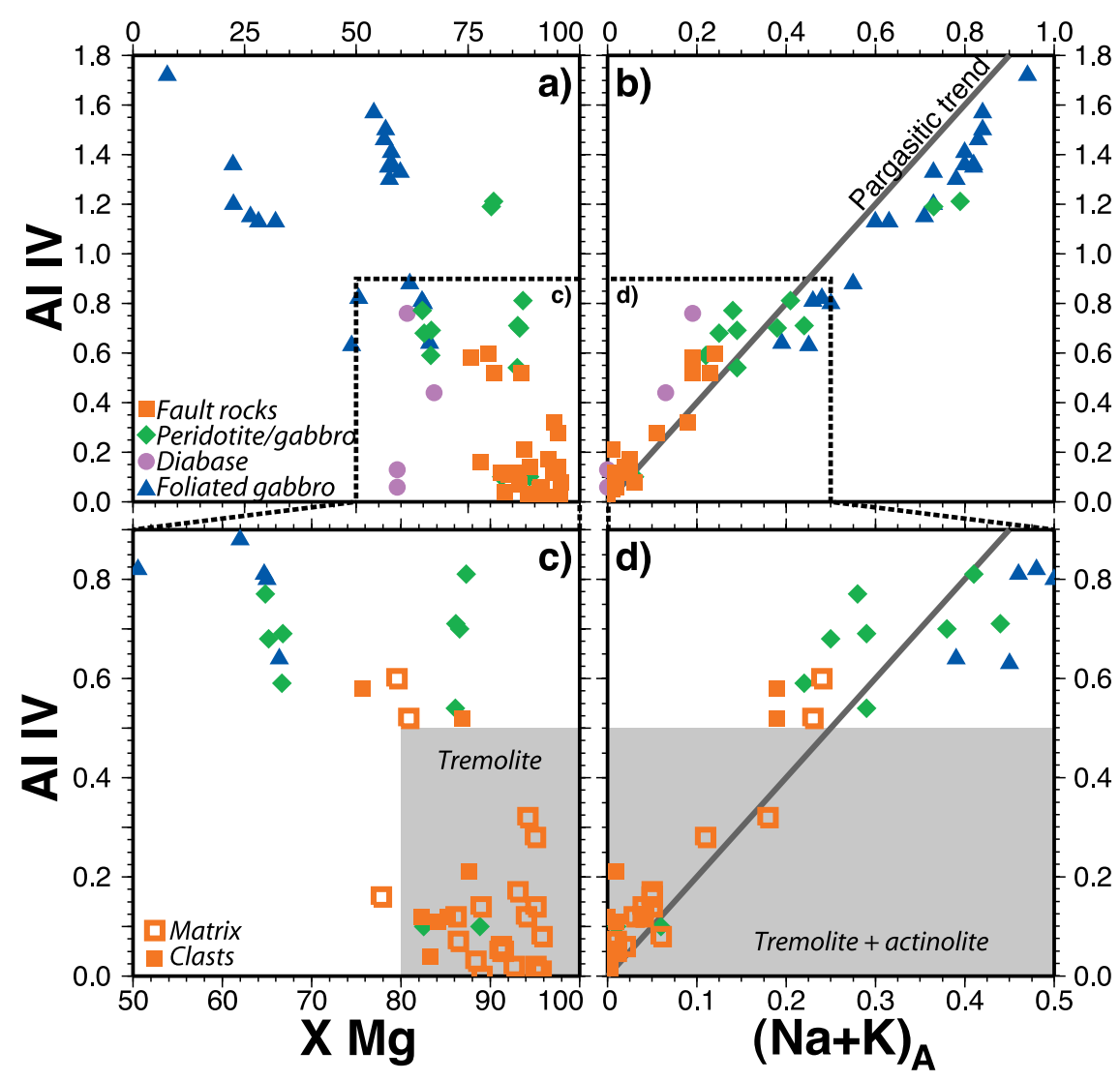

Figure 13. Amphibolite chemical compositions. Amphiboles in the foliated gabbro samples show elevated Al IV values $(\mathrm{a}, \mathrm{b})$ while amphiboles from rocks sampled along the detachment fault have Al IV values $<0.8$ in addition to low $\mathrm{Mg}, \mathrm{Na}+\mathrm{Ka}$. There is no clear difference between matrix amphiboles grown syntectonically and those in clasts reworked within the shear zone (c, d). All amphiboles analyzed follow the pargasite trend (b, d). Analyses are given in Table A2 of the appendix.

formed in cooling gabbro bodies or during emplacement in the lithosphere) unrelated to the detachment fault, although we cannot be ruled out completely that this deformation may be associated with it.

[41] The shear zones crosscutting statically-serpentinized peridotites prior to deformation (Figure 6) demonstrate that fault rocks developed at temperatures well below $500^{\circ} \mathrm{C}$ (perhaps as low as $300^{\circ} \mathrm{C}$ [e.g., O'Hanley, 1996]). The paragenesis of the rock does not provide any constraints on the maximum depth of deformation.

[42] We have no constraints on the depth of deformation recorded by the mineral assemblages or the microstructures of the deformed rocks. Instead, we can obtain some depth estimates from the thermal structure predicted by models of slow spreading ridge segments. Using the "NMARL" model of Shaw and $\operatorname{Lin}$ [1996], the $500^{\circ} \mathrm{C}$ isotherm (limit of the greenschist facies) may vary in depth between $\sim 7.5$ and $3.5 \mathrm{~km}$ along the axis and immediately below it. These thermal models do not incorporate detachment faults, which may substantially affect the thermal state of the lithosphere. Lacking any other constraints, the maximum depth of deformation recorded by the detachment may occur at in the lithosphere depths of $<7 \mathrm{~km}\left(\mathrm{~T}<500^{\circ} \mathrm{C}\right)$.

\subsubsection{Relations Between Deformation and Magmatism Along the Detachment}

[43] Both the drilled and the dredged samples display apparent intrusive relationships of the diabases into the shear zone (e.g., Figure 5a). Diabases, however, are also deformed within the shear 


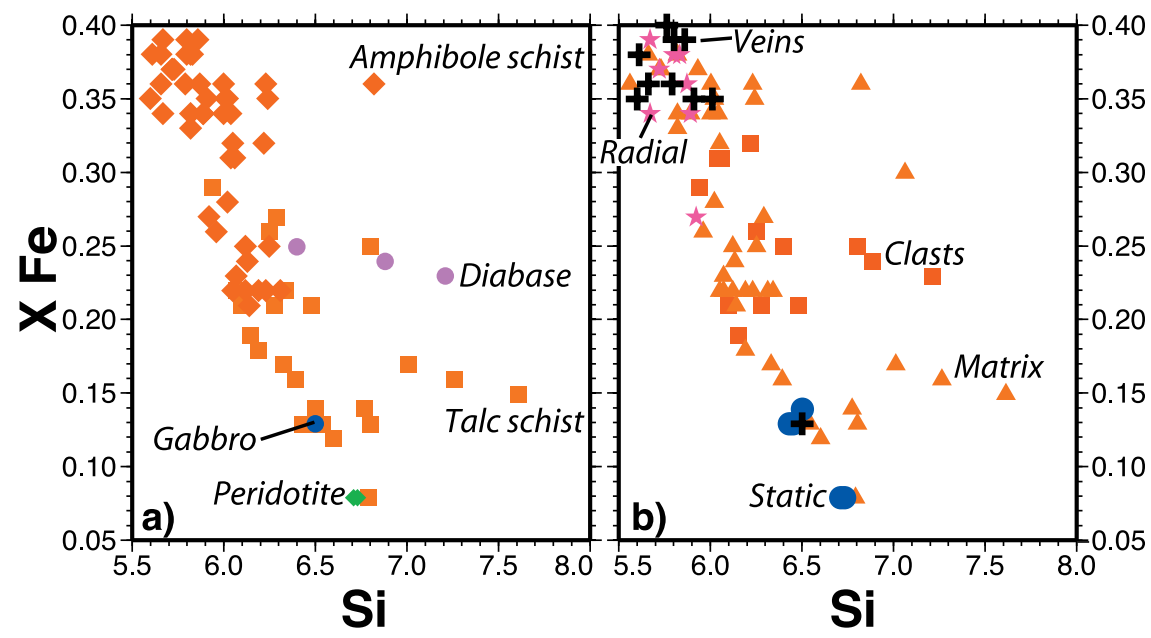

Figure 14. (a) Chlorite chemical composition. Amphiboles from talc schists have lower X Fe and higher Si values. (b) As in the case of amphiboles, there is no difference between chlorite intergrown with amphibole and talc in the fault rocks. Late stage chloritization, indicated by irregular patches with radial chlorite and static chloritization, show different compositions. Analyses are given in Table A3 of the appendix.

zone, as they occur as small clasts or thin deformed $(<5 \mathrm{~cm}$ levels embedded within the sheared rocks (Figures 4 and $5 b-5 c$ ). These observations indicate that deformation is coeval with the diabase injection. As there is no record of off-axis volcanism along slow-spreading ridges, we infer that magmatism occurred at the ridge axis, and therefore the detachment fault was active below the rift valley. Dyke intrusions cross-cutting the fault zone were probably restricted spatially and separated in time so as to allow the mechanical continuity of the detachment required for ongoing deformation under the ridge axis. Frequent or continuous dyke injections would crosscut the detachment fault and arrest its development, as suggested in previous models of oceanic detachment faulting [e.g., Tucholke et al., 2001].

\subsubsection{Fluids, Alteration and Deformation}

[44] The presence of fluids along the detachment fault zone during deformation is required, strongly altering the chemical composition of the protolith. Important enrichments of silica and, to a lesser degree, of calcium are required to allow the crystallization of both talc and tremolite, respectively. Silica enrichment can result both from silica input by the fluid phase, or by a loss of magnesium and other elements during recrystallization. Chlorites show a compositional evolution, with a progressive enrichment in $\mathrm{Fe}$ (Figure 14) in the later chloritization events (veins and radial patches, Figure 9). This may indicate either a progressive enrichment in iron of the fluids circulating along the fault zone, or a phase of chloritization post-dating the deformation of the detachment, with Fe-rich fluids unrelated to those within the fault zone. Fluids within the fault zone probably developed high pore fluid pressures at moderate to low temperatures, as indicated by the dilatant amphibole veins crosscutting the schistose foliation. Flow rates were probably high in order to allow the alteration of the protolith and the mobilization of elements, but additional oxygen isotope work (in progress) is required to better constrain fluid volumes and fluxes required to form the synkinematic assemblages reported.

[45] Experimental work by Allen and Seyfried [2003] demonstrates that at $\mathrm{T} \sim 400^{\circ} \mathrm{C}$ and $\mathrm{P} \sim$ 500 bar pyroxene is altered preferentially over olivine, as forsterite remains stable. The resulting fluid phase is enriched in $\mathrm{Ca}, \mathrm{SiO}_{2}, \mathrm{Fe}$ and $\mathrm{H}_{2}$. An increased silica activity in the fluid phase results in the stability of talc or tremolite, depending on the $\mathrm{Ca}$ activity, rather than serpentine. The widespread abundance of talc and amphibole in detachment fault rocks could therefore result from focused flow 
a) Shallow detachment (15 45' N, MAR)

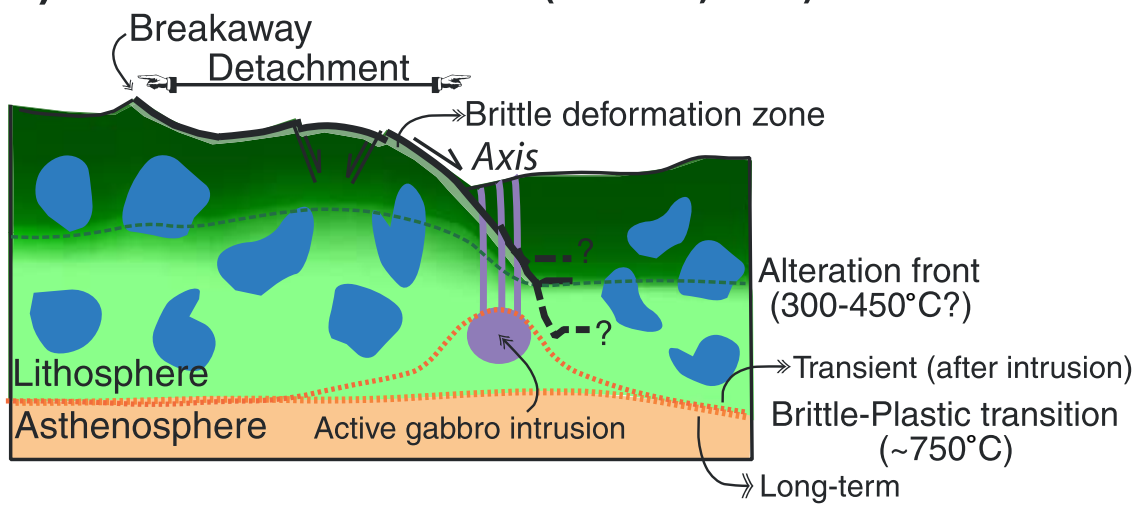

b) Amagmatic extension

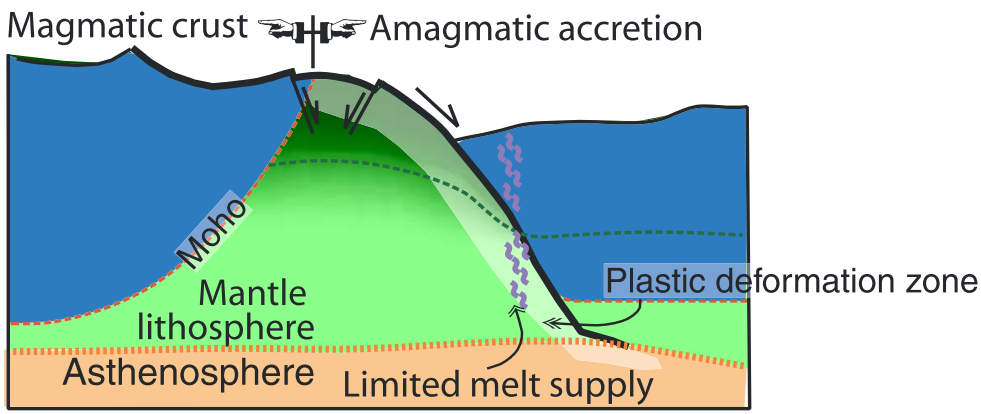

\section{c) Melt-assisted extension}

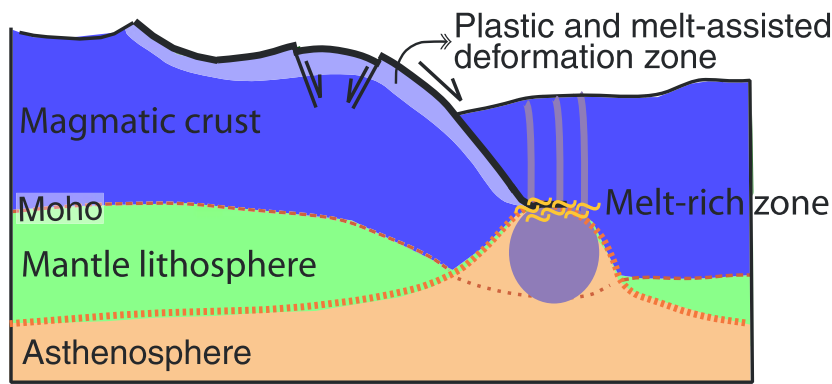

Figure 15. Proposed models for oceanic core complexes. (a) We propose a model of a detachment fault rooting in the shallow lithosphere. The alteration front may correspond to a rheological boundary between the altered (weak) and unaltered (strong) lithosphere. Magmatic intrusions may result in transient variations of the thermal structure, affecting the depth of the brittle-ductile transition. (b) Previous models propose a detachment rooting at the base of the lithosphere. The onset of amagmatic extension results in detachment faulting and the formation of a detachment that accretes lithospheric mantle and exposes the deep lithosphere [Tucholke et al., 1998, 2001]. (c) Alternative models propose a detachment fault rooting at or near a melt-rich zone near the ridge axis [Dick et al., 2000]. A continuous magmatic crust is formed during detachment faulting, which exposes mainly gabbros that are deformed at high temperatures and in the presence of melt.

along the detachment of fluids discharging from deeper levels of the fault zone. These fluids may have either interacted with peridotites at temperatures $>350^{\circ} \mathrm{C}$, with basaltic rocks, or with both. Fluids that interacted with ultramafic rocks at lower temperatures would not have the required $\mathrm{Si}$ and $\mathrm{Ca}$ contents, and would produce serpentinerich assemblages within the fault zone. Fault rocks therefore record localized fluid flow, as required to alter its original ultramafic composition, suggesting 
a) Stage 1

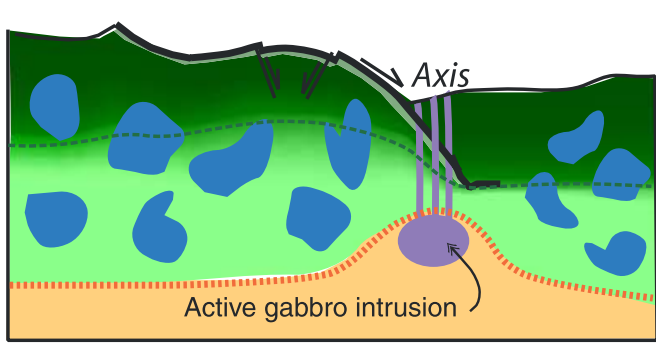

b) Stage 2

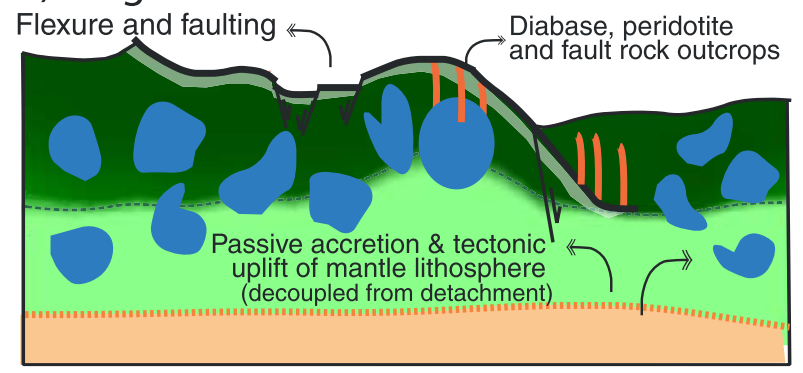

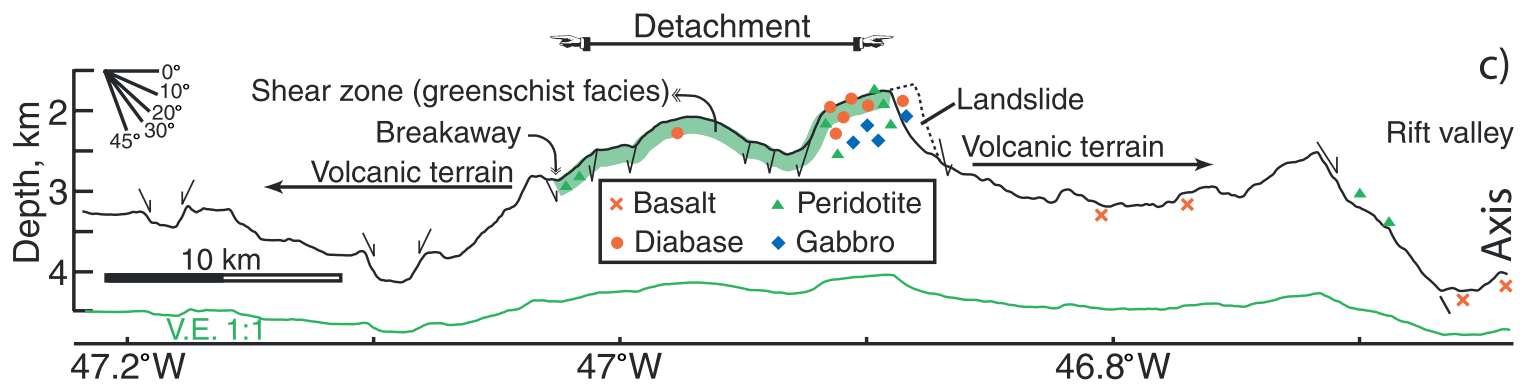

Figure 16. (a, b) Temporal evolution of a shallow detachment and (c) present-day configuration of the detachment. Extension along the detachment is coeval with intrusions and dyke injection across the fault zone (Figure 16a). Continued extension results in flexure and faulting of the exposed detachment fault. Mantle rocks are uplifted from the base to the shallow lithosphere, and later exposed by the detachment (Figure 16b). Bathymetric profile across the detachment (V.E. 1:3.33; see Figure 2a for location), and relative position of sampled lithologies (Figure 16c). The same profile with no vertical exaggeration is also shown at the bottom (green line).

that the fault zone may have been a discharge zone for hydrothermal fluids.

\section{Discussion}

[46] On the basis of the results presented above, we present a model for the evolution of the oceanic detachment at $15^{\circ} 45^{\prime} \mathrm{N}$, comparing the predictions of the model with observations elsewhere, and with models published previously (Figures 15 and 16).

\subsection{Detachment Fault Model at the Mid-Atlantic Ridge at $15^{\circ} 45^{\prime} \mathrm{N}$}

\subsubsection{Deformation Along the Detachment Fault and Magmatism}

[47] The results presented above indicate that the detachment fault was active in a cold (and probably shallow) lithosphere, with no evidence of rooting into deep lithospheric levels. On the basis of these results, we propose a model for an oceanic detachment (Figure 15a) and its evolution (Figure 16). First, mylonitic gabbros deformed at high temper- atures $\left(>700^{\circ} \mathrm{C}\right)$ occur only locally, were recovered at a single dredge site (an additional occurrence is reported from a previous cruise [Matsumoto et al., 1998]), and are located structurally well below the detachment surface (Figure 12). Evidence for hightemperature plastic- or melt-assisted deformation in the footwall rocks is practically non-existent, and we cannot associate deformation at high temperature identified locally to deformation along the detachment fault. Second, the fault rocks sampled along the striated surface record low to moderate temperatures of deformation (within the greenschist facies), consistent with active detachment faulting in the shallow and cold lithosphere, with no evidence of high-temperature deformation microstructures overprinted by low-T ones. Samples of serpentinized peridotite crosscut by talc shear zones which grade into undeformed talc growing after serpentinite demonstrate that peridotites were already serpentinized when deformed. In addition, talc and amphibole are alteration products of ultramafic protolith, which only occur along the detachment fault. As footwall rocks in the imme- 
diate vicinity of the detachment do not show these alteration phases, we infer that fluid flow was effectively restricted to the fault zone. Finally, there is almost no evidence of plastic deformation in serpentinites as most of them preserve the microstructures of static serpentinization (i.e., bastites). Little evidence of any earlier higher temperature plastic deformation has been found. As serpentinites are extremely weak [e.g., Reinen et al., 1993; Moore et al., 1997; Escartín et al., 1997a], deformation of serpentinized peridotites associated with the detachment occurred probably at $\mathrm{T}<300^{\circ} \mathrm{C}$ or less, within the brittle regime. Deformation was localized very efficiently along the detachment fault since the footwall rocks are mostly undeformed.

[48] Development of a detachment fault requires effective localization of deformation over long periods of time. Several models have invoked the presence of a rheological boundary at depth that guides stresses and fixes deformation. This boundary has been identified as the brittle-plastic transition in continental and oceanic detachments [e.g., Wernicke, 1990; Davis and Lister, 1988; Tucholke et al., 2001] and in analogue models [Brun et al., 1994; Gartell, 1997; Mulugeta and Ghebreab, 2001] (Figure 15b), or as melt-rich zones within the lithosphere [e.g., Dick et al., 1991, 2000; Lister and Baldwin, 1993; Parsons and Thompson, 1993] (Figure 15c). Experimental studies have shown that low degrees of serpentinization $(<15 \%)$ substantially reduce the strength of strong peridotites to that of weak serpentine [Escartín et al., 2001], indicating that the alteration front may correspond to a transition from strong, unaltered to weak, altered oceanic lithosphere. This rheological boundary within the brittle lithosphere could serve as a horizon for detachments to sole out (Figures 15a and $15 \mathrm{~b})$. The detachment may also root above this alteration front or below it (Figure 15a). If rooting is within the altered lithosphere, we do not have any mechanism that may fix deformation at this location during long periods of time (i.e., no rheological boundary). Rooting at deeper levels may be possible, but we do not have any observations that may support this model. In all cases, the geometry of the detachment is unconstrained.
[49] Effective localization of deformation is likely to be assisted by the presence of weak minerals and fluids along a very thin fault zone. The mechanical properties of talc, chlorite and serpentinite [e.g., Reinen et al., 1991; Escartín et al., 1997a; Moore et al., 1997] suggest that fault schists containing these minerals are considerably weaker. While no rheological data exists on amphibolite compositionally schists similar to those described here, the similarity of the deformation microstructures with those of the talc and serpentinite schists (Figures 4 and 7-9), and the presence of weak chlorite suggests that these rocks are also very weak. Presence of fluids within the fault zone, as required to form the mineral assemblages described, together with the mode of deformation of some hydrous silicates [Escartín et al., 1997b], can further reduce the effective confining pressure and hence the strength of the fault.

[50] If the detachment was indeed initiated in the relatively shallow lithosphere, the exposures along the detachment fault surface record shallow magmatic processes in a heterogeneous lithosphere, and do not necessarily expose deep sections of the oceanic lithosphere. The presence of numerous deformed and undeformed diabase intrusions along the fault surface indicates an interaction of the active detachment fault with axial magmatism (Figure 15a). Chilled margins in diabase (Figure 4) indicate that the lithosphere and the fault zone were cold during their emplacement, consistent with temperatures recorded by fault rock mineral assemblages. The lack of basalt over the detachment faults indicates that no magmatism took place while the inactive detachment fault was exposed at the seafloor off-axis, and that the extrusives were very effectively carried away by the hanging wall (Figure 16). These diabases may correspond to the melts extracted from the gabbros below the detachment, although no geochemical evidence is yet available to establish possible this link. Alternatively, melts could have been transported laterally by dyke propagation along the ridge axis while the detachment was active.

[51] Long-lived detachment faulting and coeval magmatism suggest an important temporal variability in the thermal structure in the shallow 
lithosphere. Gabbro bodies probably intruded a cold lithosphere, resulting in important and local variations of temperatures. The spatial distribution and duration of gabbro emplacement must have been limited so as to allow continued deformation along the fault zone (Figure 15a). The size of the gabbro outcrop sampled is relatively small $(<5 \mathrm{~km}$ in diameter), consistent with spatial variations in lithologies observed along the rift valley walls at $15^{\circ} \mathrm{N}$ [Cannat et al., 1997]. The geological evidence recovered here is consistent with that of previous studies in the same area [Cannat and Casey, 1995; Cannat et al., 1997; Lagabrielle et al., 1998], which suggest that the formation of a compositionally heterogeneous lithosphere [e.g., Cannat, 1993] occurred while the detachment was active (Figures 15a and 16a-16b). Although the amount of magmatism cannot be quantified with the existing data, magmatic accretion was not continuous. Sustained dyke injections across the fault zone would have dissected the detachment at depth below the ridge axis, disrupting its mechanical continuity, and resulting in its termination.

\subsubsection{Geometry of the Detachment Fault}

[52] The morphology of the detachment fault records a history of flexure and related high-angle faulting. The along-axis large-scale undulations and the bathymetric corrugations (Figure 2) have been maintained by the fault over a long period of time, suggesting that they are inherited from deepseated irregularities of the fault [e.g., Jackson and White, 1989; Tucholke et al., 1998], and are similar to those observed at continental detachments [e.g., Spencer, 1984; Wright et al., 1974; John, 1987]. The observations presented here do not support other proposed mechanisms that require plastic deformation, such as folding of the fault surface at depth [e.g., Spencer, 1984; Fletcher et al., 1995], or continuous casting [e.g., Spencer, 1999].

[53] Flexure of the exposed fault is evident from the undulations of the detachment surface along the spreading direction, defining a low at the centre of the detachment, from the irregular faults bounding this central depressed section, and from the shallow tilt away from the axis of parts of the detachment (see Figures 2 and 16c). Rollover models of low- angle [Wernicke and Axen, 1988] or steeply dipping faults at depth [e.g., Buck, 1988; Lavier et al., 1999] predict important flexure of the footwall. Part of the strain associated with plate flexure is accommodated by high-angle normal faults that dissect the exposed, inactive portion of the detachment fault (Figure 2). The detachment is terminated to the east by a high-angle normal fault with a vertical throw of $>1.5 \mathrm{~km}$ (Figures 2 and 16) that we interpret as a former rift-bounding wall. Flexural response to large normal faults can result in $>10^{\circ}$ of tilt [e.g., Shaw, 1992], and can account for the detachment fault dipping slightly away from the ridge axis (Figure 16c). The detailed geometry or the fault at depth and the mode of dissipation of the deformation at the fault root are also unconstrained. Finally, detachment faults may not be stable in time and excise material from the footwall or hangingwall due to changes in position. While unsampled strands of a complex detachment fault may exist below the exposed fault surface, none of the samples structurally below the detachment show the fault-related assemblages that may be expected.

\subsubsection{Deformation of the Lower Lithosphere}

[54] We have no evidence of a direct link between the shallow deformation recorded by the detachment fault rocks, and the deeper deformation processes operating near the brittle-plastic transition required to expose mantle rocks at the seafloor (Figure 16b). Exposure of serpentinized peridotites at the nearby ridge axis (Figure 2) has been explained by a network of crosscutting shear zones that uplifts material from the top of the asthenosphere to the seafloor through the whole thickness of the lithosphere right below the ridge axis [e.g., Cannat et al., 1997; Lagabrielle et al., 1998]. The dominance of undeformed over deformed rocks from possible shear zones suggests that deformation is highly localized along shear zones, leaving a large portion of the lithospheric material undeformed. The specific deformation mechanisms, or the geometry of this tectonic lift is not constrained nor properly understood. In the absence of any additional information, we propose that a similar 
mode of tectonic uplift operated in the lithosphere below the detachment while it was active below the ridge axis, as the peridotites and the nature of deformation that they record are comparable to those reported from the ridge axis. Alternatively, deformation at the base of the detachment fault may be more distributed over a broad area. Therefore the link between the detachment and lower lithosphere deformation is unconstrained, lacking both geological and geophysical constraints. However, we cannot rule out that the detachment may continue into deep lithosphere or even the upper asthenosphere, and its geometry (i.e., steep versus shallow dipping fault at depth) is unknown.

\subsection{Comparison With Existing Models of Oceanic Detachments}

[55] Two alternative models have been previously proposed to explain large detachment surfaces observed along the Mid-Atlantic Ridge and the South West Indian Ridge. Both models propose rooting of the detachment fault in a rheological boundary, but their geological predictions on the mode of deformation, nature of exposures and distributions of lithologies do not fully agree with our observations. The first model invokes amagmatic extension during detachment faulting (Figure 15b), and the second continuous magmatic supply with direct feedback between the detachment fault and the magmatic system (Figure 15c).

\subsubsection{Amagmatic Extension and Detachment Faulting}

[56] Tucholke et al. [1998, 2001] proposed that detachment faults cut through the whole thickness of the lithosphere, soling out at the brittle-plastic transition at its base. In this model detachment faults develop during periods of amagmatic accretion when the lithosphere is cold and the isotherms depressed. These faults are terminated when magmatic activity raises the isotherms and normal magmatic accretion of oceanic crust is reinitiated. This model has been developed from morphological characteristics, geological observations, and relatively sparse sampling of tectonic structures along the Mid-Atlantic Ridge that are similar to the one at $15^{\circ} 45^{\prime} \mathrm{N}$ described here [Tucholke et al.,
1997, 1998, 2001]. All these structures show corrugated, striated and domed surfaces that are structurally continuous, with gabbros and peridotites found along their surface in association with diabase, the occurrence of serpentine and other fault schists, and with a lack of evidence for widespread high-temperature deformation of the footwall rocks. Many of these detachments show large areas covered with basaltic rocks, including pillow lavas (e.g., Dante's Dome [Tucholke et al., 2001] and Atlantis massif [Cann et al., 1997; Blackman et al., 1998]), which are absent from the detachment surface at $15^{\circ} 45^{\prime} \mathrm{N}$. Most of these basalts may have been rafted from the hanging wall along the exposed and inactive detachment fault at the seafloor, as suggested by the presence of tectonic klippens at the Atlantis massif [Cann et al., 1997; Blackman et al., 1998], or erupted directly onto the fault surface in close proximity to the ridge axis [Tucholke et al., 2001].

[57] The model of oceanic detachment faults rooting in ductile levels is closely related to that developed for continental core complexes. Continental detachments are characterized by a wide $(>250 \mathrm{~m})$ zone of pervasive ductile deformation, and a progressive localization of the deformation with a transition to brittle deformation overprinting the previous ductile fabric [e.g., Miller et al., 1983; Bykerk-Kauffman and Janecke, 1987; Lee and Lister, 1992; Mueller and Snoke, 1993]. Although high-temperature ductilely deformed peridotites and gabbros have been sampled in proximity to oceanic detachments [e.g., Cannat et al., 1992; Jaroslow et al., 1996; Karson, 1999], they are mainly sampled along nearby transform valley walls and are probably associated with the transform fault instead of detachment faulting, although there is little information on the orientation of such deformation zones. As observed at $15^{\circ} 45^{\prime} \mathrm{N}$, most of the recovered gabbros along these detachments are undeformed, and serpentinite and/or amphibole schists are common [e.g., Cann et al., 1997; Campbell-Stone et al., 2000; Tucholke et al., 2001; Reston et al., 2002; Dick et al., 2002], even when footwall rocks are sampled immediately below the detachment at scarps cross-cutting it (e.g., $5^{\circ} \mathrm{S}$ at the Mid-Atlantic Ridge [Reston et 
Table A1. Spinel Major Element Analyses

\begin{tabular}{|c|c|c|c|c|c|c|c|c|c|c|c|c|}
\hline Sample & $\mathrm{IP}^{\mathrm{a}}$ & $\mathrm{SiO}_{2}$ & $\mathrm{TiO}_{2}$ & $\mathrm{Al}_{2} \mathrm{O}_{3}$ & $\mathrm{Cr}_{2} \mathrm{O}_{3}$ & $\mathrm{Fe}_{2} \mathrm{O}_{3}$ & $\mathrm{FeO}$ & $\mathrm{MnO}$ & $\mathrm{MgO}$ & Total & $\mathrm{Cr} \#$ & $\mathrm{Mg} \#$ \\
\hline BR40E-1 & 27 & 1.81 & 0.82 & 2.83 & 42.66 & 15.81 & 31.83 & 0.90 & 1.31 & 97.96 & 91.00 & 6.83 \\
\hline BR40E-1 & 28 & 6.78 & 0.53 & 8.08 & 33.48 & 6.91 & 32.04 & 0.49 & 5.20 & 93.51 & 73.53 & 22.43 \\
\hline $86 \mathrm{~A}-4$ & 33 & 0.02 & 0.23 & 26.85 & 40.22 & 2.06 & 16.00 & 0.39 & 12.86 & 98.63 & 50.12 & 58.89 \\
\hline $86 \mathrm{~A}-4$ & 35 & 0.04 & 0.11 & 24.54 & 40.45 & 1.40 & 18.13 & 0.11 & 10.72 & 95.50 & 52.51 & 51.34 \\
\hline DR13-23-1 & 40 & 0.00 & 0.06 & 29.96 & 36.38 & & 15.82 & 0.13 & 15.73 & 98.08 & 44.89 & 69.86 \\
\hline DR13-23-1 & 41 & 0.05 & 0.06 & 30.45 & 36.21 & & 15.59 & 0.16 & 15.56 & 98.09 & 44.37 & 69.03 \\
\hline DR13-23-1 & 42 & 0.04 & 0.09 & 30.01 & 37.37 & & 15.56 & 0.21 & 15.36 & 98.64 & 45.51 & 68.09 \\
\hline DR13-3-4 & 0 & 0.00 & 0.08 & 22.96 & 47.29 & & 14.50 & 0.25 & 14.35 & 99.43 & 58.01 & 65.62 \\
\hline DR14-5-1 & 81 & 0.06 & 0.06 & 35.31 & 33.51 & & 13.64 & 0.18 & 17.47 & 100.22 & 41.41 & 74.41 \\
\hline DR14-5-1 & 82 & 0.08 & 0.05 & 33.32 & 33.77 & & 12.74 & 0.34 & 17.47 & 97.77 & 39.82 & 76.04 \\
\hline DR14-5-1 & 83 & 0.04 & 0.00 & 34.96 & 34.11 & & 13.31 & 0.10 & 17.28 & 99.78 & 40.74 & 73.80 \\
\hline DR14-5-1 & 84 & 0.07 & 0.04 & 33.35 & 33.38 & & 13.35 & 0.06 & 16.88 & 97.13 & 40.12 & 73.77 \\
\hline DR2-9-6 & 26 & 0.06 & 0.07 & 35.42 & 32.82 & & 14.20 & 0.10 & 15.59 & 98.25 & 38.32 & 67.63 \\
\hline DR2-9-6 & 27 & 0.01 & 0.04 & 35.49 & 32.99 & & 15.08 & 0.09 & 15.60 & 99.29 & 38.40 & 67.24 \\
\hline DR2-9-6 & 28 & 0.03 & 0.09 & 35.29 & 32.67 & & 14.47 & 0.25 & 15.71 & 98.50 & 38.31 & 68.25 \\
\hline DR2-9-6 & 29 & 0.00 & 0.06 & 35.08 & 33.39 & & 14.41 & 0.04 & 16.01 & 98.99 & 38.96 & 69.00 \\
\hline
\end{tabular}

${ }^{\mathrm{a}}$ Probe analysis number.

al., 2002]). Thus all these observations appear to be systematic and common to striated detachment surfaces identified along the Mid-Atlantic Ridge. Existing observations are not consistent with models rooting at or near the brittle ductile transition. First, there is no evidence of a wide zone of ductile deformation associated with these detachments, as may be expected if the fault rooted near or into the plastic deformation regime. Second, there is little evidence of widespread ductilely deformed rocks overprinted by low-temperature, brittle deformation, as would be expected if the deformation evolved from wide ductile shear zones at depth to narrow, more brittle deformation zones above the $\sim 500^{\circ} \mathrm{C}$ isotherm. Instead, these observations are more consistent with the model proposed above, in which the detachment fault does not reach deep lithospheric levels, but soles out in the cold lithosphere. We speculate that the fault may root near the alteration front, which may act as a rheological boundary, but we cannot fully rule out that rooting may take place below or above this alteration front (Figure 15a).

\subsubsection{Magmatic Extension and Detachment Faulting}

[58] An alternative detachment model proposes that the detachment fault soles out in a melt-rich, hot zone near the gabbro-dyke transition, also in the shallow lithosphere [Dick et al., 1991]. This model is based on geological observations at the Atlantis II Bank (South West Indian Ridge), which has been the target of two ODP legs drilling a $\sim 1500 \mathrm{~m}$ deep section of gabbro [Robinson et al., 1989; Dick et al., 1991, 2000, 2002], and systematic sampling with both dredges and wire line rock drilling [MacLeod et al., 1998]. The gabbros show a gradual decrease in deformation with depth, with ample evidence of sub-horizontal deformation fabrics, plasticity and melt-assisted deformation in the upper $250 \mathrm{~m}$ and along the surface of the Atlantis II Bank. These observations have been interpreted as evidence for a direct link of the detachment faulting into the axial magmatic system, most likely soling at the melt-rich gabbro-dyke transition. The detachment fault, while active, was an active part of the magmatic accretion system. Similar links between detachment faulting and magmatism have also been invoked to explain the origin of some low-angle continental faults [e.g., Anderson et al., 1988; Lister and Baldwin, 1993; Campbell-Stone et al., 2000].

[59] Atlantis Bank differs substantially in morphology from the striated and corrugated oceanic detachments described above. This detachment stands $\sim 5 \mathrm{~km}$ above surrounding seafloor, with a summit that has been wave-cut and subsequently subsided to a water depth of $\sim 700 \mathrm{~m}$ at the present time, indicating higher tectonic uplifts than any of the striated surfaces here or elsewhere [Tucholke et 
Table A2. Amphibole Major Element Analyses

\begin{tabular}{|c|c|c|c|c|c|c|c|c|c|c|c|c|c|c|c|c|c|}
\hline Sample & $I P^{\mathrm{a}}$ & ode $^{\mathrm{b}}$ & $\mathrm{iO}_{2}$ & $\mathrm{TiO}_{2}$ & $\mathrm{Al}_{2} \mathrm{O}_{3}$ & $\mathrm{Cr} 2 \mathrm{O}_{3}$ & $\mathrm{FeO}$ & $\mathrm{InO}$ & $\mathrm{MgO}$ & $\mathrm{CaO}$ & $\mathrm{Na}_{2} \mathrm{O}$ & $\mathrm{K}_{2} \mathrm{O}$ & Total & $\mathrm{KMg}$ & $\mathrm{XFe}$ & $\mathrm{Na}+\mathrm{K} \mathrm{A}$ & AlIV \\
\hline & 2 & C & & 0.00 & & 0.07 & & & & & 0.08 & 0.00 & 96.70 & 1.25 & & & .058 \\
\hline & 4 & $\mathrm{C}$ & & .07 & & & & 19 & & & 0.27 & & & 6.20 & 13.36 & & 0.117 \\
\hline R28A-2 & 5 & $\mathrm{C}$ & 3.18 & 0.10 & & 0.02 & 3.19 & 0.00 & & & 0.12 & & & & & & .016 \\
\hline R28A-2 & 6 & $\mathrm{C}$ & 6.43 & 0.03 & & 0.36 & & 0.08 & & & & & & & & & .144 \\
\hline R28A-1 & 10 & $\mathrm{C}$ & & 0.00 & & & & & & & & & & & & & .032 \\
\hline & & $\mathrm{C}$ & & 0.03 & & & 5.80 & & & & & & & & & & .070 \\
\hline & 1 & $\mathrm{C}$ & & 00 & & & 3.62 & & & & & & & & & & 052 \\
\hline & 3 & $\mathrm{C}$ & & 06 & & .06 & 3.81 & 0.09 & & 12.91 & & & & 91.09 & & & 046 \\
\hline & 4 & $\mathrm{~S}$ & & .00 & & & 6.62 & & .77 & 12.24 & & & & 4.18 & 82 & & .107 \\
\hline $8 \mathrm{~A}-1$ & 16 & $\mathrm{~S}$ & & .04 & & & & & & & & & & & & & .115 \\
\hline 40C-1 & 5 & $\mathrm{~S}$ & 5.93 & 0.07 & & 0.10 & 6.81 & 0.21 & 19.60 & 12.24 & & & & & & 00 & .038 \\
\hline & 6 & $\mathrm{C}$ & .83 & .12 & & 0.09 & & & & & & & & & & & .163 \\
\hline $\mathrm{C}-1$ & 7 & $\mathrm{C}$ & 2.44 & 0.05 & & 0.81 & 7.76 & & & 12.17 & & & & & & 33 & .518 \\
\hline 240C-4 & 26 & G & .57 & 0.38 & & & & & & & & & & & & & .694 \\
\hline & 7 & G & & .43 & & & & & & & & & & & & & 0.772 \\
\hline 40C-4 & 9 & G & & 0.40 & & & .25 & & & & & & & & & & .595 \\
\hline & & & & 0.43 & & & .65 & & & & & & & & & & .680 \\
\hline & & $\mathrm{C}$ & & 09 & & & & & & & & & & & & & 012 \\
\hline & & $\mathrm{C}$ & & .11 & & & & & & & & & & & & & 280 \\
\hline 10D-2 & 1 & $\mathrm{C}$ & & 0.03 & & & & & & & & & & & & & .143 \\
\hline 40D-3 & 4 & $\mathrm{C}$ & 5.60 & 0.08 & & & 2.37 & & 23.22 & & & & & & & & .323 \\
\hline & & $\mathrm{C}$ & .34 & 0.09 & & & & & & & & & & & & & .075 \\
\hline & 7 & $\mathrm{~S}$ & .05 & 0.18 & & & 5.42 & & 20.20 & & & & & & & & .523 \\
\hline & 0 & $\mathrm{~S}$ & .51 & 0.07 & & & 5.19 & & & & & & & & & & .210 \\
\hline & & $\mathrm{C}$ & .10 & 0.21 & & & & & & & & & & & & & .601 \\
\hline & & $\mathrm{P}$ & & & & & & & & & & & & & & & .131 \\
\hline & & $\mathrm{P}$ & & & & & & & & & & & & & & & 063 \\
\hline & & $S$ & & & & & & & & & & & & & & & .577 \\
\hline & & S & & & & & & & & & & & & & & & \\
\hline & & $\mathrm{S}$ & & & & & & & & & & & & & & 003 & .121 \\
\hline & 21 & $\mathrm{C}$ & & 00 & & & & & & & & & & & & & \\
\hline & & $\mathrm{C}$ & & .04 & & & & & & & & & & & & & \\
\hline & & $\mathrm{C}$ & .44 & .11 & & & & & & & & & & & & & 0.124 \\
\hline & & $\mathrm{C}$ & & 0.15 & & & & & & & & & & & & & .173 \\
\hline & 3 & $\mathrm{C}$ & & 0.04 & & & & & & & & & & & & 0 & .023 \\
\hline & & & & 0.21 & & & & & & & & & & & & & .439 \\
\hline & & $\mathrm{C}$ & & & & & & & & & & & & & & 0 & .003 \\
\hline & 41 & Px & & & & & & & & & & & & & & 195 & 0.763 \\
\hline & 15 & & & 04 & & & & & & & & & & & & & \\
\hline & 1 & & & & & & & & & & & & & & & & \\
\hline & 2 & & & & & & & & & & & & & & & & 105 \\
\hline & 3 & & & & & & & & & & & & & & & & 213 \\
\hline & 4 & & & & & & & & & & & & & & & & 195 \\
\hline & 21 & & & & & & & & & & & & & & & & 536 \\
\hline & 22 & & & & & & & & & & & & & & & & .709 \\
\hline & 23 & & & & & & & & & & & & & & & & .703 \\
\hline & 24 & & & & & & & & & & & & & & & & 806 \\
\hline & 25 & & & & & & & & & & & & & & & & 105 \\
\hline & 4 & & & & & & & & & & & & & & & & \\
\hline & & & & & & & & & & & & & & & & & \\
\hline & 45 & $\mathrm{P}$ & & 1.23 & & & & & & & & & & & & & .640 \\
\hline & 46 & $\mathrm{P}$ & & 1.28 & & & & & & & & & & & & & 0.804 \\
\hline & 47 & $\mathrm{P}$ & & 0.20 & 11.74 & & & & & & 2.20 & 41 & & & & & 1.715 \\
\hline & 48 & V & & 0.39 & & & & & & & & & & 26.25 & & & 1.147 \\
\hline $1-2$ & 50 & $\mathrm{P}$ & & & & & & 0.29 & 14.86 & & & & & 64.67 & & & 0.813 \\
\hline & 51 & V & & 0.2 & & & & & & & & & & & & & 1.196 \\
\hline & 52 & M & & & & & & 0 . & & & 1. & & & & & & 1.363 \\
\hline & 53 & M & & & & & & & & & & & & & & & 0.822 \\
\hline & 54 & M & & & & & & & & & & & & & & & \\
\hline & 55 & M & & & & & & & & & & & & & & & \\
\hline DR23-1-3 & 58 & $\mathrm{R}$ & 44.39 & 1.96 & 8.57 & 0.00 & 16.22 & 0.16 & 12.14 & 11.25 & 2.84 & 0.28 & 97.80 & 57.16 & 42.85 & 0.817 & 1.355 \\
\hline
\end{tabular}


Table A2. (Continued)

\begin{tabular}{|c|c|c|c|c|c|c|c|c|c|c|c|c|c|c|c|c|c|}
\hline Sam & $I P^{\mathrm{a}}$ & Mode ${ }^{b}$ & $\mathrm{SiO}_{2}$ & $\mathrm{TiO}_{2}$ & $\mathrm{Al}_{2} \mathrm{O}_{3}$ & $\mathrm{Cr} 2 \mathrm{O}_{3}$ & $\mathrm{FeO}$ & $\mathrm{MnO}$ & $\mathrm{MgO}$ & $\mathrm{CaO}$ & $\mathrm{Na}_{2} \mathrm{O}$ & $\mathrm{K}_{2} \mathrm{O}$ & Total & XMg & $\mathrm{XFe}$ & $\mathrm{Na}+\mathrm{K}$ A & AlIV \\
\hline & & & & & & & & & & & & & & & & & \\
\hline & & & & & & & & & & & & & & & & & \\
\hline & & $\mathrm{F}$ & & & & & & & & & & & & & & & .356 \\
\hline & 6 & & & 2.1 & & & & & & & & & & & & & .464 \\
\hline & & & & 2.24 & & & & & & & & & & & & & 1.504 \\
\hline & 68 & Pl & 43.80 & 2.19 & & & & 0.00 & & & 2.90 & & & & & & 1.411 \\
\hline DR23-1-5 & 71 & Pl & 42.58 & 2.31 & 10.55 & 0.01 & 16.36 & 0.10 & 10.75 & 11.36 & 3.01 & 0.33 & 97.36 & 53.93 & 46.07 & 0.844 & 1.574 \\
\hline
\end{tabular}

\footnotetext{
${ }^{\mathrm{a}}$ Probe analysis number.

${ }^{\mathrm{b}}$ S:, Matrix of shear zone; C, Clast; G, Amphibolite in gabbro clast; Px, Amphibolite after pyroxene; V, Vein; M, Fine-grain amphibolite matrix; P, Porphyroclast; Pl, Amphibole after altered plagioclase.
}

al., 1998, Table 1]. The detachment is a very narrow strip $\sim 10 \mathrm{~km}$-wide in a direction perpendicular to spreading, and records $>4$ M.y. of tectonic extension, with no clear bathymetric corrugations. In contrast, striated surfaces are almost equant or elongated in a direction parallel to the ridge axis, and record $<2 \mathrm{Ma}$ of tectonic extension. Finally, the abundance of gabbros, the scarcity of peridotites and diabase exposed along the fault surface, and the occurrence of a $>150 \mathrm{~m}$ thick zone with rocks plastically deformed and in the presence of melt, strongly points to a direct interaction of the detachment with the magmatic system over long periods of time [Dick et al., 1999; Natland and Dick, 2001]. Amphibolite and talc schists are also present at this location, probably capping the detachment [Dick et al., 2002]. These schists may correspond to fault rocks recording deformation in colder parts of the detachment away from the axial magmatic system, and are probably equivalent to those found at the $15^{\circ} 45^{\prime} \mathrm{N}$ MidAtlantic Ridge detachment as described above.

[60] On the basis of our observations and the comparison of our results with those of other oceanic detachments, we propose that oceanic detachments root at shallow levels in the lithosphere, either within the altered lithosphere or at the alteration front, or at a melt-rich zone at the gabbro-dyke transition. Morphologically, the resulting structures are substantially different as described above, although Atlantis II Bank is the only known example of 'magmatic' detachment. The abundance of diabase and gabbro along these detachment surfaces also demonstrates that these faults are active during ongoing magmatism, that amagmatic extension is not required for their functioning, and that detachment development will interact with magmatism during the construction of the footwall lithosphere. Finally, development of oceanic detachments is clearly assisted by tectonic stresses associated with nearby ridge discontinuities (transform and non-transform offsets), with which they are associated in most cases; compositionally heterogeneous lithosphere is commonly found at these locations. However, the presence of discontinuities is not required, as the detachment at $15^{\circ} 45^{\prime} \mathrm{N}$ is not located near any significant transform or non-transform offset.

\section{Conclusions}

[61] The striated and corrugated surface at $15^{\circ} 45^{\prime} \mathrm{N}$ off the axis of the Mid-Atlantic Ridge corresponds to a thin $(<150 \mathrm{~m})$ oceanic detachment fault composed of greenschist facies fault rocks (mainly amphibolite and talc schists derived from an ultramafic protolith), and outcropping peridotite, diabase and minor amounts of gabbro and basalt. Footwall rocks are mostly undeformed serpentinized peridotites and gabbros crosscut by diabase dykes, and show static alteration with no or very little evidence of plastic- or melt-assisted deformation that may be associated with the detachment. Limited sampling at other corrugated surfaces along the Mid-Atlantic Ridge yields the same lithologies, again lacking a record of high-T deformation. These observations suggest that the detachment fault did not sole out near or at the brittle-ductile transition, as suggested by some geological models of oceanic detachments. Instead 
Table A3. Chlorite Major Element Analyses

\begin{tabular}{|c|c|c|c|c|c|c|c|c|c|c|c|c|c|}
\hline Sample & $\mathrm{IP}^{\mathrm{a}}$ & Mode $^{\mathrm{b}}$ & $\mathrm{SiO}_{2}$ & $\mathrm{TiO}_{2}$ & $\mathrm{Al}_{2} \mathrm{O}_{3}$ & $\mathrm{Cr} 2 \mathrm{O}_{3}$ & $\mathrm{FeO}$ & $\mathrm{MnO}$ & $\mathrm{MgO}$ & $\mathrm{CaO}$ & $\mathrm{Na}_{2} \mathrm{O}$ & $\mathrm{K}_{2} \mathrm{O}$ & Total \\
\hline BR40A-1 & 22 & $\mathrm{~S}$ & 27.93 & 0.00 & 19.23 & 0.00 & 19.92 & 0.05 & 18.61 & 0.09 & 0.02 & 0.06 & 85.91 \\
\hline BR40A-1 & 23 & $\mathrm{~S}$ & 29.16 & 0.11 & 18.35 & 0.04 & 19.33 & 0.18 & 18.92 & 0.39 & 0.00 & 0.07 & 86.54 \\
\hline BR40A-1 & 24 & $\mathrm{~S}$ & 34.81 & 0.24 & 15.42 & 0.10 & 17.95 & 0.13 & 17.67 & 3.53 & 0.28 & 0.06 & 90.19 \\
\hline BR40A-1 & 25 & $\mathrm{R}$ & 27.68 & 0.06 & 20.01 & 0.05 & 18.64 & 0.13 & 20.08 & 0.12 & 0.07 & 0.01 & 86.84 \\
\hline BR40A-1 & 26 & $\mathrm{~S}$ & 28.32 & 0.06 & 19.54 & 0.04 & 17.62 & 0.18 & 20.12 & 0.10 & 0.03 & 0.03 & 86.03 \\
\hline BR40A-3 & 29 & $\mathrm{R}$ & 28.96 & 0.01 & 18.83 & 0.00 & 14.88 & 0.06 & 22.17 & 0.09 & 0.12 & 0.04 & 85.16 \\
\hline BR40B-1 & 39 & $\mathrm{R}$ & 28.74 & 0.06 & 18.44 & 0.20 & 18.73 & 0.05 & 20.31 & 0.12 & 0.16 & 0.10 & 86.90 \\
\hline BR40B-1 & 43 & $\mathrm{~S}$ & 28.91 & 0.14 & 18.69 & 0.22 & 17.10 & 0.11 & 20.85 & 0.10 & 0.09 & 0.00 & 86.22 \\
\hline BR40B-2 & 45 & $\mathrm{~S}$ & 28.03 & 0.06 & 18.99 & 0.05 & 18.09 & 0.13 & 20.01 & 0.12 & 0.02 & 0.02 & 85.51 \\
\hline BR40B-2 & 48 & $\mathrm{~S}$ & 29.47 & 0.06 & 18.06 & 0.05 & 14.75 & 0.19 & 23.24 & 0.12 & 0.09 & 0.00 & 86.01 \\
\hline BR40B-2 & 49 & $\mathrm{~S}$ & 29.93 & 0.08 & 18.25 & 0.05 & 15.57 & 0.00 & 22.71 & 0.02 & 0.01 & 0.00 & 86.62 \\
\hline BR40B-2 & 52 & $\mathrm{~S}$ & 34.51 & 0.00 & 13.62 & 0.23 & 14.44 & 0.10 & 18.98 & 2.57 & 0.25 & 0.03 & 84.74 \\
\hline BR40C-1-a & 8 & $\mathrm{~S}$ & 27.38 & 0.12 & 20.48 & 0.25 & 20.19 & 0.14 & 19.72 & 0.12 & 0.02 & 0.00 & 88.42 \\
\hline BR40C-1-a & 9 & $\mathrm{~S}$ & 30.43 & 0.10 & 17.04 & 0.26 & 18.71 & 0.00 & 19.29 & 0.63 & 0.07 & 0.08 & 86.60 \\
\hline BR40C-1-b & 10 & V & 27.01 & 0.07 & 20.06 & 0.00 & 18.62 & 0.17 & 19.75 & 0.22 & 0.02 & 0.03 & 85.94 \\
\hline BR 40C-1-b & 11 & V & 27.91 & 0.08 & 19.25 & 0.12 & 18.95 & 0.14 & 18.92 & 0.69 & 0.04 & 0.00 & 86.08 \\
\hline BR 40C-1-b & 15 & V & 27.11 & 0.03 & 19.54 & 0.10 & 19.56 & 0.21 & 19.13 & 0.14 & 0.04 & 0.06 & 85.92 \\
\hline BR40C-2 & 17 & $\mathrm{~S}$ & 27.85 & 0.02 & 19.66 & 0.05 & 20.11 & 0.16 & 19.10 & 0.11 & 0.00 & 0.00 & 87.06 \\
\hline BR40C-2 & 18 & $\mathrm{~S}$ & 27.49 & 0.01 & 20.19 & 0.13 & 20.14 & 0.19 & 18.76 & 0.11 & 0.00 & 0.03 & 87.06 \\
\hline BR40C-2 & 20 & $\mathrm{~S}$ & 27.88 & 0.10 & 19.52 & 0.00 & 20.44 & 0.22 & 19.18 & 0.10 & 0.01 & 0.03 & 87.47 \\
\hline BR40C-2 & 21 & V & 27.27 & 0.00 & 20.16 & 0.12 & 20.78 & 0.08 & 19.05 & 0.05 & 0.00 & 0.04 & 87.55 \\
\hline BR40C-3 & 25 & $\mathrm{~S}$ & 28.97 & 0.03 & 18.11 & 0.00 & 20.30 & 0.17 & 19.70 & 0.33 & 0.04 & 0.00 & 87.64 \\
\hline BR40E-4 & 21 & V & 27.41 & 0.07 & 19.16 & 0.00 & 21.01 & 0.13 & 17.95 & 0.02 & 0.03 & 0.00 & 85.77 \\
\hline BR40E-4 & 22 & V & 27.81 & 0.03 & 18.98 & 0.09 & 20.39 & 0.08 & 17.71 & 0.03 & 0.00 & 0.03 & 85.15 \\
\hline BR40E-4 & 23 & $\mathrm{~V}$ & 27.30 & 0.04 & 19.31 & 0.02 & 19.96 & 0.03 & 17.62 & 0.00 & 0.00 & 0.00 & 84.27 \\
\hline BR40E-1 & 26 & $\mathrm{~S}$ & 29.97 & 0.06 & 16.30 & 0.98 & 18.8 & 0 . & 19.11 & & 0. & 1 & 85.64 \\
\hline BR40E-1 & 30 & $\mathrm{~V}$ & 28.84 & 0.06 & 18.11 & 0.15 & 18.27 & 0.17 & 19.15 & 0.32 & 0.05 & 0.00 & 85.13 \\
\hline BR40E-1 & 31 & $\mathrm{~V}$ & 28.89 & 0.03 & 18.58 & 0.11 & 19.25 & 0.10 & 20.06 & 0.02 & 0.04 & 0.02 & 87.10 \\
\hline BR40E-1 & 34 & $\mathrm{~S}$ & 29.12 & 0.07 & 17.76 & 0.45 & 18.33 & 0.06 & 20.33 & 0.04 & 0.02 & 0.00 & 86.16 \\
\hline BR40E-1 & 35 & $\mathrm{~S}$ & 29.05 & 0.02 & 17.58 & & 18.75 & 0.06 & 19.57 & 0.08 & 0.05 & 0.00 & 85.63 \\
\hline BR40E-2 & 39 & $\mathrm{~S}$ & 29.30 & 0.00 & 17.03 & 1.31 & 19.36 & 0.17 & 19.80 & 0.13 & 0.04 & 0.06 & 87.17 \\
\hline BR40E-2 & 44 & $\mathrm{R}$ & 28.27 & 0.03 & 19.21 & 0.00 & 19.15 & 0.02 & 18.78 & 0.21 & 0.01 & 0.00 & 85.68 \\
\hline BR40E-2 & 45 & $\mathrm{R}$ & 27.46 & 0.05 & 20.21 & 0.11 & 20.83 & 0.12 & 18.17 & 0.09 & 0.06 & 0.02 & 87.13 \\
\hline BR40E-2 & 46 & $\mathrm{R}$ & 27.73 & 0.01 & 19.92 & 0.28 & 19.53 & 0.16 & 18.78 & 0.14 & 0.04 & 0.01 & 86.60 \\
\hline BR40E-3 & 47 & $\mathrm{R}$ & 27.77 & 0.08 & 19.03 & 0.01 & 20.03 & 0.03 & 18.20 & 0.02 & 0.03 & 0.00 & 85.19 \\
\hline BR40E-3 & 48 & $\mathrm{R}$ & 27.89 & 0.06 & 19.20 & 0.00 & 20.23 & 0.11 & 18.43 & 0.19 & 0.01 & 0.05 & 86.17 \\
\hline BR40E-3 & 50 & $\mathrm{~S}$ & 29.26 & 0.03 & 17.44 & & 17. & & 20. & 0 . & & 00 & 85.33 \\
\hline BR40E-3 & 52 & $\mathrm{C}$ & 29.02 & 0.03 & 17.54 & 0.21 & 16.56 & 0.11 & 20.91 & 0.01 & 0.00 & 0.04 & 84.43 \\
\hline BR40E-3 & 53 & $\mathrm{C}$ & 29.10 & 0.02 & 17.60 & 0.19 & 16.55 & 0.13 & 20.80 & 0.00 & 0.01 & 0.01 & 84.41 \\
\hline BR40E-3 & 54 & $\mathrm{C}$ & 30.87 & 0.03 & 17.02 & 0.22 & 17.59 & 0.12 & 20.84 & 0.87 & 0.02 & 0.01 & 87.58 \\
\hline BR71A-1 & 33 & $\mathrm{~S}$ & 30.49 & 0.05 & 18.56 & 0.06 & 12.54 & 0.00 & 24.53 & 0.15 & 0.00 & 0.00 & 86.37 \\
\hline BR71A-1 & 36 & $\mathrm{~S}$ & 30.41 & 0.00 & 18.00 & 0.10 & 12.18 & 0.02 & 23.95 & 0.43 & 0.01 & 0.04 & 85.14 \\
\hline BR71A-1 & 37 & $\mathrm{~S}$ & 30.74 & 0.04 & 18.09 & 0.00 & 11.86 & 0.19 & 24.33 & 0.38 & 0.00 & 0.01 & 85.64 \\
\hline BR71A-1 & 38 & $\mathrm{~S}$ & 31.42 & 0.12 & 16.98 & 0.11 & 11.94 & 0.08 & 23.94 & 0.46 & 0.00 & 0.03 & 85.08 \\
\hline BR71A-1 & 39 & $\mathrm{~S}$ & 30.99 & 0.08 & 17.59 & 0.05 & 11.94 & 0.03 & 23.83 & 0.49 & 0.00 & 0.04 & 85.03 \\
\hline BR71A-1 & 40 & $\mathrm{~S}$ & 30.49 & 0.08 & 17.60 & 0.08 & 11.93 & 0.10 & 23.49 & 0.46 & 0.00 & 0.00 & 84.24 \\
\hline BR71A-2 & 5 & $\mathrm{~S}$ & 30.10 & 0.04 & 18.79 & 0.13 & 12.55 & 0.09 & 23.15 & 0.14 & 0.01 & 0.03 & 85.02 \\
\hline BR71A-2 & 6 & $\mathrm{~S}$ & 30.12 & 0.11 & 18.57 & 0.00 & 12.44 & 0.02 & 22.62 & & & 0.01 & 84.01 \\
\hline BR71A-2 & 12 & $\mathrm{~S}$ & 30.86 & 0.05 & 17.28 & 0.13 & 13.64 & 0.00 & 22.73 & 0.33 & 0.03 & 0.03 & 85.08 \\
\hline BR71A-2 & 13 & $\mathrm{~S}$ & 30.24 & 0.03 & 17.98 & 0.09 & 13.78 & 0.16 & 22.91 & 0.17 & 0.02 & 0.02 & 85.39 \\
\hline BR71C-3 & 35 & $\mathrm{C}$ & 35.72 & 0.04 & 14.89 & 0.13 & 13.63 & 0.06 & 23.97 & 0.10 & 0.02 & 0.00 & 88.55 \\
\hline BR71C-3 & 36 & $\mathrm{C}$ & 38.23 & 0.04 & 14.00 & 0.00 & 13.05 & 0.07 & 24.16 & 0.09 & 0.03 & 0.00 & 89.66 \\
\hline BR71C-2 & 39 & $\mathrm{C}$ & 32.12 & 0.04 & 15.73 & 0.22 & 14.33 & 0.19 & 24.06 & 0.16 & 0.04 & 0.00 & 86.89 \\
\hline BR71C-1 & 48 & $\mathrm{~S}$ & 31.66 & 0.06 & 16.83 & 0.26 & 15.10 & 0.17 & 22.99 & 0.41 & 0.03 & 0.05 & 87.56 \\
\hline $86 \mathrm{~A}-1$ & 2 & $\mathrm{C}$ & 32.64 & 0.07 & 16.23 & 0.16 & 12.77 & 0.00 & 27.08 & 0.06 & 0.10 & 0.05 & 89.22 \\
\hline $86 \mathrm{~A}-1$ & 3 & $\mathrm{C}$ & 30.95 & 0.00 & 17.39 & 0.06 & 12.09 & 0.10 & 26.20 & 0.08 & 0.04 & 0.03 & 86.96 \\
\hline $86 \mathrm{~A}-1$ & 4 & $\mathrm{C}$ & 31.30 & 0.07 & 16.99 & 0.16 & 10.97 & 0.00 & 27.08 & 0.04 & 0.02 & 0.03 & 86.66 \\
\hline $86 \mathrm{~A}-2$ & 15 & $\mathrm{C}$ & 32.83 & 0.11 & 14.58 & 0.01 & 12.54 & 0.00 & 26.43 & 0.29 & 0.06 & 0.03 & 86.89 \\
\hline $86 \mathrm{~A}-2$ & 16 & $\mathrm{C}$ & 30.89 & 0.09 & 16.06 & 0.00 & 14.88 & 0.09 & 23.56 & 0.23 & 0.11 & 0.03 & 85.97 \\
\hline $86 \mathrm{~A}-2$ & 19 & $\mathrm{C}$ & 34.52 & 0.05 & 13.27 & 0.00 & 14.04 & 0.14 & 24.22 & 1.42 & 0.13 & 0.04 & 87.90 \\
\hline $86 \mathrm{~A}-2$ & 20 & $\mathrm{C}$ & 28.51 & 0.09 & 16.01 & 0.00 & 16.89 & 0.00 & 23.13 & 0.12 & 0.12 & 0.10 & 84.96 \\
\hline
\end{tabular}


Table A3. (continued)

\begin{tabular}{|c|c|c|c|c|c|c|c|c|c|c|c|c|c|}
\hline Sample & $\mathrm{IP}^{\mathrm{a}}$ & Mode ${ }^{b}$ & $\mathrm{SiO}_{2}$ & $\mathrm{TiO}_{2}$ & $\mathrm{Al}_{2} \mathrm{O}_{3}$ & $\mathrm{Cr} 2 \mathrm{O}_{3}$ & $\mathrm{FeO}$ & $\mathrm{MnO}$ & $\mathrm{MgO}$ & $\mathrm{CaO}$ & $\mathrm{Na}_{2} \mathrm{O}$ & $\mathrm{K}_{2} \mathrm{O}$ & Total \\
\hline $86 \mathrm{~A}-3$ & 24 & $\mathrm{~S}$ & 31.32 & 0.04 & 14.67 & 0.24 & 12.77 & 0.01 & 25.74 & 0.24 & 0.07 & 0.04 & 85.14 \\
\hline $86 \mathrm{~A}-3$ & 25 & S & 29.92 & 0.06 & 15.22 & 0.60 & 13.44 & 0.04 & 26.29 & 0.02 & 0.04 & 0.02 & 85.66 \\
\hline $86 A-3$ & 29 & S & 31.11 & 0.02 & 14.94 & 0.01 & 9.92 & 0.00 & 27.07 & 0.23 & 0.05 & 0.06 & 83.41 \\
\hline $86 A-3$ & 30 & S & 30.59 & 0.00 & 15.59 & 0.07 & 10.87 & 0.16 & 27.01 & 0.09 & 0.04 & 0.05 & 84.49 \\
\hline $86 \mathrm{~A}-4$ & 36 & S & 31.72 & 0.04 & 13.71 & 0.70 & 9.37 & 0.06 & 28.00 & 0.59 & 0.09 & 0.02 & 84.31 \\
\hline DR19-1-2 & 18 & $\mathrm{~S}$ & 37.95 & 0.00 & 12.13 & 0.27 & 9.06 & 0.06 & 27.38 & 0.11 & 0.06 & 0.00 & 87.03 \\
\hline DR19-1-2 & 20 & $\mathrm{~S}$ & 33.62 & 0.05 & 14.85 & 0.19 & 7.90 & 0.05 & 29.21 & 0.00 & 0.02 & 0.03 & 85.92 \\
\hline DR19-1-2 & 21 & $\mathrm{~S}$ & 40.66 & 0.00 & 10.58 & 0.10 & 8.75 & 0.04 & 28.21 & 0.06 & 0.05 & 0.01 & 88.45 \\
\hline DR19-1-3 & 25 & $\mathrm{~S}$ & 36.34 & 0.04 & 13.07 & 0.05 & 9.67 & 0.08 & 27.46 & 0.06 & 0.02 & 0.00 & 86.79 \\
\hline DR19-1-3 & 27 & $\mathrm{~S}$ & 35.89 & 0.08 & 15.20 & 0.01 & 4.97 & 0.04 & 30.06 & 0.10 & 0.04 & 0.01 & 86.40 \\
\hline DR19-1-3 & 28 & $\mathrm{~S}$ & 34.64 & 0.00 & 13.75 & 0.06 & 8.18 & 0.00 & 28.50 & 0.14 & 0.04 & 0.01 & 85.32 \\
\hline DR19-1-3 & 29 & $\mathrm{~S}$ & 35.20 & 0.00 & 13.83 & 0.09 & 7.75 & 0.20 & 29.06 & 0.06 & 0.00 & 0.01 & 86.21 \\
\hline DR19-1-3 & 30 & $\mathrm{~S}$ & 33.69 & 0.00 & 14.83 & 0.03 & 7.17 & 0.01 & 29.00 & 0.07 & 0.02 & 0.04 & 84.86 \\
\hline DR19-1-4 & 31 & $X$ & 32.53 & 0.02 & 13.26 & 1.87 & 7.87 & 0.10 & 29.63 & 0.09 & 0.05 & 0.04 & 85.45 \\
\hline DR19-1-4 & 32 & $X$ & 32.56 & 0.04 & 13.38 & 1.59 & 7.93 & 0.00 & 29.38 & 0.04 & 0.09 & 0.04 & 85.02 \\
\hline DR19-1-4 & 33 & $\mathrm{X}$ & 32.79 & 0.00 & 13.57 & 1.68 & 8.19 & 0.07 & 28.55 & 0.05 & 0.11 & 0.00 & 85.01 \\
\hline DR2-9-1 & 1 & V & 33.35 & 0.10 & 13.90 & 0.21 & 8.20 & 0.07 & 30.19 & 0.03 & 0.00 & 0.00 & 86.05 \\
\hline DR26-3-1 & 34 & $X$ & 35.27 & 0.08 & 13.25 & 0.15 & 5.11 & 0.03 & 31.79 & 0.12 & 0.02 & 1.11 & 86.92 \\
\hline DR26-3-1 & 39 & $X$ & 34.39 & 0.01 & 12.79 & 0.02 & 4.78 & 0.04 & 32.08 & 0.13 & 0.01 & 0.12 & 84.37 \\
\hline
\end{tabular}

${ }^{\mathrm{a}}$ Probe analysis number.

${ }^{\mathrm{b}} \mathrm{S}$, Matrix of shear zone; C, Clast; V, Veins; R, Radial chlorite; X, Static chloritization.

Table A4. Whole Rock Major and Rare Earth Analyses ${ }^{\mathrm{a}}$

\begin{tabular}{|c|c|c|c|c|c|c|c|c|c|c|c|}
\hline Sample & DR13-23 & DR13-17 & DR14-5 & DR02-8 & DR26-8 & DR22-2 & BR40-2 & BR63-4 & BR40-3 & BR28-1 & BR71-5 \\
\hline Type & $\begin{array}{l}\text { Talc } \\
\text { schist }\end{array}$ & serpentine & serpentine & serpentine & diabase & diabase & $\begin{array}{l}\text { Talc } \\
\text { schist }\end{array}$ & $\begin{array}{l}\text { Talc } \\
\text { schist }\end{array}$ & $\begin{array}{l}\text { Amphibolite } \\
\text { schist }\end{array}$ & $\begin{array}{l}\text { Amphibolite } \\
\text { schist }\end{array}$ & $\begin{array}{l}\text { Amphibolite } \\
\text { schist }\end{array}$ \\
\hline $\mathrm{SiO}_{2}$ & 60.04 & 38.52 & 38.47 & 39.51 & 43.03 & 45.41 & 57.68 & 57.22 & 42.14 & 49.89 & 45.08 \\
\hline $\mathrm{Al}_{2} \mathrm{O}_{3}$ & 0.62 & 0.91 & 0.81 & 1.16 & 18.08 & 16.53 & 1.28 & 0.5 & 9.1 & 4.3 & 7.73 \\
\hline $\mathrm{Fe}_{2} \mathrm{O}_{3}$ & 4.24 & 9.73 & 8.08 & 7.44 & 13.39 & 10.21 & 4.42 & 4.59 & 13.87 & 9.65 & 10.66 \\
\hline $\mathrm{MnO}$ & $<$ D.L. & 0.03 & 0.05 & 0.03 & 0.25 & 0.22 & 0.03 & 0.06 & 0.12 & 0.09 & 0.1 \\
\hline $\mathrm{MgO}$ & 29.8 & 37.77 & 38.15 & 38.32 & 9.02 & 10.44 & 28.92 & 24.9 & 20.09 & 21.21 & 24.85 \\
\hline $\mathrm{CaO}$ & $<$ D.L. & $<$ D.L. & 0.46 & $<$ D.L. & 9.03 & 10.51 & 2.78 & 9.8 & 6.57 & 9.99 & 2.95 \\
\hline $\mathrm{Na}_{2} \mathrm{O}$ & 0.13 & 0.16 & 0.1 & 0.14 & 2.3 & 2.07 & 0.14 & 0.29 & 0.36 & 0.2 & 0.39 \\
\hline $\mathrm{K}_{2} \mathrm{O}$ & $<$ D.L. & $<$ D.L. & $<$ D.L. & $<$ D.L. & $<$ D.L. & $<$ D.L. & $<$ D.L. & $<$ D.L. & $<$ D.L. & $<$ D.L. & $<$ D.L. \\
\hline $\mathrm{TiO}_{2}$ & $<$ D.L. & $<$ D.L. & $<$ D.L. & $<$ D.L. & 1.46 & 1.14 & $<$ D.L. & $<$ D.L. & 0.55 & $<$ D.L. & 0.57 \\
\hline $\mathrm{P}_{2} \mathrm{O}_{5}$ & 0.05 & 0.05 & 0.06 & 0.05 & 0.18 & 0.12 & $<$ D.L. & $<$ D.L. & 0.05 & $<$ D.L. & 0.11 \\
\hline $\mathrm{PF}$ & 5.16 & 12.82 & 13.92 & 13.62 & 3.66 & 3.18 & 4.77 & 2.59 & 6 & 4.07 & 7.52 \\
\hline Total & 100.04 & 99.99 & 100.1 & 100.27 & 100.4 & 99.83 & 100.02 & 99.95 & 98.850 & 99.40 & 99.96 \\
\hline $\mathrm{Cl}(\mathrm{ppm})$ & 515 & 1470 & 1065 & 1295 & 79 & 490 & $<$ D.L & $<$ D.L & $<$ D.L & $<$ D.L & $<$ D.L \\
\hline $\mathrm{La}(\mathrm{ppm})$ & 0.081 & 0.333 & 0.199 & 0.056 & 4.87 & 4.22 & 0.068 & 0.571 & 1.349 & 0.211 & 1.695 \\
\hline $\mathrm{Ce}(\mathrm{ppm})$ & 0.094 & 0.515 & 0.565 & 0.172 & 13.99 & 11.21 & 0.185 & 1.906 & 5.345 & 0.835 & 5.814 \\
\hline $\operatorname{Pr}(\mathrm{ppm})$ & 0.022 & 0.079 & 0.093 & 0.026 & 2.02 & 1.70 & $<$ D.L & 0.317 & 0.893 & 0.138 & 0.914 \\
\hline $\mathrm{Nd}(\mathrm{ppm})$ & 0.09 & 0.321 & 0.471 & 0.127 & 10.35 & 8.55 & 0.12 & 1.66 & 4.785 & 0.84 & 4.714 \\
\hline $\mathrm{Sm}$ (ppm) & 0.027 & 0.075 & 0.148 & 0.056 & 3.35 & 2.80 & 0.041 & 0.464 & 1.564 & 0.361 & 1.473 \\
\hline $\mathrm{Eu}(\mathrm{ppm})$ & 0.005 & 0.038 & 0.022 & 0.022 & 1.66 & 1.23 & 0.019 & 0.234 & 0.51 & 0.148 & 0.592 \\
\hline Gd (ppm) & 0.033 & 0.087 & 0.176 & 0.07 & 4.11 & 3.41 & 0.046 & 0.472 & 1.889 & 0.632 & 1.778 \\
\hline $\mathrm{Tb}(\mathrm{ppm})$ & 0.006 & 0.014 & 0.032 & 0.014 & 0.68 & 0.58 & 0.012 & 0.071 & 0.317 & 0.121 & 0.301 \\
\hline Dy (ppm) & 0.046 & 0.108 & 0.25 & 0.103 & 4.54 & 3.84 & 0.067 & 0.449 & 2.097 & 0.948 & 2.035 \\
\hline Ho (ppm) & 0.01 & 0.025 & 0.061 & 0.025 & 1.00 & 0.84 & 0.014 & 0.07 & 0.43 & 0.212 & 0.419 \\
\hline $\operatorname{Er}(\mathrm{ppm})$ & 0.028 & 0.072 & 0.173 & 0.073 & 2.70 & 2.37 & 0.049 & 0.185 & 1.207 & 0.66 & 1.197 \\
\hline Tm (ppm) & 0.005 & 0.014 & 0.03 & 0.014 & 0.42 & 0.36 & 0.014 & 0.07 & 0.43 & 0.212 & 0.419 \\
\hline $\mathrm{Yb}(\mathrm{ppm})$ & 0.034 & 0.106 & 0.202 & 0.103 & 2.74 & 2.33 & 0.056 & 0.105 & 1.1 & 1.1 & 1.243 \\
\hline $\mathrm{Lu}(\mathrm{ppm})$ & 0.006 & 0.018 & 0.031 & 0.018 & 0.42 & 0.36 & 0.009 & 0.011 & 0.17 & 0.199 & 0.19 \\
\hline
\end{tabular}

${ }^{\mathrm{a}}$ D.L., Detection limit. 
we propose that the detachment fault soled out in the shallow, cold lithosphere, possibly at the alteration front. The detachment was active below the ridge axis and during periods of magmatic activity, as indicated by the presence of both diabase intrusions into the fault zone and highly deformed diabases within the fault schists. This detachment model may be applicable to the corrugated and striated surfaces found along the Mid-Atlantic Ridge and other slow- and intermediate-spreading ridges.

[62] Detachments may also develop in the presence of active magmatism at the ridge axis, as observed at the Atlantis II Bank. This second type of detachment is also active during magmatism and roots in the shallow lithosphere, but soles out in a melt rich zone (possibly the gabbro-dyke transition). The detachment morphology, the occurrence and relative abundance of lithologies, and the deformation processes recorded by the footwall rocks differ substantially from one type of detachment to the other. In both cases, however, the detachments are active in the presence of magmatism, confirming that amagmatic extension is not required for detachment faulting in the oceanic lithosphere.

\section{Appendix A: Major Element Analyses of Spinel, Amphibole and Chlorite, and Whole-Rock Major and Rare Earth Element Analyses}

[63] In appendix A we report both mineral and whole rock analyses of selected samples (see Tables 1 and 2 for sample locations). The major element analyses of spinel are given in Table A1, those of amphiboles in Table A2, and those of chlorite in Table A3. Whole rock analyses of both major and rare earth elements are given in Table A4.

\section{Acknowledgments}

[64] We are grateful to great work of the Captain and the Crew of the RRS James Clark Ross, the British Geological Survey Drill Team, the TOBI Team (SOC, UK), and the JR63 Scientific Party, who made possible the success of the cruise. Discussions with the JR63 Scientific Party during the cruise, and with M. Cannat and J. Casey, contributed ideas to the paper. Comments by Roger Searle, Barbara John, an anonymous reviewer and the Associate Editor C. Chauvel helped to clarify and improve the manuscript. This work is partially supported by a CNRS/NERC "Egide" grant to J. Escartín and C. J. MacLeod. GMT software [Wessel and Smith, 1991] was extensively used in this project. This is IPGP Contribution number 1913 and Cardiff School of Earth, Ocean and Planetary Sciences contribution number 4 .

\section{References}

Allen, D. E., and W. E. Seyfried, Compositional controls on vent fluids from ultramafic systems at mid-ocean ridges: An experimental study at $400^{\circ} \mathrm{C}, 500$ bars, Geochim. Cosmochim. Acta, 67, 1531-1542, 2003.

Allerton, S., D. Wallis, J. Derrick, D. Smith, and C. J. MacLeod, New wireline seafloor drill augers well, Eos Trans. $A G U, 80,367,1999$.

Anderson, J. L., A. P. Barth, and E. D. Young, Mid-crustal Cretaceous roots of Cordilleran metamorphic core complexes, Geology, 16, 366-369, 1988.

Blackman, D. K., J. R. Cann, B. Janssen, and D. K. Smith, Origin of extensional core complexes: Evidence from the Mid-Atlantic Ridge at Atlantis Fracture Zone, J. Geophys. Res., 103, 21,315-21,333, 1998.

Brun, J. P., D. Sokoutis, and J. Van Den Driessche, Analogue modeling of detachment fault systems and core complexes, Geology, 22, 319-322, 1994.

Buck, R. W., Flexural rotation of normal faults, Tectonics, 7, 959-973, 1988.

Bykerk-Kauffman, A., and S. U. Janecke, Late Cretaceous to early Tertiary ductile deformation: Catalina-Rincon metamorphic core complex, southeastern Arizona, Geology, 15, 569-572, 1987.

Campbell-Stone, E. A., B. E. John, J. W. Geissman, D. A. Foster, and R. Livicarri, Mechanisms for accommodation of Miocene extension: Low-angle normal faulting, magmatism, and secondary breakaway faulting in the southern Sacramento Mountains, southeastern California, Tectonics, 19, 566-587, 2000.

Cann, J. R., D. K. Blackman, D. K. Smith, E. McAllister, B. Janssen, S. Mello, E. Avgerinos, A. R. Pascoe, and J. Escartín, Corrugated slip surfaces formed at North Atlantic ridge-transform intersections, Nature, 385, 329-332, 1997.

Cannat, M., Emplacement of mantle rocks in the seafloor at mid-ocean ridges, J. Geophys. Res., 98, 4163-4172, 1993.

Cannat, M., and J. F. Casey, An ultramaphic lift at the MidAtlantic Ridge: Successive stages of magmatism in serpentinized peridotites from the $15^{\circ} \mathrm{N}$ region, in Mantle and Lower Crust Exposed in Oceanic Ridges and in Ophiolites, edited by R. L. M. Vissers and A. Nicolas, pp. 5-34, Kluwer Acad., Norwell, Mass., 1995.

Cannat, M., D. Bideau, and H. Bougault, Serpentinized peridotites and gabbros in the Mid-Atlantic Ridge axial valley at $15^{\circ} 37^{\prime} \mathrm{N}$ and $16^{\circ} 52^{\prime} \mathrm{N}$, Earth Planet. Sci. Lett., 109, 87-106, 1992.

Cannat, M., Y. Lagabrielle, H. Bougault, J. Casey, N. de Coutures, L. Dmitriev, and Y. Fouquet, Ultramafic and gabbroic exposures at the Mid-Atlantic Ridge: Geological mapping in the $15^{\circ} \mathrm{N}$ region, Tectonophysics, 279, 193-213, 1997. 
Casey, J. F., M. G. Braun, and P. B. Kelemen, Megamullions along the mid-Atlantic ridge between $14^{\circ} \mathrm{N}$ and $16^{\circ} \mathrm{N}$ : Results of Leg 1, JAMSTEC/WHOI MODE 98 Survey, Eos Trans. $A G U$, 79(46), Fall Meet. Suppl., F920, 1998.

Christie, D. M., B. P. West, and D. G. Pyle, Extreme morphologic and petrologic diversity within the Southeast Indian Ridge (abstract), Eos Trans. AGU, 78(46), Fall Meet. Suppl., F673, 1997.

Collins, J., and R. S. Detrick, Seismic structure of the Atlantis Fracture Zone megamullion, a serpentinized ultramafic massif, Eos Trans. AGU, 79(46), Fall Meet. Suppl., F800, 1998.

Davis, G. H., Shear-zone model for the origin of metamorphic core complexes, Geology, 11, 342-347, 1983.

Davis, G. H., and G. S. Lister, Detachment faulting in continental extension: Perspectives from the southwestern U.S. Cordillera, in Processes in continental lithosphere deformation, edited by S. P. Clark Jr. et al., Geol. Soc. Am. Spec. Pap., 218, 133-160, 1988.

Deplus, C., J. Escartín, A. Briais, M. Cannat, J. Georgen, J. Lin, S. Mercouriev, C. Meyzen, M. Muller, G. Pouliquen, A. Rabain, and P. da Silva, Linking variation in magma supply and segment growth: Temporal evolution of segment OH-1(MAR at $\left.35^{\circ} \mathrm{N}\right)$, Eos Trans. $A G U, 79(46)$, Fall Meet. Suppl., F856, 1998.

Detrick, R. S., J. Escartín, and H. Nouzé, In situ seismic velocity structure of gabbros and ultramafics exposed at shallow crustal levels in the Mid-Atlantic Ridge rift valley at 1520`N (abstract), Geophys. Res. Abstr., 1, 186, 1999.

Dick, H. J. B., and T. Bullen, Chromian spinel as a petrogenic indicator in abyssal and alpine-type peridotites and spatially associated lavas, Contrib. Mineral. Petrol., 86, 54-76, 1984.

Dick, H. J. B., H. Schouten, P. S. Meyer, D. G. Gallo, H. Bergh, R. Tyce, P. Patriat, K. T. M. Johnson, J. Snow, and A. Fischer, Tectonic evolution of the Atlantis II Fracture Zone, Proc. Ocean Drill. Program Sci. Results, 118, 359398, 1991.

Dick, H. J. B., J. H. Natland, and D. J. Miller, Proc. Ocean Drill. Program Initial Rep., Leg 176, vol. 176, Ocean Drilling Program, College Station, Tex., 1999.

Dick, H. J. B., et al., Along in situ section of the lower oceanic crust: Results of ODP Leg 176 drilling at the Southwest Indian Ridge, Earth Planet. Sci. Lett., 179, 31-51, 2000.

Dick, H. J. B., T. Matsumoto, B. John, H. Kinoshita, P. Robinson, G. Hirth, J. Natland, and C. J. MacLeod, The Atlantis Bank Core complex, paper presented at InterRidge SWIR Workshop, Southampton, U.K., 2002.

Dosso, L., H. Bougault, J. G. Schilling, and J.-L. Joron, Sr-Nd$\mathrm{Pb}$ geochemical morphology between $10^{\circ}$ and $17^{\circ} \mathrm{N}$ on the Mid-Atlantic Ridge: A new MORB isotope signature, Earth Planet. Sci. Lett., 106, 29-43, 1991.

Dosso, L., H. Bougault, and J.-L. Joron, Geochemical morphology of the North Mid-Atlantic Ridge, $10^{\circ}-24^{\circ} \mathrm{N}$ : Trace element-isotope complementary, Earth Planet. Sci. Lett., 120, 443-462, 1993.

Ernst, W. G., and J. Liu, Experimental phase-equilibrium study of Al- and Ti-contents of calcic amphibole in MORB-A semiquantitative thermobarometer, Am. Mineral., 83, 952969, 1998.
Escartín, J., and M. Cannat, Ultramafic exposures and the gravity signature of the lithosphere near the Fifteen-Twenty Fracture Zone (Mid-Atlantic Ridge, $14^{\circ}-16.5^{\circ} \mathrm{N}$ ), Earth Planet. Sci. Lett., 171, 411-424, 1999.

Escartín, J., G. Hirth, and B. Evans, Non-dilatant brittle deformation of serpentinites: Implications for Mohr-Coulomb theory and the strength of faults, J. Geophys. Res., 102, $2897-$ 2913, 1997a.

Escartín, J., G. Hirth, and B. Evans, Effects of Serpentinization on the Lithospheric Strength and the Style of Normal Faulting at Slow-Spreading Ridges, Earth Planet. Sci. Lett., 151, 181-190, 1997b.

Escartín, J., G. Hirth, and B. Evans, Strength of slightly serpentinized peridotites: Implications of the tectonics of oceanic lithosphere, Geology, 29, 1023-1026, 2001.

Fletcher, J. M., J. M. Bartley, M. W. Martin, A. Z. Glazner, and J. D. Walker, Large-magnitude continental extension: An example from the Central Mojave Desert, Geol. Soc. Am. Bull., 107, 1468-1483, 1995.

Fujiwara, T., P. B. Kelemen, M. G. Braun, M. Joshima, J. F. Casey, A. Takeuchi, and G. M. Ceuleneer, Bathymetry, geomagnetic and gravity anomalies of the Mid-Atlantic Ridge between $14^{\circ} \mathrm{N}$ and $16^{\circ} \mathrm{N}$, Eos Trans. $A G U$, 80(46), Fall Meet. Suppl., F956, 1999.

Fujiwara, T., J. Lin, T. Matsumoto, P. B. Kelemen, B. E. Tucholke, and J. F. Casey, Crustal Evolution of the MidAtlantic Ridge near the Fifteen-Twenty Fracture Zone in the last $5 \mathrm{Ma}$, Geochem. Geophys. Geosyst., 4(3), 1024, doi:10.1029/2002GC000364, 2003.

Gartell, A. P., Evolution of rift basins and low-angle detachments in multilayer analog models, Geology, 25, 615-618, 1997.

Holland, T., and J. Blundy, Non-ideal interactions in calcic amphiboles and their bearing on amphibole-plagioclase thermometry, Contrib. Mineral. Petrol., 116, 433-447, 1994.

Jackson, J. A., and N. J. White, Normal faulting in the upper continental crust: Observations from regions of active extension, J. Struct. Geol., 11, 15-36, 1989.

Jaroslow, G. E., H. J. B. Dick, and G. Hirth, Abyssal peridotite mylonites: Implications for grain-size sensitive flow and strain partitioning in the oceanic lithosphere, Tectonophysics, 256, 17-37, 1996.

John, B., Geometry and evolution of a mid-crustal extension fault system: Chemeuevi Mountains, southeastern California, in Continental Extensional Tectonics, edited by M. P. Coward, J. F. Dewey, and P. L. Hancock, pp. 313-335, Geol. Soc., London, 1987.

Karson, J., Geological investigation of a lineated massif at the Kane Transform: Implications for oceanic core complexes, Philos. Trans. R. Soc. London, 357, 713-740, 1999.

Kelley, D. S., et al., An off-axis hydrothermal vent field near the Mid-Atlantic Ridge at $30^{\circ} \mathrm{N}$, Nature, 411, 145-149, 2001.

Lagabrielle, Y., D. Bideau, M. Cannat, J. A. Karson, and C. Mével, Ultramafic-mafic plutonic rock suites exposed along the Mid-Atlantic Ridge $\left(10^{\circ} \mathrm{N}-30^{\circ} \mathrm{N}\right)$. Symmetricalasymmetrical distribution and implications for seafloor spreading processes, in Faulting and Magmatism at Mid- 
Ocean Ridges, Geophys. Monogr. Ser., vol. 106, edited by W. R. Buck et al., pp. 153-176, AGU, Washington, D. C., 1998.

Lavier, L., W. R. Buck, and A. N. B. Poliakov, Self-consistent rolling-hinge model for the evolution of large-offset lowangle normal faults, Geology, 27, 1127-1130, 1999.

Lee, J., and G. S. Lister, Late Miocene ductile extension and detachment faulting, Mykonos, Greece, Geology, 20, $121-$ 124, 1992.

Lehnert, K., Y. Su, C. H. Langmuir, B. Sarbas, and U. Nohl, A global geochemical database structure for rocks, Geochem. Geophys. Geosyst., 1, Paper number 1999GC000026, 2000.

Lister, G. S., and S. L. Baldwin, Plutonism and the origin of metamorphic core complexes, Geology, 21, 607-610, 1993.

Lister, G. S., G. Banga, and A. Feenstra, Metamorphic core complexes of Cordilleran type in the Cyclades, Aegean Sea, Greece, Geology, 12, 221-225, 1984.

MacLeod, C. J., et al., Geological mapping of slow-spread lower ocean crust: A deep-towed video and wireline rock drilling survey of Atlantis Bank (ODP Site 735, southwest Indian Ridge), InterRidge News, 7, 39-43, 1998.

MacLeod, C. J., et al., RRS James Clark Ross cruise JR63 Cruise Report, 59 pp., Cardiff Univ., Wales, 2001.

MacLeod, C. J., et al., Direct geological evidence for oceanic detachment fauling: The Mid-Atlantic Ridge, $15^{\circ} 45^{\prime} \mathrm{N}$, Geology, 30, 10, 879-882, 2002.

Martinez, F., J. Karsten, and E. M. Klein, Recent kinematics and tectonics of the Chile Ridge, Eos Trans. AGU, 79(46), Fall Meet. Suppl., F836, 1998.

Matsumoto, T., and P. B. Kelemen, Precise geological and geophysical mapping of the $15^{\circ} 20^{\prime} \mathrm{N}$ Fracture Zone on the MAR - Tectonic extension and its consequent exposure of ultramafic and plutonic rocks along the magma-poor ridge axis (MODE'98 Leg 1 Cruise), InterRidge News, 7, 13-17, 1998.

Mével, C., M. Cannat, P. Gente, E. Marion, J. M. Auzende, and J. A. Karson, Emplacement of deep crustal and mantle rocks on the west median valley wall of the MARK area (MAR, 23N), Tectonophysics, 190, 31-53, 1991.

Miller, E. L., P. B. Gans, and J. Garing, The Snake Range décollement: An exhumed mid-Tertiary ductile-brittle transition, Tectonics, 2, 239-263, 1983.

Mitchell, N. C., J. Escartín, and S. Allerton, Detachment faults at Mid-Ocean Ridges garner interest, Eos Trans. AGU, 79, 127, 1998.

Miyashiro, A., Metamorphism and Metamorphic Belts, John Wiley, New York, 1973.

Moore, D., D. A. Lockner, M. Shengli, R. Summers, and J. D. Byerlee, Strength of serpentinite gouges at elevated temperatures, J. Geophys. Res., 102, 14,787-14,801, 1997.

Mueller, K. J., and A. W. Snoke, Progressive overprinting of normal fault systems and their role in Tertiary exhumation of the East Humboldt-Wood Hills metamorphic complex northeast Nevada, Tectonics, 12, 361-371, 1993.

Mulugeta, G., and W. Ghebreab, Modeling heterogeneous stretching during episodic or steady rifting of the continental lithosphere, Geology, 29, 895-898, 2001.
Natland, J. H., and H. J. B. Dick, Formation of the lower oceanic crust and the crystallization of gabbroic cumulates at a very slowly spreading ridge, J. Volcanol. Geotherm. Res., 110, 191-233, 2001.

O'Hanley, D. S., Solution to the volume problem in serpentinization, Geology, 20, 705-708, 1992.

O’Hanley, D. S., Serpentinites, 277 pp., Oxford Univ. Press, New York, 1996.

Parsons, T., and G. A. Thompson, Does magmatism influence low-angle normal faulting?, Geology, 21, 247-250, 1993.

Passchier, C. W., and R. A. J. Trouw, Micro-tectonics, 289 pp., Springer-Verlag, New York, 1998.

Ranero, C., and T. J. Reston, Detachment faulting at ocean core complexes, Geology, 27, 983-986, 1999.

Reinen, L. A., J. D. Weeks, and T. E. Tullis, The frictional behavior of serpentinite: Implications for aseismic creep on shallow crustal faults, Geophys. Res. Lett., 18, 1921-1924, 1991.

Reston, T. J., W. Weinrebe, I. Grevemeyer, N. C. Flueh, L. Kirstein, C. Kopp, H. Kopp, and M. Participants, A rifted inside corner massif on the Mid-Atlantic Ridge at $5^{\circ} \mathrm{S}$, Earth Planet. Sci. Lett., 200, 255-269, 2002.

Robinson, P. T., et al. (Eds.), Proc. Ocean Drill. Program, Initial Reports, vol. 118, 826 pp., Ocean Drilling Program, College Station, Tex., 1989.

Schroeder, T., B. John, and B. R. Frost, Geologic implications of seawater circulation through peridotite exposed at slow-spreading mid-ocean ridge, Geology, 30, 367-370, 2002.

Searle, R. C., H. Fujioka, M. Cannat, C. Mevel, H. Fujimoto, and L. M. Parson, FUJI Dome, a large detachment fault near 64 degrees E on the very slow spreading South West Indian Ridge (abstract), EOS Trans. $A G U, 80(46)$, Fall Meet. Suppl., F956, 1999.

Shaw, P. R., Ridge segmentation, faulting and crustal thickness in the Atlantic Ocean, Nature, 358, 490-493, 1992.

Smith, W. H., and D. T. Sandwell, Global seafloor topography from satellite altimetry and ship depth soundings, Science, 227, 1956-1962, 1997.

Spencer, J. E., Role of tectonic denudation in warping and uplift of low-angle normal faults, Geology, 12, 95-98, 1984.

Spencer, J. E., Geologic continuous casting below continental and deep-sea detachment faults and the striated extrusion of Sacsayhuamán, Perú, Geology, 27, 327-330, 1999.

Tamaki, K., and C. Mével, Spreading tectonics of the eastern part of the Southwestern Indian Ridge: A synthesis of FUJI expedition (abstract), Eos Trans. AGU, 79(46), Fall Meet. Suppl., F892, 1998.

Tucholke, B. E., J. Lin, and M. C. Kleinrock, Megamullions and mullion structure defining oceanic metamorphic core complexes on the Mid-Atlantic Ridge, J. Geophys. Res., 103, 9857-9866, 1998.

Tucholke, B. E., J. Lin, M. C. Kleinrock, M. Tivey, T. B. Reed, J. Goff, and G. E. Jaroslow, Segmentation and crustal structure of the western Mid-Atlantic Ridge flank, $25^{\circ} 25^{\prime}-$ $27^{\circ} 10^{\prime} \mathrm{N}$ and 0-29 m. y., J. Geophys. Res., 102, 10,20310,223, 1997. 
Tucholke, B. E., K. Fujioka, T. Ishihara, G. Hirth, and M. Kinoshita, Submersible study of an oceanic megamullion in the central North Atlantic, J. Geophys. Res., 106, 16,14516,161, 2001.

Wernicke, B., Low-angle normal faults in the Basin and Range province: Nappe tectonics in an extending orogen, Nature, 291, 645-648, 1981.

Wernicke, B., The fluid crustal layer and its implications for continental dynamics, in Exposed Cross Sections of the Continental Crust, edited by M. Salisbury and D. M. Fountain, pp. 509-544, Kluwer, Norwell, Mass., 1990.
Wernicke, B., and G. J. Axen, On the role of isostasy in the evolution of normal fault systems, Geology, 16, 848-851, 1988.

Wessel, P., and W. H. F. Smith, Free software helps map and display data, Eos Trans. AGU, 72, 441, 445-446, 1991.

Wright, L. A., B. W. Troxell, E. G. Williams, M. T. Roberts, and P. E. Diehl, Precambrian sedimentary environments of the Death Valley region, California and Nevada, in Guidebook, Death Valley Region, California and Nevada, pp. 27-36, Death Valley Publ., Shoshone, Calif., 1974. 